\title{
Sedimentary basin analysis of the
}

continental Devonian basin in

\section{North-East Greenland}

G E U S

Report file no.

22320

Henrik Olsen

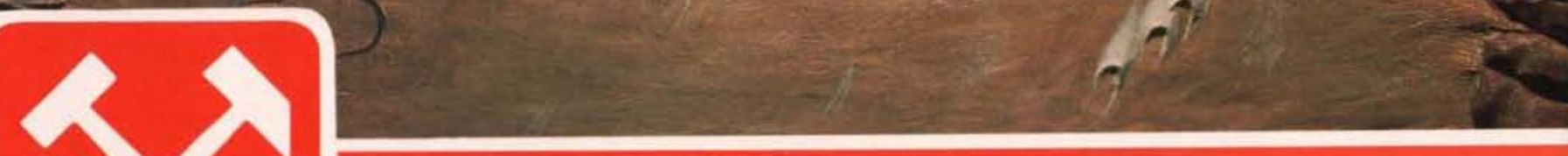

GRØNLANDS GEOLOGISKE UNDERSØGELSE

GGU Bulletin 168 


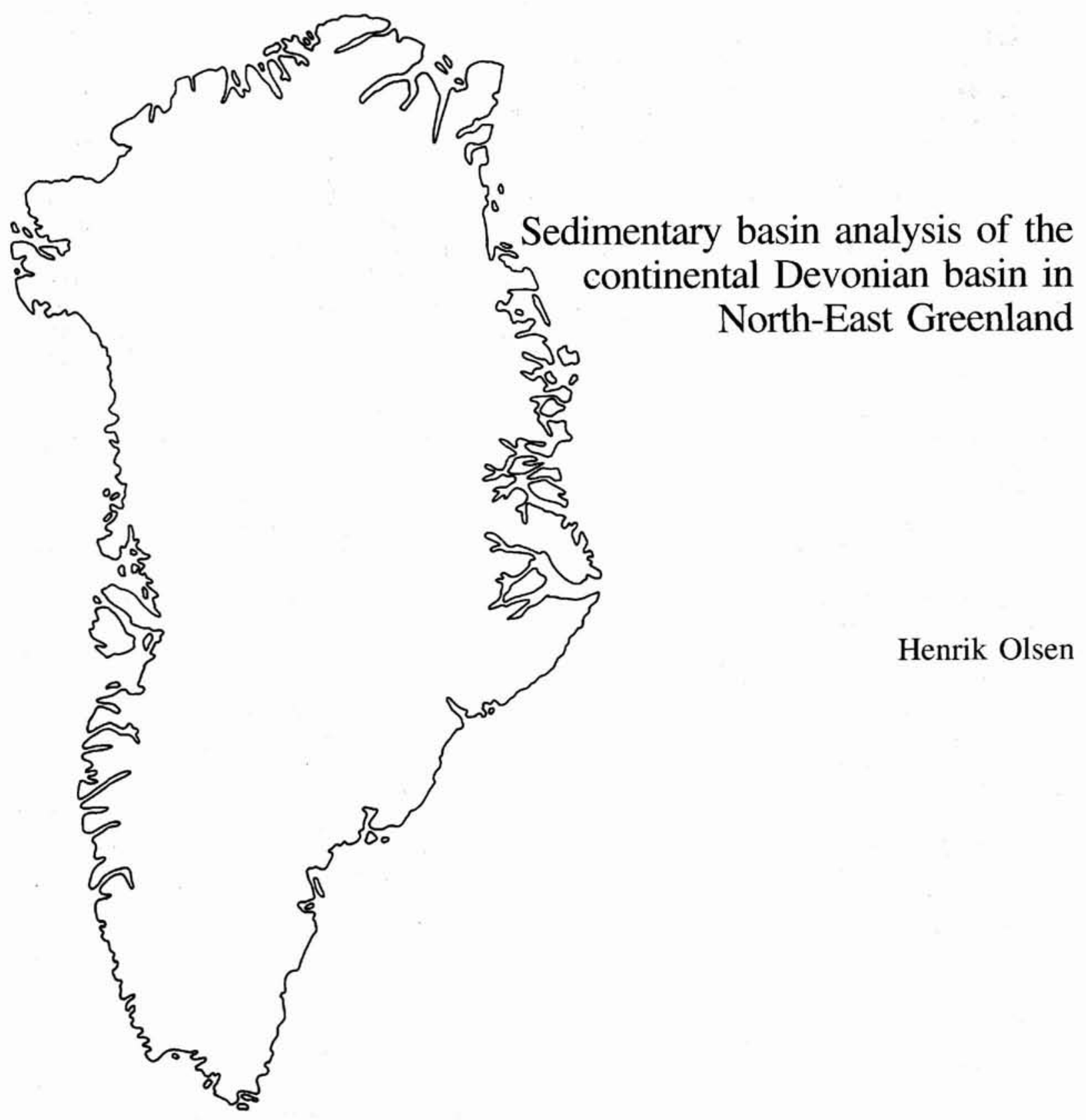


Olsen, H. 1993: Sedimentary basin analysis of the continental Devonian basin in North-East Greenland. Bull. Grønlands geol. Unders. 168, 80 pp.

Continental Devonian sediments attain a stratigraphic thickness in excess of $8000 \mathrm{~m}$ in North-East Greenland. Four tectonostratigraphic basin stages are recognized in the succession defined by drainage patterns and bounding unconformities and named according to their constituent lithostratigraphic units. The oldest Vilddal basin stage exhibits eastward drainage, the succeeding Kap Kolthoff - Kap Graah basin stage exhibits southward drainage, northward drainage characterizes the Celsius Bjerg basin stage, and southwestward drainage is characteristic of the youngest Harder Bjerg basin stage.

The Middle Devonian Vilddal stage developed after the Caledonian orogeny, when extensional deformation took place in East and North-East Greenland associated with subordinate sinistral strike-slip. An oblique-slip fault zone developed along the western boundary of the Vilddal stage basin, the so-called Western Fault Zone. A major fault scarp was established, but the main sediment input into the basin occurred along synthetic faults, oblique to the strike of the fault zone. Sediment dispersal in general was towards the east. No eastern basin margin occurred within the area of present-day exposures. The Vilddal Group attains a thickness of approximately 2500 $\mathrm{m}$. Initially gravelly braided rivers dominated the palaeogeography; later sandy and silty depositional systems prevailed, mainly fluvial but also lacustrine in the downcurrent eastern part of the basin. During this late depositional phase of the Vilddal stage the climate changed regularly from relatively wet to relatively dry, giving rise to alternating green and red sediments.

A new era is represented by the Middle-Upper Devonian Kap Kolthoff - Kap Graah basin stage indicating that a basin margin was established along the Eastern Fault Zone close to the eastern boundary of the basin exposed today. Deposition of the up to $2700 \mathrm{~m}$ thick Kap Kolthoff Group was dominated by a sandy braid plain, draining southwards with inputs from both east and west. Throughout deposition of the Kap Kolthoff Group tectonism strongly influenced deposition. During several periods drainage was locally affected by tectonism resulting in local reduction of discharge and development of terminal fans and aeolian dune fields. The Kap Graah Group is c. $1300 \mathrm{~m}$ thick and represents a climatic deterioration. Initially a basin-wide erg was developed and fluvial deposition almost ceased. After a prolonged dry period a gradual increase in discharge occurred associated with intense structural deformation of the basin interior, and hinterland uplift. The discharge increase resulted in progradation of basin-margin alluvial systems and the establishment of an axial meandering river, draining southwards. The river exhibited systematic variations in size and discharge, supposedly corresponding to cyclic climatic variations.

The Upper Devonian Celsius Bjerg stage was initiated by a drainage reversal caused by compressional tectonics (strike/oblique-slip) and uplift of the southern part of the basin. The Celsius Bjerg Group (up to $1550 \mathrm{~m}$ thick) reflects a transgression of the Eastern Fault Zone but the position of the basin margin was still close to this fault zone. The position of the depocentre was strongly controlled by structural deformation of the basin. Climate also played an important role, and during a prolonged dry period an ephemeral lake complex dominated the palaeogeography. Alluvial systems, however, formed the most important palaeogeomorphic basin elements, all draining in a general northward direction. At the end of the Celsius Bjerg stage a basin-wide permanent lake was developed under humid climatic conditions, possibly combined with a tectonic damming event which closed an existing basinal outlet.

The final stage in the evolution of the basin is represented by the Harder Bjerg basin stage of unknown age. Very limited investigations were carried out on the patchy exposures of the up to $200 \mathrm{~m}$ thick Harder Bjerg Formation, but drainage seems to be directed towards the southwest. Both fluvial and aeolian conditions are reflected, and a relatively dry climate is envisaged.

\section{Author's address:}

Instituttet for Geologi og Geoteknik, Bygning 204, Danmarks Tekniske Højskole, DK-2800 Lyngby, Denmark.

\section{Cover picture}

The Devonian basin in North-East Greenland is dominated by alluvial systems. In this reconstruction from complex 5 in the Kap Kolthoff - Kap Graah basin stage, marginal alluvial fan and terminal fan systems occur in association with an axial meandering river system. Patches of aeolian sand sheets and dunes are also observed. The model is reproduced by courtesy of the Geological Museum, Copenhagen. 


\section{Contents}

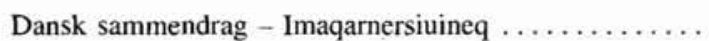

Introduction . . . . . . . . . . . . . . . . . . . . .

Previous work and recent investigations ..........

Basin evolution . . . . . . . . . . . . . . . . . .

Facies associations $\ldots \ldots \ldots \ldots \ldots \ldots \ldots \ldots \ldots$

Depositional systems. . . . . . . . . . . . . . .

Depositional complexes ................... 8

Tectonostratigraphic basin stages ............ 8

Underlying controls. . . . . . . . . . . . . . 9

Vilddal basin stage: eastward draining alluvial plains . 9

Depositional complex $1 \ldots \ldots \ldots \ldots \ldots \ldots . \ldots$

Depositional complex $2 \ldots \ldots \ldots \ldots \ldots \ldots \ldots, 11$

Underlying controls.................. 13

Kap Kolthoff - Kap Graah basin stage: southward draining alluvial plains and associated aeolian systems ........................... 17

Depositional complex $3 \ldots \ldots \ldots \ldots \ldots \ldots . \ldots \ldots$

Depositional complex $4 \ldots \ldots \ldots \ldots \ldots \ldots . \ldots 24$

Depositional complex $5 \ldots \ldots \ldots \ldots \ldots \ldots . \ldots 26$

Underlying controls................... 28

Celsius Bjerg basin stage: northward draining alluvial plains and lakes......................... 31

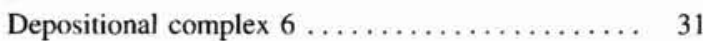

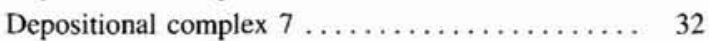

Depositional complex $8 \ldots \ldots \ldots \ldots \ldots \ldots . \ldots \ldots \ldots$

Depositional complex $9 \ldots \ldots \ldots \ldots \ldots \ldots . \ldots . \ldots 34$

Depositional complex $10 \ldots \ldots \ldots \ldots \ldots \ldots . \ldots . \ldots . \ldots 35$

Underlying controls................... 35

Harder Bjerg basin stage: southwestward draining alluvial plains and associated aeolian systems ....... 38

Comparison with early ideas of basin evolution..... 38

Summary of the basin evolution ............ 40

Regional tectonic and climatic framework ....... 41

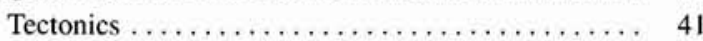

Climate $\ldots \ldots \ldots \ldots \ldots \ldots \ldots \ldots \ldots \ldots \ldots, 41$

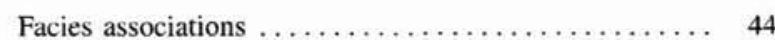

Aeolian dune association $\ldots \ldots \ldots \ldots \ldots \ldots \ldots .44$

General characteristics .................. 44

Previous investigations ................. 45

Details .......................... 45

Aeolian sand sheet/interdune association......... 49

General characteristics .................... 49

Previous investigations ................ 51

Details ........................... 51

Flood basin association................ 53

General characteristics ................ 53

Previous investigations ............... 53

Details ........................ 53

Ephemeral stream association............ 57

General characteristics ................. 57

Previous investigations ................ 57

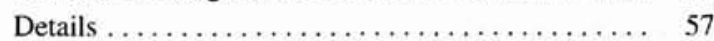

Meandering river association $\ldots \ldots \ldots \ldots \ldots \ldots, 60$

General characteristics .................. 60

Previous investigations................. 60

Details ............................ 60

Sandy braided river association $\ldots \ldots \ldots \ldots \ldots \ldots 63$

General characteristics ................. 63

Previous investigations ................ 63

Details ........................... 63

Gravelly stream association .............. 67

General characteristics .................. 67

Previous investigations ................. 67

Details .......................... 67

Lacustrine association. ................ 72

General characteristics ................ 72

Previous investigations ................ 72

Details ........................... 73

Acknowledgements ....................... 74

References.......................... 75

\section{Grønlands Geologiske Undersøgelse Ujarassiortut Kalaallit Nunaanni Misissuisoqarfiat Geological Survey of Greenland}

The Geological Survey of Greenland (GGU) is a research institute affiliated to the Mineral Resources Administration for Greenland (MRA) within the Danish Ministry of Energy. As with all other activities involving the non-living resources in Greenland. GGU's investigations are carried out within the framework of the policies decided jointly by the Greenland Home Rule Authority and the Danish State. 


\section{Dansk sammendrag}

En sedimentologisk bassinanalyse af det mellem-øvre devone kontinentale aflejringsbassin i Nordøstgrønland er blevet udført i forbindelse med 3 ekspeditioner til området (1986-88). Undersøgelserne bygger hovedsageligt på vertikal opmåling (målestok 1:5000) af $\mathrm{i}$ alt ca. 27 kilometer lagfølger fordelt på 34 lokaliteter. Opmålingerne er baseret på en inddeling af sedimenterne i 8 faciesassociationer, som afspejler aflejring fra klitter, vindsletter/interklitområder, flodsletter, kortlivede vandløb, mæandrerende floder, sandede flettede floder, grusede vandløb, og søer.

Kortlægning af den vertikale og laterale fordeling af facies-associationer har gjort det muligt at definere en række aflejringssystemer, som er kædet sammen i bassinskala aflejringskomplekser. Bassinfyldet på i alt godt 8 km er inddelt i 11 aflejringskomplekser, og kompleksgrænserne repræsenterer 'eventstratigrafiske' begivenheder af tektonisk eller klimatisk art. Aflejringskomplekserne kan inddeles i fire overordnede tektonostratigrafiske bassin-stadier; Vilddal stadiet, Kap Kolthoff - Kap Graah stadiet, Celsius Bjerg stadiet og Harder Bjerg sta- diet, opkaldt efter de lithostratigrafiske enheder, som opbygger bassinfyldet.

De fire tektonostratigrafiske bassin-stadier er defineret ved dræneringsmønstre og begrænsende diskordansflader. De aflejringskomplekser, som tilhører samme tektonostratigrafiske bassin-stadium, udviser fælles generelle dræneringsmønstre, som adskiller sig fra dræneringsmønstre i de tilstødende tektonostratigrafiske bassin-stadier. De begrænsende flader mellem bassin-stadierne udgøres af sub-regionale til bassinskala diskordanser, mens der internt $\mathrm{i}$ bassin-stadierne kun forekommer lokale diskordanser.

Vilddal bassin-stadiet udgøres af mellem devone aflejringer, som afspejler østgående drænering. Kap Kolthoff - Kap Graah bassin-stadiet opbygges af mellem$\emptyset$ vre devone aflejringer og er defineret ved generelt sydgående drænering. Det øvre devone Celsius Bjerg bassinstadium er defineret ved generelt nordgående drænering, mens Harder Bjerg bassin-stadiet af ukendt alder defineres af sydvestlig drænering.

\section{Imaqarnersiuineq}

Imartorumarngit kinnganernik sunik immerneqarsimanerinik misissuineq Tunup avannaani nunavissuaq kinnganernik Devonip Akulliup-Qalliullu nalaani kiviorarfiusimasoq 1986-miit 1988-mut aasaanerani ingerlanneqartarsimavoq. Kinnganerit qaleriiaat qanoq qummut ammullu issutiginersut misissuisarnerni pingaarnerusutut uuttortarneqarsimapput (uuttuut 1:5000 atorlugu). Piffinnilu 34-ni kinnganerit qaleriiaat ataatsimut katillugit 27 kilometerit missaannik issussusillit uuttortarneqarsimallutik. Uuttortaanermi kinnganerit pinngorfigisarsimasaat tunngavigalugit arfineq pingasunut immikkoortinneqarsimapput. Immikkoortinneqartut tassaasimapput sioqqat ippinnguussimasut, narsaamanerit anorimit pinngorsimasut, kuunni narsaamarngit naqqorissut, kuut kuukitsut, kuut sangujoraartut, kuut siorallit perlaajatut isikkullit, kuut ujaraarallit tatsillu.

Nuna assiliornermi kinnganerit pinngorfigisimasaat assingiinngitsut qanoq issutiginerat isorartutiginerallu na- joqqutaralugu kinnqanerit sumi qangalu pinngorsimanerat nassuiarneqarsinnaalersimavoq. Imartorumanersuaq $8 \mathrm{~km}$-nik itissuseqartoq aqqanilinnut immikkoortinneqarsimavoq, immikkoortullu taakku nunavissuarmi sunik pisoqarsimaneranik imaluunniit silap qanoq issimaneranik nassuiapput. Kiviorarsimanerit pingaarnernut pingasunut immikkoortinneqarsinnaapput; Vilddal stadiet, Kap Kolthoff - Kap Graah stadiet aamma Celsius Bjerg stadiet, tassa kinnganerit imartorumanersuarmut piorartut sunik akoqarnerat tunngavigalugu.

Vilddal-ip nalaani kinnganerit kangimut ingerlanneqarsimapput Devonillu Akulliup nalaani kiviorarsimallutik. Kap Kolthoff - Kap Graah nalaani kinnganerit Devonip Akulliup-Qalliup nalaani kiviorarsimapput kujammullu ingerlanneqarsimallutik. Celsius Bjerg-imi Devonip Qalliup nalaani kiviorarsimasut avannamut ingerlanneqarsimapput. 


\section{Introduction}

The Devonian intramontane basin in North-East and East Greenland (Fig. 1) was initiated in the Middle Devonian in response to $\mathrm{E}-\mathrm{W}$ extensional tectonics and associated N-S sinistral strike-slip deformation (Larsen \& Bengaard, 1991). A more than $8 \mathrm{~km}$ thick succession of clastic sediments was deposited in late Middle and Late Devonian (Friend et al., 1983; Olsen \& Larsen, 1993a) and underwent a series of deformations both during and after deposition (Bütler, 1935a,b). The sediments generally rest unconformably on Cambro-Ordovician carbonates and, to a lesser extent, on older rocks in the northeastern part of the basin (Larsen, 1990a; Olsen \& Larsen, 1993a). Towards the east the sediments are generally in fault contact with Upper Palaeozoic and Mesozoic rocks. The main part of the exposed Devonian basin is situated in North-East Greenland with small outliers in Canning Land and on Wegener Halvø in East Greenland (Fig. 1A). Seismic studies from Jameson Land indicate the presence of deeply buried Devonian sediments in that area (H. C. Larsen et al., 1989).

A basin analysis, which commenced in 1986, has revealed a coherent picture of the sedimentary basin evolution. The main purpose of the present contribution is to present a comprehensive review of the basin evolution based on the documentation of depositional systems, their spatial distribution and systematic change through time. A major development in facies and depositional system analysis has occurred since the latest sedimentological field investigations were performed in the late 1960s and early 1970 s, and these methods have been applied to the present study. Of significant importance new concepts of event-stratigraphy and tectonostratigraphy have been used to unravel the complex depositional history of the basin. This study has been carried out as part of a joint structural-sedimentary basin analysis (Larsen \& Olsen, 1991) and has benefitted from detailed mapping and tectonic studies.

The bulletin is divided into two parts. The first part is an analysis of the basin evolution in an event- and tectonostratigraphic framework and forms the conclusive part of the bulletin. The backbone of this study is, however, the documentation and mapping of sedimentary facies associations. Thirty-four facies association logs, covering c. 27 kilometres of vertical profiles were measured in the field at a scale of 1:5000. The documentation of facies associations was made by detailed facies logs, generally at a scale of 1:50, measured in characteristic intervals of the studied successions. A total of $c .1300 \mathrm{~m}$ detailed logs was measured. The documentation of facies associations recognized in the Devonian succession is provided in the second part of the paper.

\section{Previous work and recent investigations}

Geological research during the first $30-40$ years of this century in the Devonian succession in North-East and East Greenland was focussed mainly on palaeontology and stratigraphy (e.g. Woodward, 1900; Kulling, 1930, 1931; Säve-Söderbergh, 1932a, 1932b, 1933, 1934, 1935; Stensiö, 1931, 1934, 1940). Important structural and lithostratigraphic contributions were later provided by Bütler (1935a, 1935b, 1954, 1955, 1957, 1959, 1961) and summarized by Haller (1971). In the period 1968-1970 three expeditions were carried out in the Devonian basin, led by P. F. Friend for the University of Cambridge and the sedimentology of the succession was extensively studied adding many new aspects to the understanding of the basin (Friend, 1978; Friend et al., 1976a, b, 1983; Alexander-Marrack \& Friend, 1976; Nicholson \& Friend, 1976; Yeats \& Friend, 1978). Based on the stratigraphic division by Bütler $(1959,1961)$, Friend et al. (1983) further subdivided the Devonian succession into a number of formal lithostratigraphic units. A more detailed historic review of Devonian research is provided in Olsen \& Larsen (1993a).

The most recent field investigations were carried out in connection with GGU expeditions in 1986, 1987 and 1988 (Marcussen et al., 1987, 1988; P.-H. Larsen et al., 1989). Integrated structural-sedimentary basin studies were restricted to the main Devonian outcrop belt in North-East Greenland. Structural geology studies and mapping were made by P.-H. Larsen (1990a,b,c,d; Fig. 1B) whereas the author of this bulletin was responsible for the sedimentological investigations, covering the main part of the exposed basin (Fig. 1A). The structural geology studies were also combined with mapping of the Caledonides by H.-J. Bengaard and resulted in a new tectonic model for the initiation of the basin (Larsen \& Bengaard, 1991). The integrated sedimentological studies and mapping of stratigraphic units resulted in a comprehensively revised lithostratigraphy of the Devonian succession (Fig. 2; Olsen \& Larsen, 1993a). Aspects of the sedimentology and the interplay of climate, tectonics and sedimentation have been presented elsewhere (Olsen, 1990, 1993; Larsen \& Olsen, 1991; Kelly \& Olsen, 1993; Olsen \& Larsen, 1993b). In 1987 a palaeontological expedition was mounted (Bendix-Almgreen et al., 1988) for investigation of the tetrapod fauna, which is the oldest 

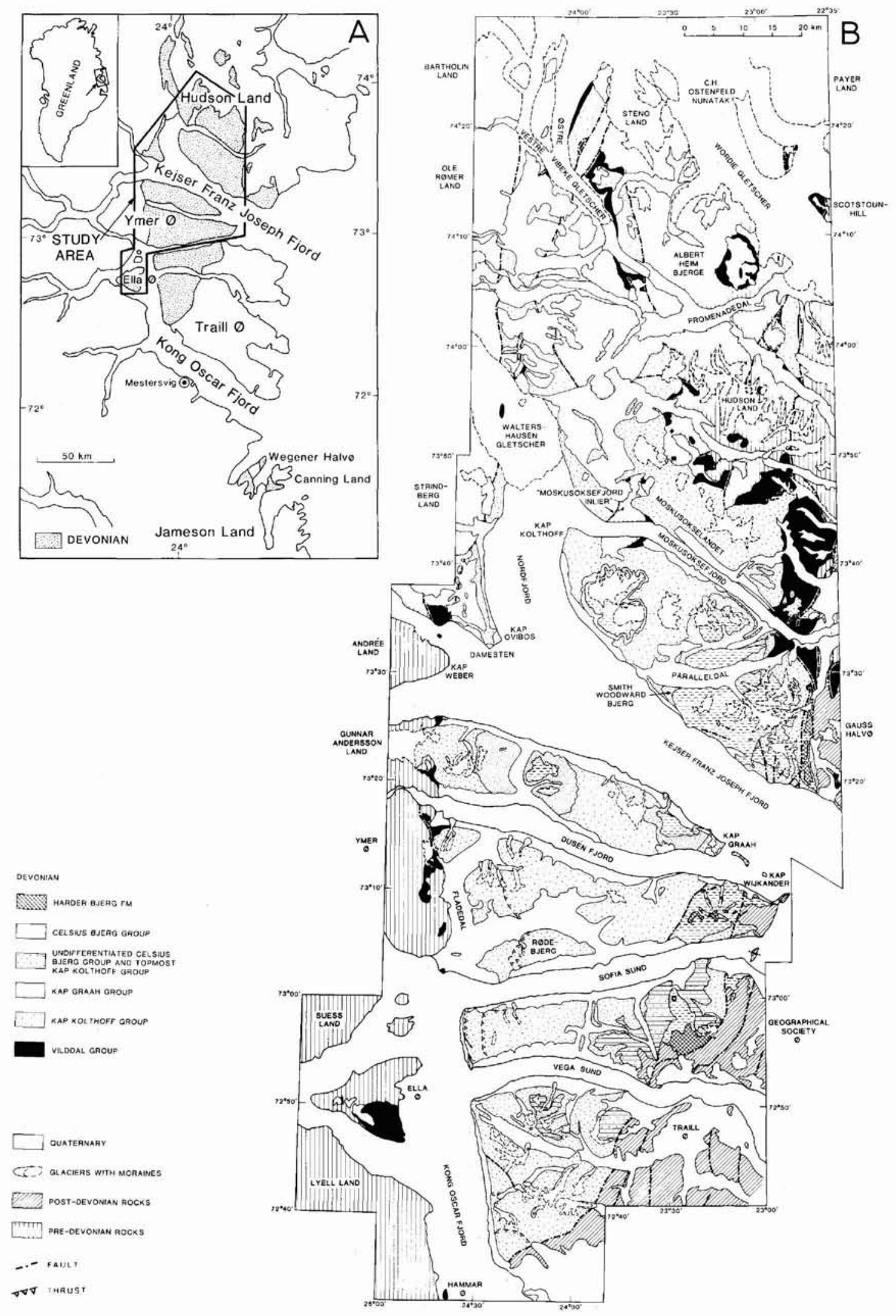

Fig. 1. Outcrops of Devonian sediments in North-East and East Greenland. (A) Indication of the main study area for the sedimentological investigations. Areas outside this area were only briefly visited by the author. (B) Geological map of the Devonian basin; from Olsen \& Larsen (1993a) and based on Larsen (1990a). 


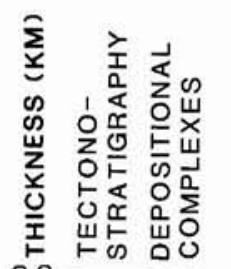

DEVONIAN LITHOSTRATIGRAPHY

$$
8.3
$$$$
\text { 8.3. }
$$

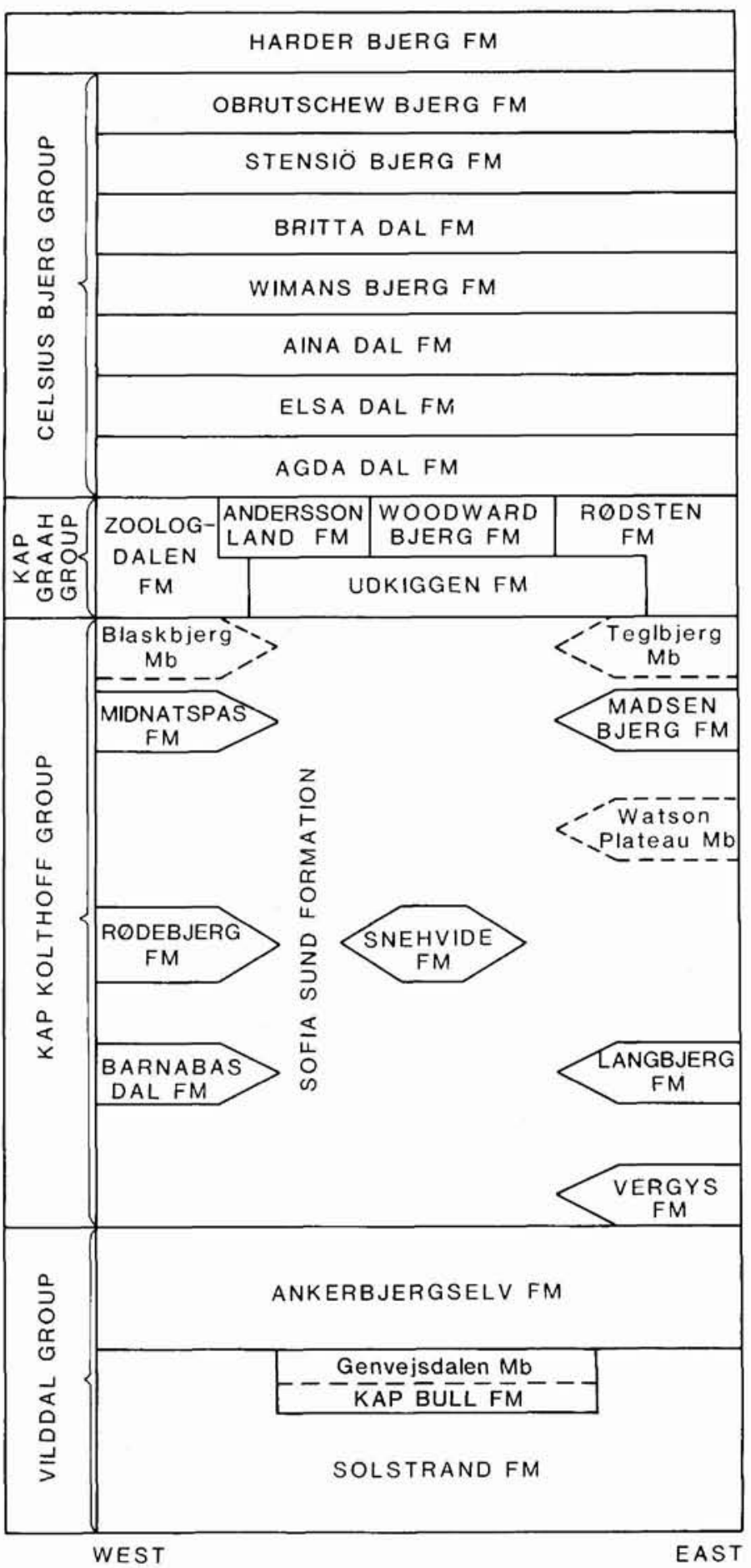

8.1 I क 11
6.5

5.

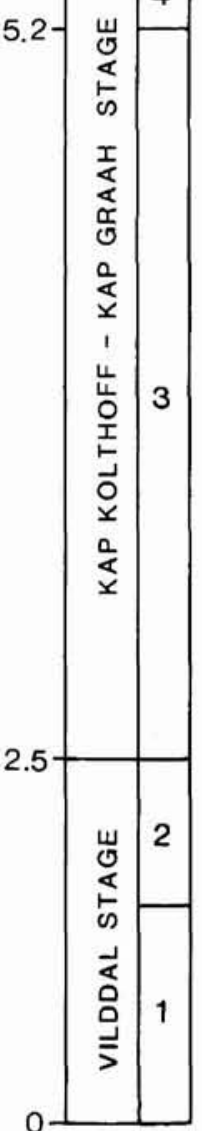

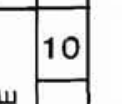

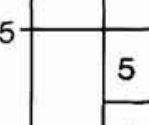

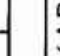


known in the world. The findings of well preserved tetrapods led to detailed palaeontological and palaeoec- ological studies of these earliest (partly) land-living vertebrates (Clack, 1989; Bendix-Almgreen et al., 1990).

\section{Basin evolution}

The main purpose of this bulletin is to outline the sedimentary basin evolution with respect to palaeogeography, climate and tectonics. The basin analysis is carried out in four scales represented by facies associations at the lowest level and depositional systems, depositional complexes and tectonostratigraphic basin stages at successively higher levels.

\section{Facies associations}

Eight facies associations are defined in the Devonian succession: aeolian dune, aeolian sand sheet/interdune, flood basin, ephemeral stream, meandering river, braided river, gravelly stream and lacustrine association (Table 1). Detailed documentation of the facies associations is provided in part two of this paper.

\section{Depositional systems}

A depositional system analysis (cf. Fischer \& McGowen, 1967; Brown \& Fischer, 1977; Miall, 1981, 1984, 1990; Galloway, 1989) has been carried out based on palaeocurrents and distribution of facies associations. Depositional systems are defined as three-dimensional assemblages of process-related facies associations which record major palaeogeomorphic basin elements (cf. Galloway, 1989), i.e. a meander belt, a terminal fan, an erg etc. In general, individual depositional systems were mappable on a subregional scale (tens of kilometres) on the basis of lithological changes. The majority of depositional systems are therefore defined as lithostratigraphic formations (Fig. 2). Successions with regular alternation on a metre to 10-metres scale of different depositional systems, which could only rarely be correlated from outcrop to outcrop, are, however, also assigned to a single formation (e.g. Ankerbjergselv Formation). Lateral lithological transitions are accepted within formations and depositional systems if they reflect proximal/distal/latero-distal variations within coherent depositional systems.

\section{Depositional complexes}

Depositional complexes are basin-wide in extent, composed of one or several depositional systems and bounded by event-stratigraphic surfaces. In the absence of high-resolution biostratigraphy, the definition of event-stratigraphic surfaces is solely based on sedimentological criteria; i.e. marked changes in depositional systems in the entire basin. Usually depositional complexes are linkages of contemporaneous depositional systems that record the basin-scale palaeogeography. Surfaces bounding depositional complexes are generally sharp and interpreted to reflect tectonic events or rapid changes in climate. Successive depositional systems sharing the same palaeocurrent pattern and many facies characteristics are also regarded as one complex. Thick successions in which no internal basin-wide surfaces of eventstratigraphic significance can be distinguished may be regarded as entire complexes if changes in the palaeogeography occur locally while the overall palaeogeography is maintained, or when two types of depositional systems regularly alternate. The complexes are numbered in ascending order from 1 to 11 (Fig. 2).

\section{Tectonostratigraphic basin stages}

Four tectonostratigraphic basin stages have been recognized in the Devonian succession. The basin fills of each stage are bounded by sub-regional (tens of kilometres) to basin-wide unconformities and represent depositional episodes punctuated by major tectonic events. Each basin stage is built up of depositional complexes sharing roughly similar drainage patterns, measured on a basin-wide scale. A tectonostratigraphic basin stage, accordingly, may be categorized as a higher order depositional complex. The basin stages almost coincide with the lithostratigraphic subdivision of the succession into groups. The first basin stage is represented by the Vilddal Group, the second basin stage is represented by the Kap Kolthoff and Kap Graah Groups, collectively, whereas the Celsius Bjerg Group represents the third basin stage. The basin stages are therefore named in accordance with these lithostratigraphic names (Fig. 2). The fourth basin stage, the Harder Bjerg stage, is represented by the Harder Bjerg Formation, which does not form part of any lithostratigraphic group. 


\section{Underlying controls}

Allocyclic controls on deposition is addressed for individual complexes and basin stages. A set of guidelines for the interpretation of underlying controls has been used:

(1) Basin-wide changes in drainage direction are considered tectonic in origin. Such changes probably reflect regional change in the tectonic regime. Commonly these changes in drainage pattern are associated with the development of unconformities, strongly supporting the tectonic interpretation.

(2) Local changes in drainage direction are also observed, commonly associated with progradation or lateral migration of one depositional system into an area previously occupied by another system. When the change in drainage direction is associated with local variations in the thickness of the depositional complex, a tectonic subsidence control is envisaged. When no subsidence control is observed, both a climatic and a tectonic explanation may be sought for. Increased precipitation in local parts of the surrounding areas would probably cause an expansion of some drainage systems at the expense of other drainage systems. Such local climatic changes are, however, most likely controlled by local tectonic uplift in the surrounding areas. Tectonic rejuvenation and development of steeper slopes would also cause increased discharge and release of material, which could result in progradation of marginal alluvial systems (e.g. Steel \& Wilson, 1975; Gloppen \& Steel, 1981). An alternative explanation is put forward by Heward (1978) and Blair (1987a). They suggest that progradation of basin-margin alluvial fans mainly occurs when rate of drainage-basin erosion and alluvial fan deposition surpass the tectonic subsidence rate. Thus progradation would be a product of tectonic quiescence. In contrast, longitudinal river systems and lakes would respond more quickly than alluvial fans and migrate to the basin-margin depression during periods of active subsidence at the expense of the alluvial fans (Blair, 1987a). The preferred explanation will be discussed in each case.

(3) Basin-wide changes in types of depositional systems from e. g. perennial streams to ephemeral streams or aeolian environments (and vice versa) are interpreted in terms of regional climatic changes affecting the precipitation rate in the entire drainage basins.

(4) Local changes of a similar kind as described in (3) are explained by local tectonism. A local tectonic event in the source terrain may cause a reduction in the size of drainage area along a segment of the basin and expansion of drainage area at other segments (Frostick \& Reed, 1987). Accordingly, local changes in the type of depositional system would occur.

In consequence of the intramontane nature of the basin (Friend et al., 1983), sea level fluctuations are disregarded as direct controls on palaeogeography and basin evolution, although major sea level changes may have had indirect control (see later).

In the review of the basin evolution and in the second part of the paper, numerous place names are used; a table of place names with an accompanying geographic map is therefore provided (Fig. 3).

\section{Vilddal basin stage: eastward draining alluvial plains}

The Vilddal basin stage (Givetian) comprises the oldest sediments in the Devonian basin and is represented by the $2500 \mathrm{~m}$ thick Vilddal Group. This is dominated by alluvial deposition, characterized by generally eastward drainage. The group unconformably overlies pre-Devonian sediments, mainly of Cambro-Ordovician age. Two depositional complexes built up this stage (Fig. 2). The lower complex 1 is dominated by gravelly alluvial depositional systems, whereas complex 2 is composed of mainly sandy and silty alluvial systems (Fig. 4). A basinwide unconformity and a general change in drainage towards south indicates the transition to the succeeding Kap Kolthoff - Kap Graah basin stage.

\section{Depositional complex 1}

Depositional complex 1 is composed of two depositional systems, represented by the Solstrand and the Kap Bull Formations with the Solstrand Formation dominant (Fig. 4).

The Solstrand Formation is basin-wide in extent. The depositional system is dominated by channel-shaped conglomerates and conglomerate sheets of the gravelly stream association with subordinate sandy braided river, ephemeral stream and flood basin deposits (Fig. 4). Generally the lowermost $50-90 \%$ of the formation is almost exclusively composed of conglomerates.

The main part of the Solstrand Formation represents a gravelly braid plain draining eastward into an alluvial plain of sandy braided rivers associated with flood basins or lakes in the distal part. The thick succession of conglomerates at Solstrand (Fig. 4, section 1) is closely related to a NW-SE trending, subvertical fault, hinged in NW and with downthrow to NE (Larsen \& Bengaard, 1991). The conglomerates on Ella $\varnothing$ are probably also associated with a similar fault type. The gravelly rivers 
Facies association

Acolian dune association

Aeolian sand sheet/interdune association

Flood basin association

Ephemeral stream association

Meandering river association

Sandy braided river association
Well-sorted fine, medium and coarse sandstones. Cross-bedded in sets 0.1-20 $\mathrm{m}$ thick, mainly trough shaped. Often $>25^{\circ}$ dip of cross-strata. Sandflow and climbing translatent strata.

Dominated by well-sorted fine sandstones. Flat and low-angle $\left(<15^{\circ}\right) \mathrm{clim}$ bing translatent strata (dominant). Medium to coarse-grained wind-ripple form sets. Irregular lamination. Wave-ripple form sets. Rootlets, burrows and desiccation cracks.

Interbedded mudstones, siltstones (dominant) and very fine to fine sandstones. Mud/siltstones: horizontal lamination, cross-lamination, brecciated bedding, bioturbation, apparently massive bedding, desiccation cracks. Sandstones: discrete $\mathrm{dm}$ thick sheets (dominant) and channel-shaped. Horizontal lamination, festoon cross-bedding, cross-lamination, scour-and-fills, rootlets.

Dominated by very fine to medium sandstones. Commonly associated with mudstones. Three main sediment bodies: (1) Aggraded broad channel-shaped sandstone bodies with cross-bedding, 0.1-2 $\mathrm{m}$ thick (dominant).

(2) Decimetre thick tabular sandstone sheets dominated by horizontal lamination and cross-lamination.

(3) Channel-shaped coarse siltstones and fine sandstones, usually less than $1 \mathrm{~m}$ thick, with lateral accretion bedding dominated by cross-lamination. Desiccation cracks are common in mudstones within and between sediment bodies. Rip-up clasts of mud are common.

Dominated by fine to medium sandstones. Tabular, single and multistorey sandstone bodies, $1.5-15 \mathrm{~m}$ thick, with lateral accretion bedding. Trough crossbedding (dominant), parallel lamination, cross lamination. Intra-clasts of mud common.

Dominated by fine to very coarse sandstones, rare conglomerates. Trough cross-bedding is dominant (dm-scale sets). Subordinate structures are trough to planar wedge-shaped cross-bedding ( $\mathrm{m}$-scale sets) and parallel lamination. Occur in broad channel-shaped or sheetlike storeys, generally 3-6 m thick. Extraformational pebbles common, intra-clasts rare.
Barchans, barchanoid dunes and compound (transverse to oblique) dunes with superimposed barchanoid dunes.

Aeolian sand sheets and interdunes, dominated by wind ripples in fine sand. Starved coarser ripples common. Frequent wet (wave ripples) and damp conditions (irregular lamination formed by adhesion ripples).

Flood basin and crevasse splays.

Mudstones and siltstones were deposited mainly from suspension in flood basins which were commonly subaerially exposed.

Sandstones were deposited mainly as unchannellized crevasse splays and more rarely in crevasse channels.

(1) Channellized low-sinuosity ephemeral streams.

(2) Sheetfloods.

(3) Channellized meandering ephemeral streams.

The channels and sheetfloods were generally shallow $(<1-2 \mathrm{~m})$

Meandering perennial rivers. Deposition on sandy point bars (lateral accretion bedding). Channel depth usually several metres.

Sandy braided perennial rivers. Deposition mainly by dunes, probably forming downstream accreting macroforms. Macroforms occasionally exhibited avalanche leesides (solitary planar wedge-shaped cross-sets). Lateral accretion locally common. Channel depth usually 3-6 m.

Sweet et al. (1988)
Steinmetz (1967)

Jackson $(1975,1976)$

Lane (1983)

Shepherd (1987)

Olsen (1990)

Glennie (1970)

Hunter (1977)

Havholm \& Kocurek (1988)

Hunter (1973)

Ahlbrandt \&

Fryberger (1981)

Kocurek (1981)

Kocurek \& Nielson (1986)

Elliott (1974)

Hardie et al. (1978)

Smoot (1981)

Demicco \& Kordesh (1986)

Farrell (1987)

Williams (1971)

Picard \& High (1973)

Steel \& Aasheim (1978)

Olsen (1989)

Coleman (1969)

Collinson (1970)

Miall (1977)

Cant \& Walker (1978)

Bristow (1987)

Allen (1983)

Singh et al. (1993) 
Table 1. Cont.

Facies association

Characteristics

Interpretation

Main references

Gravelly stream association

Lacustrine association
(1) Tabular sheets, usually $0.5-1.5 \mathrm{~m}$ thick. Scour-and-fill bedding (dominant), horizontal lamination, massive bedding. (2) Channel-shaped bodies, usually a few metres thick. Scour-and-fill bedding, trough cross-bedding, parallel lamination, massive bedding.

(3) Disorganized boulder conglomerates and breccias.

(1) Black shales: bituminous, horizontally laminated; black limestones: bituminous, massive and horizontally laminated; mudstones: massive and horizontally laminated. Beds are $1-5 \mathrm{~m}$ thick.

(2) Siltstones (dominant) and sandstones: cross-laminated (wave ripples) and parallel laminated, desiccation cracks common. Beds usually $0.5-30 \mathrm{~cm}$ thick, usually occurring in stacked successions. (3) Crudely laminar limestone: carbonate and carbonate-cemented mudstone, laminated on a millimetre scale. Carbonate nodules and tepee structures. Interbeds of wave cross-laminated siltstone and sandstone.
(1) Alluvial fans and shallow braided channels. Sheetfloods (scour-and-fill bedding, horizontal lamination); longitudinal bars (massive and diffuse horizontal lamination).

(2) Gravelly braided perennial rivers Deposition mainly by dunes.

(3) Talus and piedmont.

(1) Deeper part of perennial lakes.

(2) Ephemeral lakes and margins of perennial lakes.

(3) Palustrine environments marginal to

lakes.
Rust $(1972,1978,1979)$

Smith (1974)

Blair (1987b)
Donovan (1980)

Demicco \& Kordesh (1986) Halfman \& Johnson (1988) Wright et al. (1987)$$
\text { . }
$$

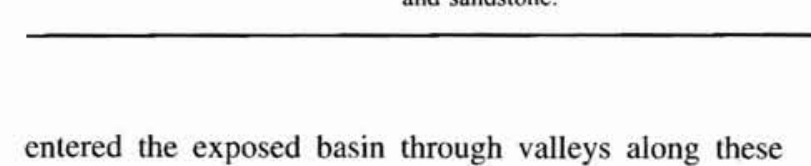
faults, clearly reflected in the SE direction of the palaeocurrents (Fig. 5). A gradual change from typical coarse proximal type rivers, dominated by longitudinal bars to intermediate type rivers dominated by finer-grained gravelly dunes is observed in the Ella $\varnothing$ succession. In the later phases of deposition of the Solstrand Formation the proximal (western) part of the alluvial system changed to well defined gravelly braided rivers with associated overbank areas with sheetfloods. In the distal part of the system sandy braided rivers and associated silty flood basins probably existed throughout the deposition of the formation (cf. Alexander-Marrack \& Friend, 1976). The interior of the basin was probably rather irregular with mountains rising high above the alluvial plain. This is suggested by the very irregular thickness variation of the Solstrand Formation (Alexander-Marrack \& Friend, 1976; Olsen \& Larsen, 1993a).

The Kap Bull Formation is restricted to the western part of the Moskusoksefjord in association with the socalled 'Moskusoksefjord inlier' (Bütler, 1959, Fig. 1B). The depositional system is dominated by tabular conglomerate sheets of the gravelly stream association (alluvial-fan sheetflood deposits) forming stacked 10-100 m

thick coarsening upward and coarsening-to-fining upward successions (Fig. 4, section 3). An internal unconformity exists in the uppermost part of the section overlain by gravelly braided river deposits. Palaeocurrents are towards NE. The depositional system represents an alluvial fan/braided river environment, locally developed in the interior of the basin, probably in connection to a small fault block.

Depositional complex 1, accordingly, was dominated by a gravelly braid plain draining eastwards (Solstrand Formation; Fig. 6). Small alluvial fans may have developed in connection with local tectonism and in the western Moskusoksefjord area a major alluvial fan existed for a prolonged period (Kap Bull Formation). Towards the end of complex 1 time, the rivers were smaller and associated with more extensive interchannel areas.

\section{Depositional complex 2}

Depositional complex 2 is composed entirely of the Ankerbjergselv Formation which is mainly built up of tabular, red and green sedimentary units, alternating on a 10 -metre scale. These are interpreted to reflect shortlived changes between ephemeral stream and braid plain 


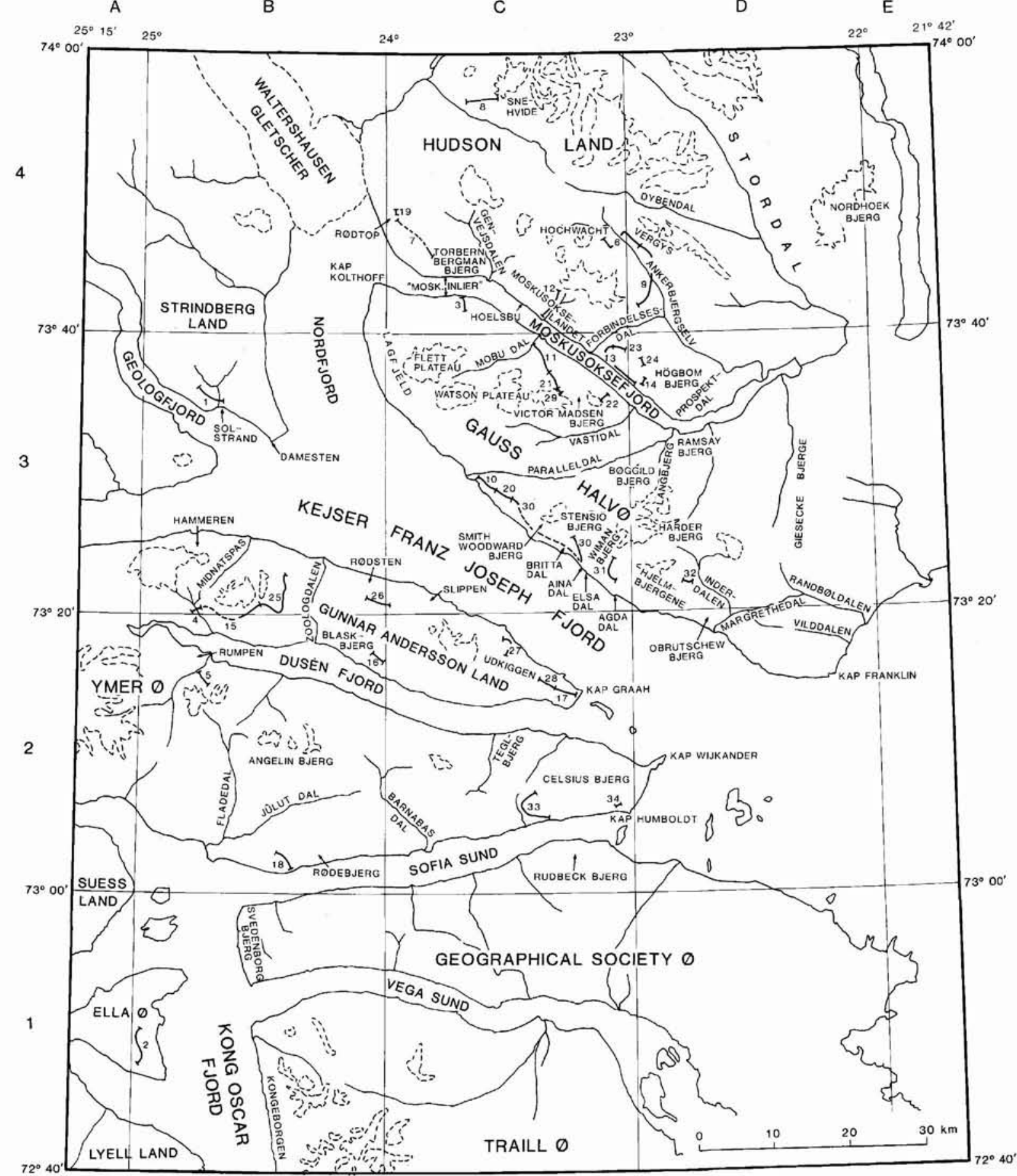

Fig. 3. Map of the study area with locality names used in text and figure captions. Positions of facies association logs are also indicated by bars and section numbers. Coastlines and major valleys are indicated by solid lines, outlines of glaciers are indicated by dashed lines. Place names with indication of position within the grid on facing page.

depositional systems. Red units are generally absent from the lowermost $300-400 \mathrm{~m}$, which are composed of green pebbly sandstones of the sandy braided river association in the main part of the basin, and grey/green lacustrine mudstones and siltstones in the east. Green units, in general, are dominated by the sandy braided river associ- 
Name

Agda Dal

Aina Dal

Angelin Bjerg

Ankerbjergsel

Barnabas Dal

Blaskbjerg

Britta Dal

Bøggild Bjerg

Celsius Bjerg

Damesten

Dusén Fjord

Dybendal

Ella Ø

Elsa Dal

Fladedal

Flett Plateau

Forbindelsesdal

Gauss Halvø

Genvejsdalen

Gcographical Society $\emptyset$

Geologfjord

Giesecke Bjerge

Gunnar Andersson Land

Hammeren

Harder Bjerg

Hjelmbjergene

Hochwacht

Hoelsbu

Hudson Land

Högbom Bjerg

Inderdalen

Jûlut Dal

Kap Franklin

Kap Graah

Kap Humboldt

Kap Kolthoff

Kap Wijkander

Kejser Franz Joseph Fjord

Kong Oscar Fjord

Kongeborgen

Lagfjeld

Langbjerg

Lyell Land

Margrethedal

Mobu Dal

Moskusoksefjord

'Moskusoksefjord inlier'

Moskusokselandet

Nordfjord

Nordhoek Bjerg

Obrutschew Bjerg

Paralleldal

Prospektdal

Ramsay Bjerg

Randbøldalen

Rudbeck Bjerg

Rumpen

Rødebjerg

Rødsten

Rødtop

Slippen

Smith Woodward Bjerg

Snehvide

Sofia Sund

Solstrand

Stensiö Bjerg

Stordal

Strindberg Land

Suess Land

Svedenborg Bjerg

Teglbjerg

Torbern Bergman Bjerg

Traill $\varnothing$

Udkiggen

Vastidal

Vega Sund

Vergys

Victor Madsen Bjerg

Vilddalen

Waltershausen Gletscher

Watson Plateau

Wiman Bjerg

Ymer $\emptyset$

Zoologdalen
Position

C3

B2 3

C4, D3, D4

$\mathrm{B} 2, \mathrm{C} 2$

B2

C3

C3, D3

C2

A2, B2, C2

C4, D4

Al, B1

C3

B2 $\mathrm{C} 4$

C3, C4, D4

B3, B4, C3, C4, D2, D3

C4

B1, B2, C1, C2, D1, D2, E1

$\mathrm{A} 3, \mathrm{~A} 4, \mathrm{~B} 3$

D2, D3

$\mathrm{A} 2, \mathrm{~A} 3, \mathrm{~B} 2, \mathrm{~B} 3, \mathrm{C} 2, \mathrm{C} 3$

B3

D3

C3, D2, D3

C4

B4, B5, C4, C5, D4

C3, D3

D2, D3

B2

$\mathrm{D} 2$

C2 2

A3, B3, C2, C3, D2, D3

B1

B3, B4, C3, C4

D3

Al, B I

D2, D3

$\mathrm{C} 3$

B4, C3, C4, D3

$\mathrm{C} 4$

C3, C4, D3, D4

B3, B4

D4, E4

D2, D3

C3, D3

D3

D2, D3

C2

B2

$\mathrm{B} 3, \mathrm{C} 3$

$\mathrm{B} 4, \mathrm{C} 4$

$\mathrm{C} 2, \mathrm{C} 3$

$\mathrm{C} 3$

B1, B2, C2

B3

C3

A3, A4, A5, B3, B4

A1, A2

B1

C4 4 , D3

B1, C1, D1

$\mathrm{C} 2$

C3, D3

B1, C1, D1

D4

C3

D2

B4

C3

$\mathrm{C} 32, \mathrm{~A} 3, \mathrm{~B} 2, \mathrm{~B} 3, \mathrm{C} 2, \mathrm{C} 3, \mathrm{D} 2$

$\mathrm{B} 2, \mathrm{~B} 3$ ation in the western part of the basin (Fig. 4, sections 1 \& 4). Down-current, in Hudson Land, the green units are dominated by laterally accreted sandstone bodies of the meandering river association (Fig. 4, section 6), and in the most distal outcrops, in the Kap Franklin area (Fig. 3), lacustrine siltstones and sandstones dominate (Alexander-Marrack \& Friend, 1976). The red units are dominated by sandstone sheets of the ephemeral stream association, which in the western (up-current) part can be locally interbedded with channel-shaped gravelly stream deposits (Fig. 4). Flood basin deposits, mainly composed of siltstones, are interbedded with the ephemeral stream deposits in the down-current successions and seem to dominate in the Kap Franklin area (Alexander-Marrack \& Friend, 1976). Palaeocurrents of the Ankerbjergselv Formation trend mainly SE in the western part of the basin and mainly $\mathrm{E}$ in the eastern part (Fig. 5).

The lower, green coloured part of the complex reflects deposition by sandy braided rivers over the main part of the basin from Strindberg Land to eastern Hudson Land. In the southeastern part of the region, the existence of one or several lakes (lowermost green and grey/green part of the formation) is recorded. The green coloured depositional systems in the upper, variegated part of the complex were characterized by braided rivers in the western region draining down-current into meandering rivers in Hudson Land. Further towards east and southeast, these rivers flowed into a lacustrine area. When red coloured systems existed, the proximal areas in the west were characterized by gravelly braided rivers and ephemeral streams with sand deposition. Further east, in Hudson Land, ephemeral streams dominated, associated with silty flood basins. In the most distal part of the study area, in eastern Moskusoksefjord and the Kap Franklin area, terminal flood basins dominated, associated with subordinate ephemeral streams. During deposition of the main, upper part of complex 2 the palaeogeography, accordingly, regularly changed from perennial fluvial systems and lakes (Fig. 7A) to rather ephemeral fluvial systems and flood basins (Fig. 7B). The SE palaeocurrents in the western part of the basin may indicate a fault control, as discussed for the Solstrand Formation.

\section{Underlying controls}

West of the present day Devonian basin two major NNE-SSW normal faults transect the crystalline basement and the Caledonian fold structures in the sedimentary cover. These faults have very large downthrows to the east in the order of $5-10 \mathrm{~km}$, and bound a $90 \mathrm{~km}$ wide block, which was tilted $12^{\circ}$ (Larsen \& Bengaard, 1991). The block tilting is dated to Middle Devonian (Larsen \& Bengaard, 1991), coinciding with the dating of 

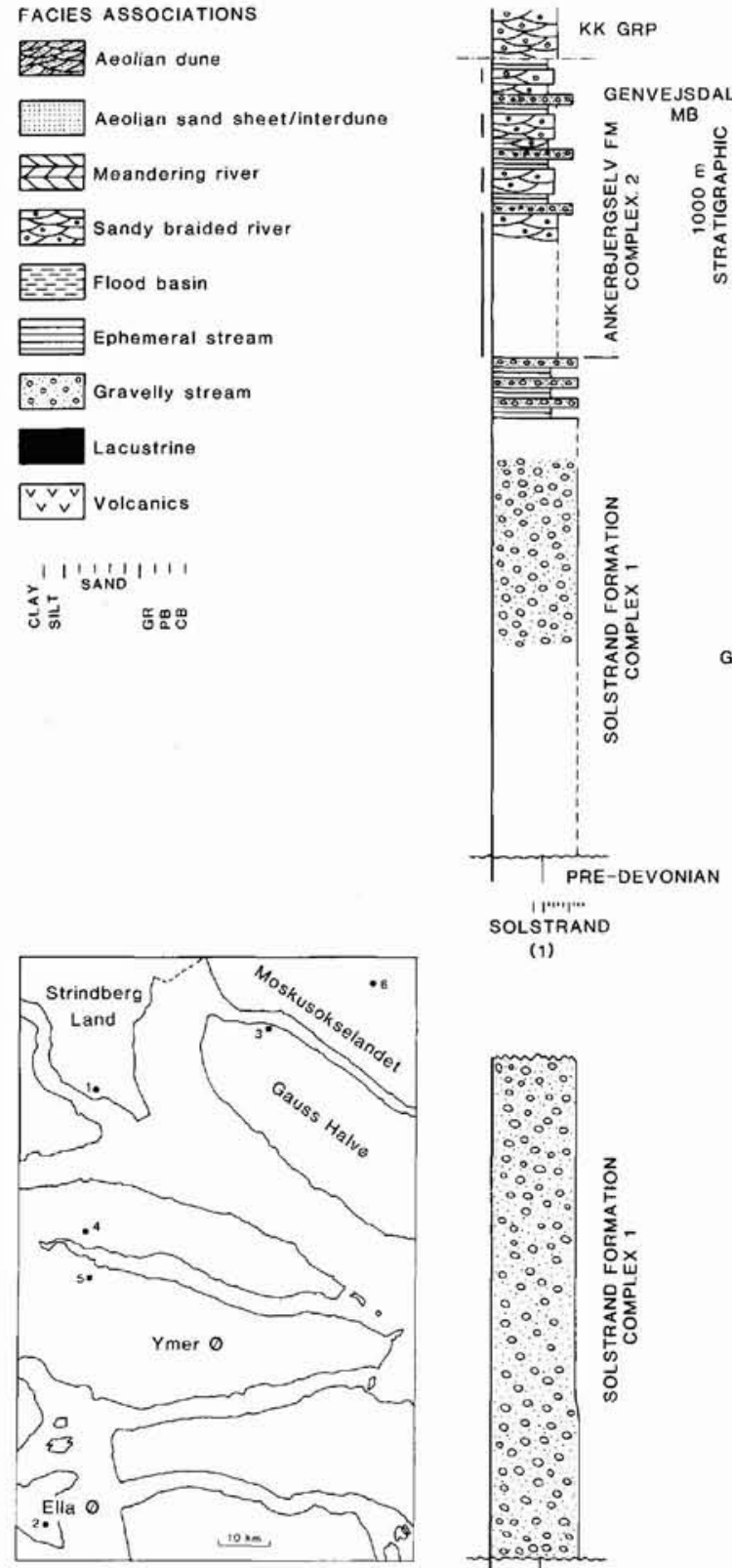

(1)

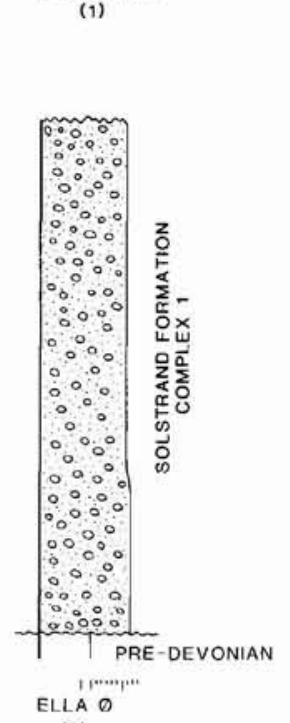

(2)

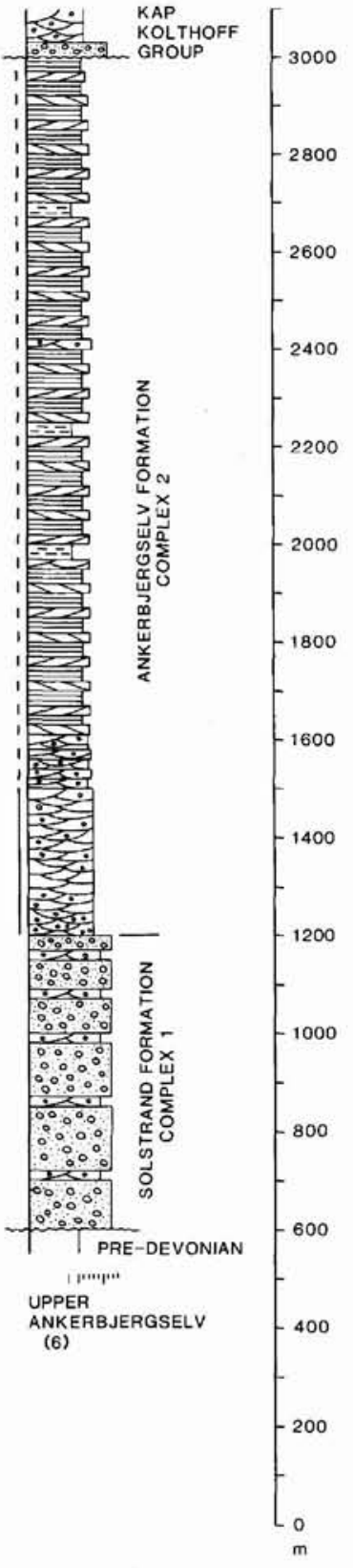

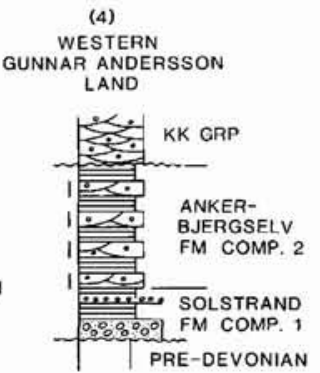

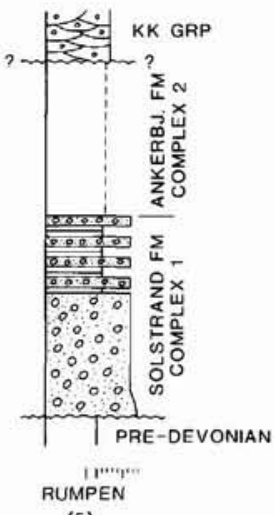

(5)
(1,......"

ESTERN

SOKSEFJORD

(3)

近

这势

GNEISS

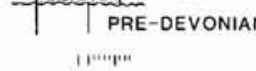

Fig. 4. Facies association logs from the Vilddal basin stage represented by sediments of the Vilddal Group. Intervals with no field observations by me or any colleagues are indicated by dashed lines and lack of signature. Section 5 is measured by P.-H. Larsen. The Solstrand and Kap Bull Formations collectively form depositional complex 1, whereas the Ankerbjergselv Formation forms complex 2. Lines along the lefthand side of logs indicate green coloured units in the Ankerbjergselv Formation.

the Vilddal Group (Olsen \& Larsen, 1993a) and interpreted as caused by an extensional collapse of an overthickened crustal welt following the Caledonian orogeny (Larsen \& Bengaard, 1991).

In addition to the extensional faults a sinistral obliqueslip fault zone (the Western Fault Zone) developed along the western boundary of the Devonian basin exposed today (Larsen \& Bengaard, 1991). A general downthrow to the east in the order of $3 \mathrm{~km}$ is estimated. The strikeslip component, estimated to be in the order of $10 \mathrm{~km}$, led to the formation of antithetic and synthetic Riedel shears. The former are E-W orientated high-angle faults while 


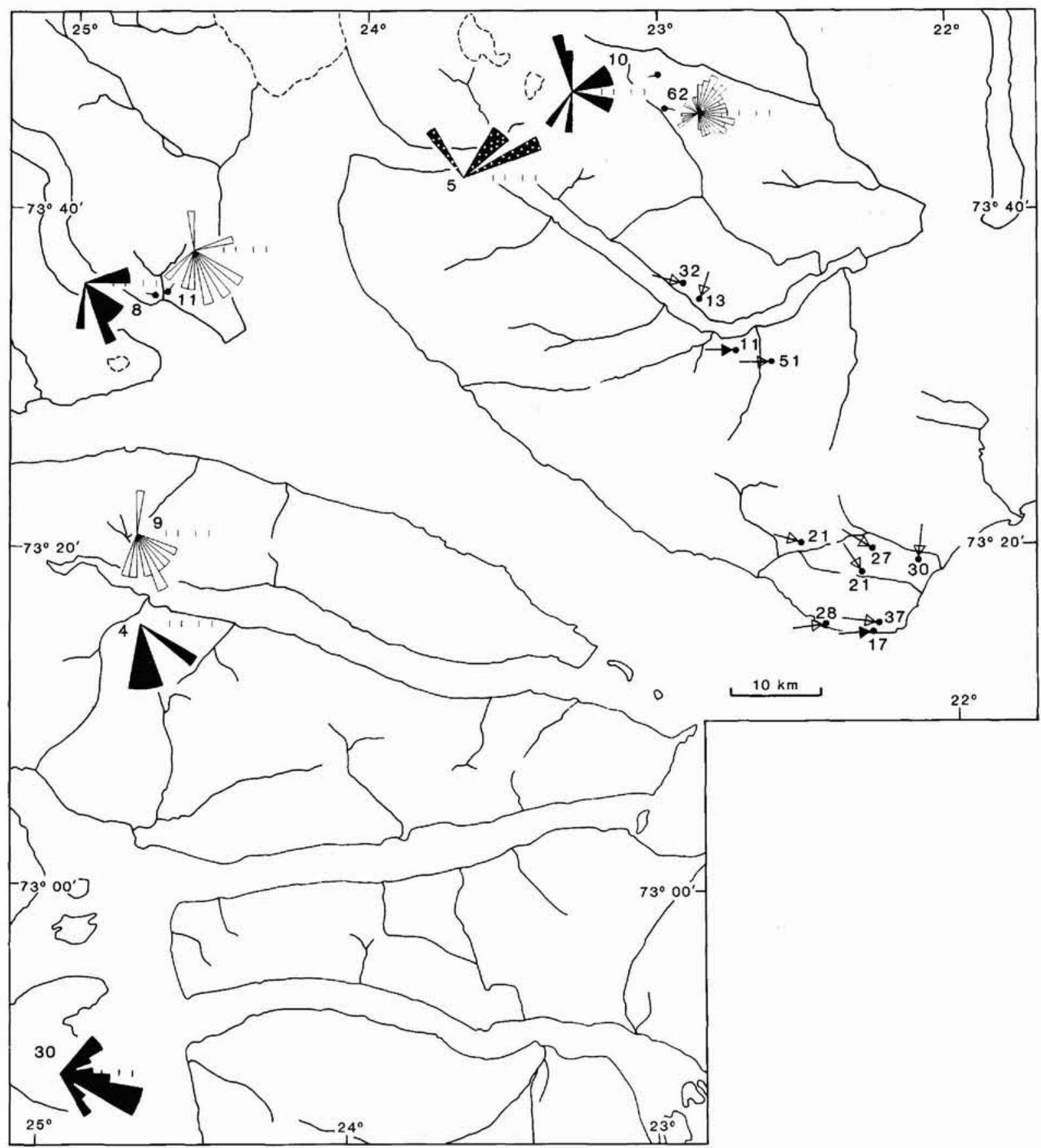

Fig. 5. Palaeocurrent roses from the Vilddal basin stage. Solid and open roses indicate measurements from the Solstrand Formation and Ankerbjergselv Formation, respectively. Solid rose with spotted signature is from the Kap Bull Formation. Solid and open arrows are measurements from the Solstrand and Ankerbjergselv Formations, respectively, taken from Alexander-Marrack \& Friend (1976). Numbers by roses and arrows are indications of the number of measurements. The roses are areal plots. Five, 10, 20 and 30 percent measurements are indicated. Centre of rose indicates the locality where measurements were obtained, unless otherwise stated by a dot. Measurements from Ella $\emptyset$ were collected by P.-H. Larsen.

the latter are NW-SE orientated high-angle faults with large downthrows to the NE close to the basin (Larsen \& Bengaard, 1991). The small-scale half-grabens produced in connection to the synthetic faults acted as valleys and are filled with conglomerates of the Solstrand Formation e.g. at Ella $\emptyset$ and at Solstrand. The palaeocurrents in- 
dicate that the rivers flowed along these faults which probably were exposed as huge subvertical fault scarps. Accordingly, the extensional collapse, the wrench tectonics and the initiation of Devonian deposition seem to be contemporaneous. Movements along the Western Fault Zone are believed to have continued during the entire basin stage, although no detailed investigations have been carried out to confirm this.

The presence of the major alluvial fan system (Kap Bull Formation) in Moskusoksefjord and the existence of an internal unconformity in this system indicates that tectonism continued in the interior of the basin after basin initiation. The stacking of coarsening and coarsening-tofining upward successions of alluvial-fan sheetflood deposits with no incised channel deposits seems to imply high tectonic activity (cf. Blair, 1987a).

The change from coarse to finer-grained fluvial deposition in late complex 1 time is probably related to a lowering of the relief in the hinterlands due to reduced tectonic activity. This would eventually result in a change from dominantly physical weathering to dominantly chemical weathering and thus production and deposition of finer-grained material (cf. Press \& Siever, 1974). Alternatively, the facies change may indicate a reduction in precipitation in the hinterlands and thus reduced discharge and carrying capacity of streams. In the light of the general change in climatic regime reflected in the

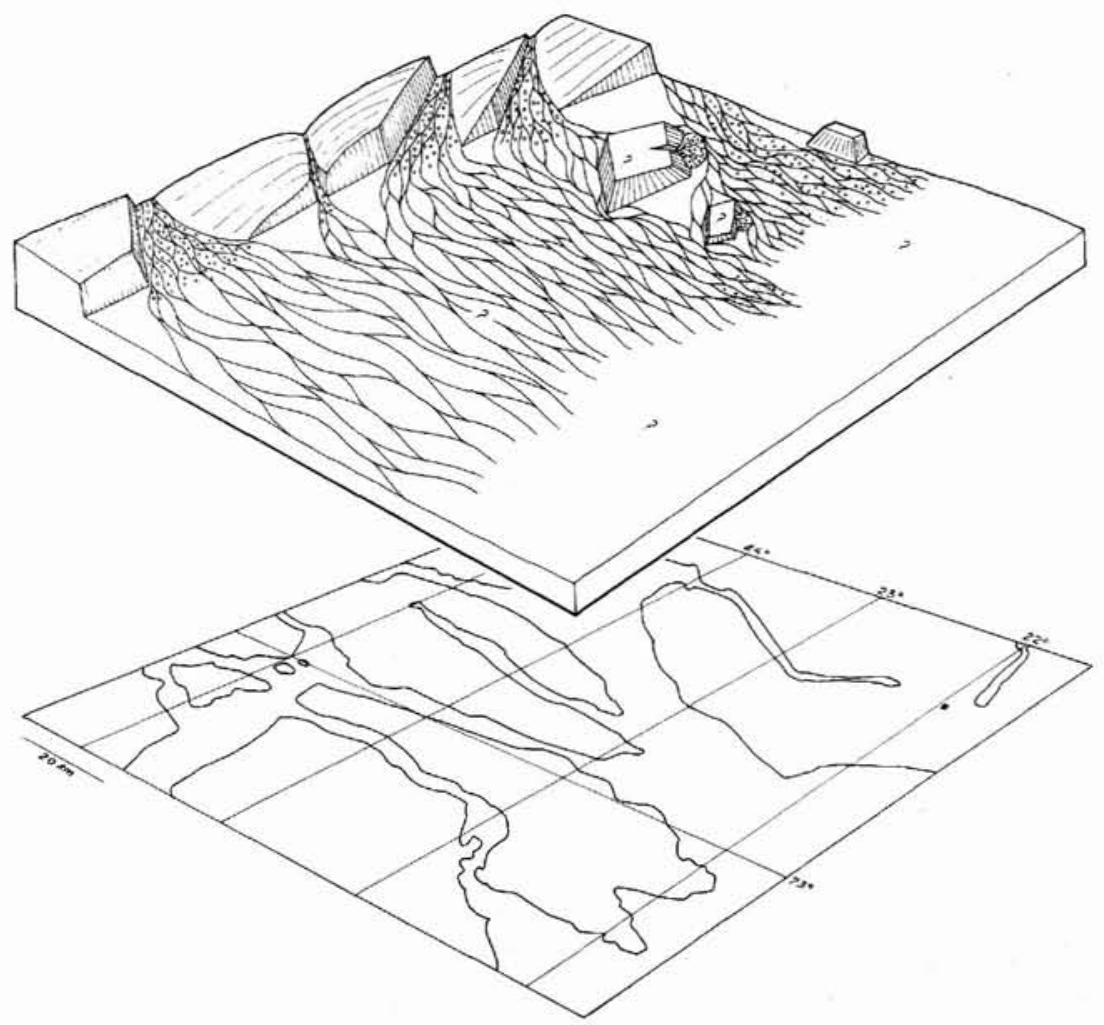

succeeding complex (see below) this latter interpretation is preferred.

The transition to depositional complex 2 is probably related to a change in climatic regime. Depositional processes of red coloured systems were dominated by ephemeral streams; green coloured depositional systems, in contrast, were characterized by perennial rivers draining into lacustrine areas, indicating more humid conditions. Accordingly, depositional complex 2 reflects regular changes in the palaeogeography due to regular changes in the climate. Alexander-Marrack \& Friend (1976) noted significant thickness variations of coloured units between different localities suggesting that local subsidence varied greatly in the basin.

Although the western limits of outcrops seem to have been the Devonian basin margin during the Vilddal stage, the present outcrop area probably only represents a subbasin of a Devonian basin of much larger extent (Larsen \& Bengaard, 1991) or the easternmost basin in a series of $\mathrm{N}-\mathrm{S}$ striking basins. The large fault-related valleys at e.g. Solstrand and Ella $\emptyset$ acted, accordingly, as connections between the western part of this basin system, not exposed at present, and the basin now exposed. Sedimentological indication of an eastern margin to the basin does not occur in the outcrop area (Alexander-Marrack \& Friend, 1976).
Fig. 6. Palaeogeographic reconstruction of depositional complex 1. The exposed parts of the complex are indicated by gravel and sand signatures; the reconstruction elsewhere is hypothetical. The palaeogeography is dominated by an eastward draining braid plain, represented by the Solstrand Formation. In the western Moskusoksefjord area the Kap Bull Formation alluvial fan existed. 
Fig. 7. Palaeogeographic reconstruction of depositional complex 2 during deposition of green units $(\mathrm{A})$ and red units (B) of the Ankerbjergselv Formation. Green units are characterized by perennial fluvial and lacustrine systems, whereas the red units dominantly represent ephemeral fluvial and lacustrine systems. Drainage is eastwards. Apart from the speculative streams without lithology signature only exposed parts of the formation are reconstructed.

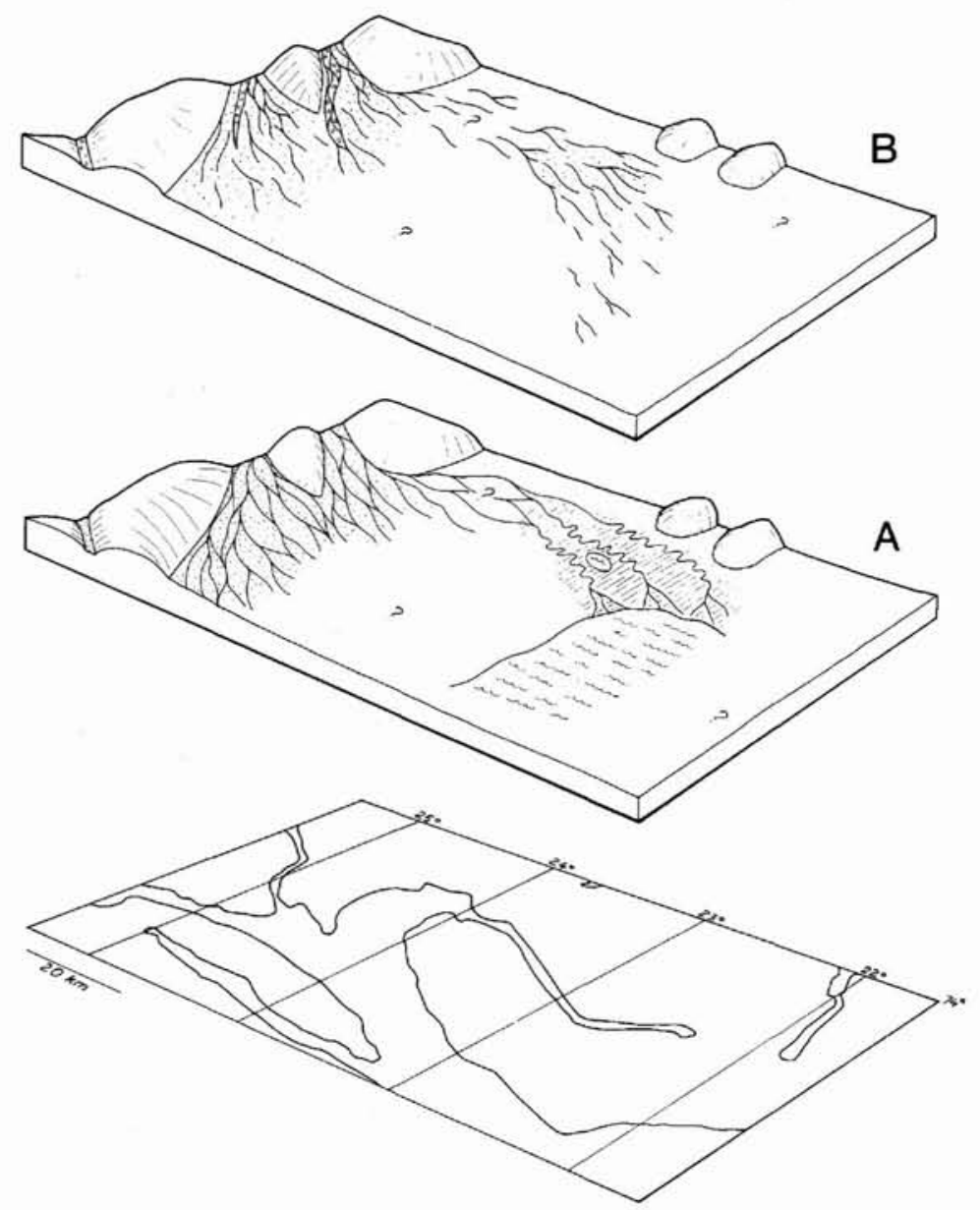

\section{Kap Kolthoff - Kap Graah basin stage: southward draining alluvial plains and associated aeolian systems}

The Kap Kolthoff - Kap Graah basin stage (GivetianFamennian) comprises the deposits of the up to $2700 \mathrm{~m}$ thick Kap Kolthoff Group and the up to 1300 m thick Kap Graah Group (Fig. 2). The Kap Kolthoff - Kap Graah basin stage is distinguished from the Vilddal basin stage by the shift to a southward directed tributary drainage pattern along a $\mathrm{N}-\mathrm{S}$ axis. The dominant deposition is by alluvial systems but major aeolian systems also occur. The deposits of this stage overlie sediments of the Vilddal basin stage, separated by a basin-scale unconformity (Olsen \& Larsen, 1993a). In Strindberg Land, Ymer $\varnothing$ and at the 'Moskusoksefjord inlier' the base is defined by onlap surfaces (Fig. 8). In eastern Hudson Land and central Gauss Halv $\emptyset$ the base is defined by parallel unconformities, and the basin fill rests on different stratigraphic levels of the Vilddal basin fill.

The Kap Kolthoff - Kap Graah basin stage is subdivided into three complexes of which the lowermost is represented by the Kap Kolthoff Group (complex 3) and the two upper by the Kap Graah Group (complexes 4 and 5; Fig. 2). Complex 3 is mainly fluvial though locally aeolian systems dominate. Complex 4 is dominantly aeolian and is succeeded by the alluvial and aeolian complex 5. A reversal of palaeoslope from dominantly southwards in the Kap Kolthoff - Kap Graah basin stage to generally northwards marks the transition to the Celsius Bjerg basin stage.

\section{Depositional complex 3}

Eight depositional systems have been defined in complex 3, represented by the Sofia Sund, Vergys, Barnabas Dal, Langbjerg, Madsen Bjerg, Snehvide, Rødebjerg and Midnatspas Formations (Fig. 2 and Figs 9-12).

The Sofia Sund Formation probably forms more than $90 \%$ of complex 3, and all other depositional systems of this complex form large-scale sedimentary prisms in the Sofia Sund Formation. The sandy braided river associ- 


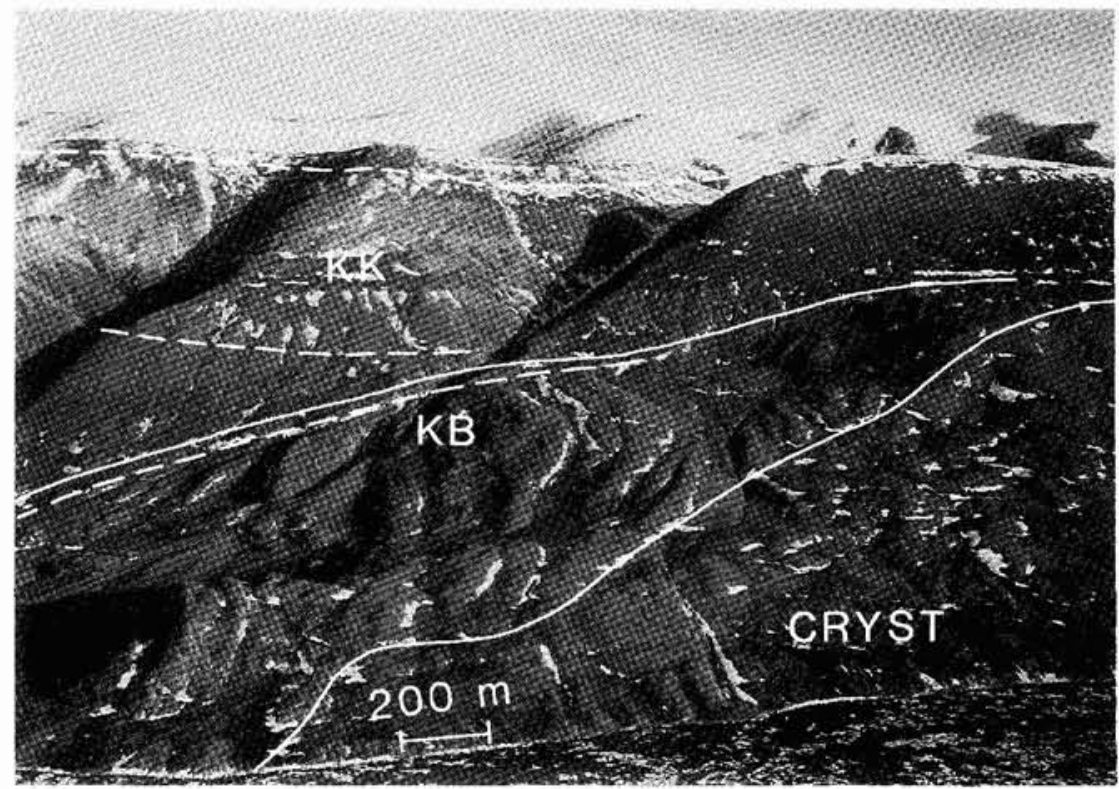

Fig. 8. Onlap unconformity defining the lower boundary of the Kap Kolthoff - Kap Graah basin stage. The Kap Kolthoff Group (KK) onlaps the Kap Bull Formation (KB). Southeastern part of the crystalline 'Moskusoksefjord inlier' (CRYST), looking towards the south. (Photograph by J. Lautrup.)

ation, with trough cross-bedded pebbly sandstones, dominates the depositional system of the Sofia Sund Formation (Figs 9-12). Channel-shaped conglomerates (gravelly stream association) are locally important near the basin margins, although always subordinate to sandy braided river deposits. Locally, and mainly in the lower part of the formation thin units of ephemeral stream and aeolian deposits may occur. The depositional system is basin-wide, and exhibits a symmetrical tributary palaeocurrent pattern with a general southward component (Fig. 13). It records the existence of a symmetrical basin-scale sandy braid plain, draining southwards.

The depositional system of the Vergys Formation is restricted to a local area in Hudson Land, and is mainly composed of pebbly sandstones of the sandy braided river association. In the proximal part channel-shaped conglomerates of the gravelly stream association also occur (Fig. 9, section 9) whereas a considerable proportion of the distal part of the system is composed of lacustrine laminated siltstones and sandstones with thin black shale units, also of lacustrine origin. Palaeocurrents are towards the SE (Fig. 14), exhibiting a local deviation in drainage compared to the Sofia Sund system.

The depositional systems of the Barnabas Dal, Langbjerg and Madsen Bjerg Formations are almost identical, composed mainly of cross-bedded sandstones of the aeolian dune association (Fig. 10, sections 11-14; Fig. 12, section 18). These depositional systems record the existence of local ergs with compound dunes migrating in directions ranging between $\mathrm{W}$ (most common) and NE (Figs 14, 15).

The depositional systems represented by the Snehvide and Rødebjerg Formations also share many characteristics. The proximal part (not exposed in the Rødebjerg system) consists of channel-shaped conglomerates of the gravelly stream association with thin sandstone and siltstone interbeds of the flood basin association and pebbly sandstones of sandy braided river origin (Fig. 9, section 8). Down-current pebbly sandstones of the braided river association prevail. Further down-current both systems exhibit interbedding of deposits of the sandy braided river association and sheetflood deposits of the ephemeral stream association, giving way further down-current to interbedding of low sinuosity ephemeral stream, sheetflood, aeolian sandsheet, aeolian dune, flood basin and (minor) sandy braided river deposits. These deposits wedge out in aeolian dune and sandsheet sandstones. The two depositional systems are interpreted as terminal fans (Kelly \& Olsen, 1993). The headwaters of the systems were located at the northern basin margin (Snehvide Formation) and the western basin margin (Rødebjerg Formation) and drainage was generally southwards (Figs $16,17)$. Palaeowind directions are mainly northwards (Fig. 17). The Snehvide system is closely associated with rhyolites in Moskusokselandet, which seem to imply the coexistence of volcanoes in this area. Local deviations in the palaeocurrent directions in western Moskusokselandet (Fig. 16) may be due to topographic features formed by the volcanoes and the "Moskusoksefjord inlier'.

The Midnatspas Formation is a depositional system composed of laterally accreted sandstone bodies (meandering river association) and flood basin mudstones (Fig. 11 , section 15). It is interpreted as a local meander belt 
Fig. 9. Depositional complex 3 (Kap Kolthoff Group) from the Kap Kolthoff - Kap Graah basin stage in Hudson Land. Intervals with no detailed observations are indicated by dashed lines and lack of signatures. For legend see Fig. 4 .

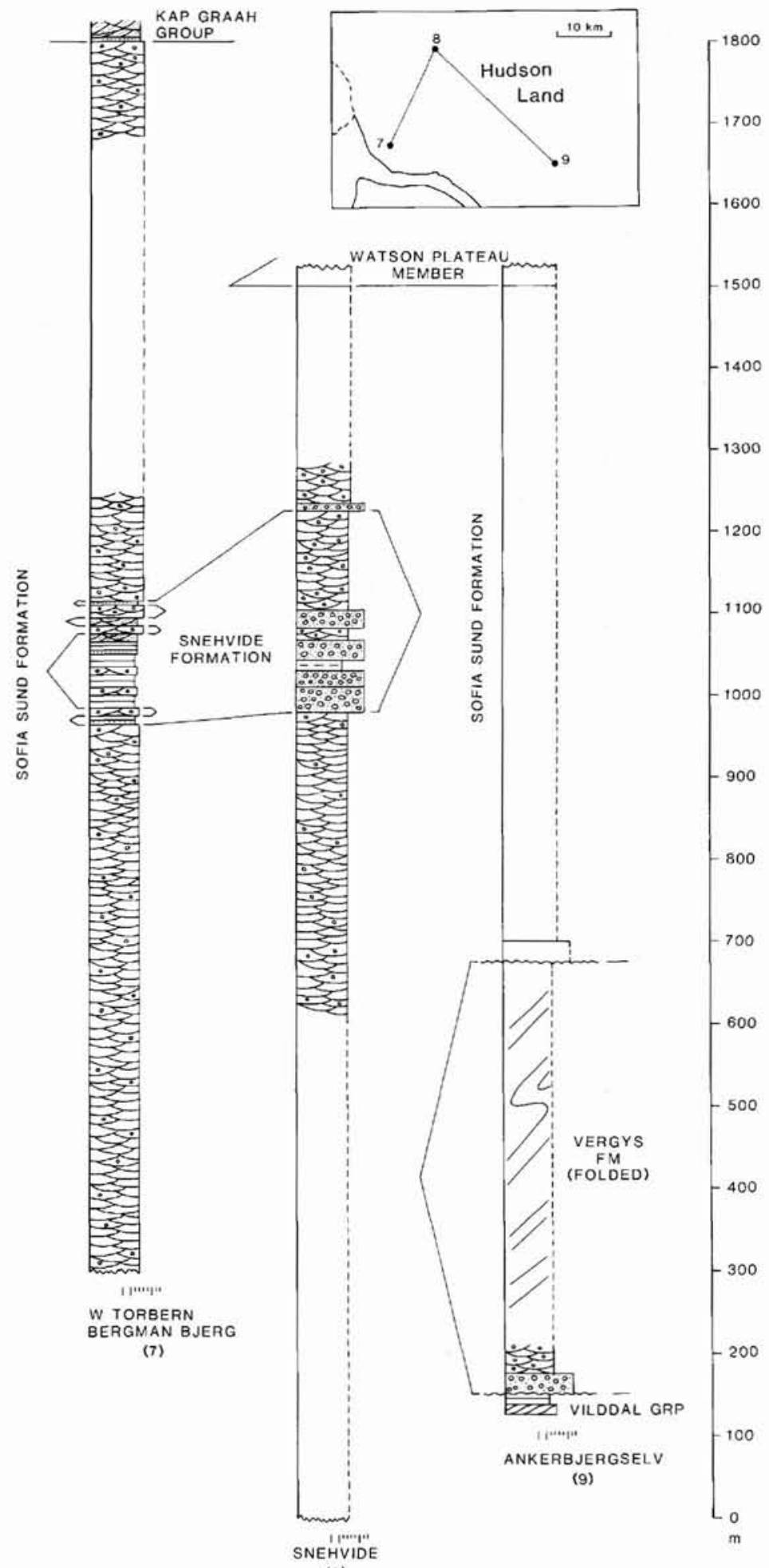

(8)

draining a part of the western basin margin. It was not studied in detail.
The dominance of the Sofia Sund system, which extends from the base to the top of the complex, with 


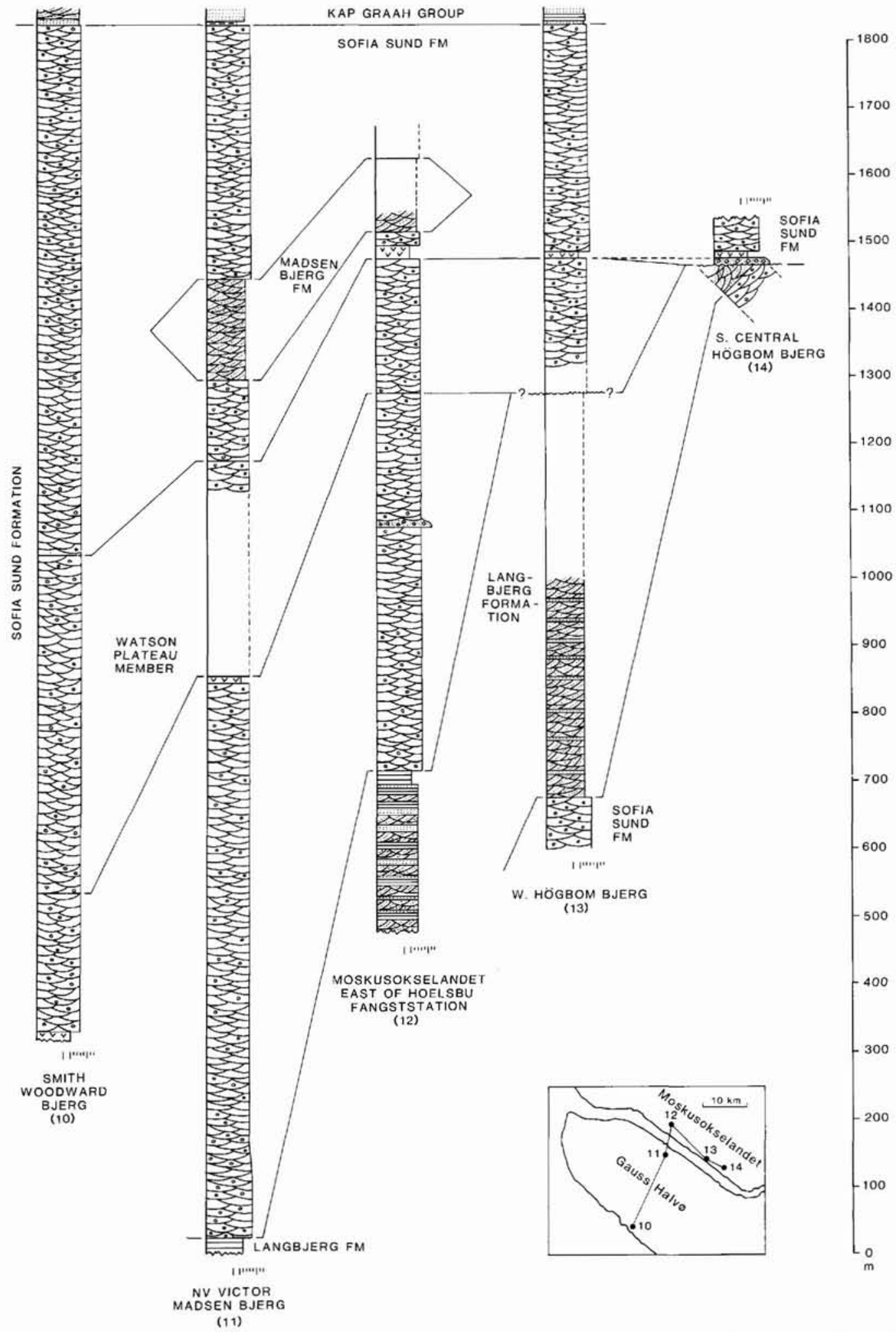

Fig. 10. Depositional complex 3 (Kap Kolthoff Group) from the Kap Kolthoff - Kap Graah basin stage in Gauss Halvø and Moskusokselandet. Intervals with no detailed observations are indicated by dashed lines and lack of signature. For legend see Fig. 4. 


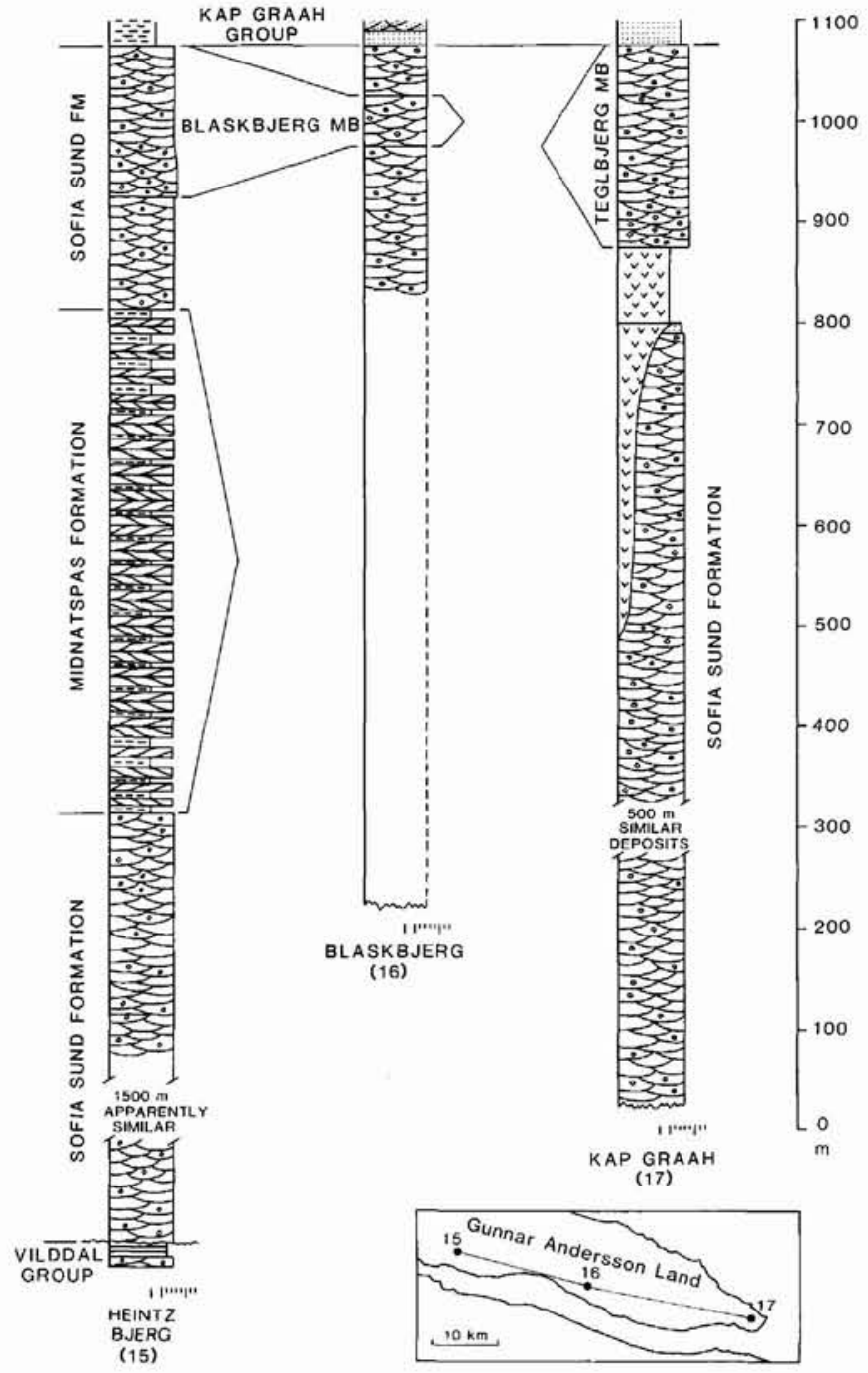

Fig. 11. Depositional complex 3 (Kap Kolthoff Group) from the Kap Kolthoff - Kap Graah basin stage in Gunnar Andersson Land. Intervals with no detailed observations are indicated by dashed lines and lack of signature. For legend see Fig. 4.

Fig. 12. Depositional complex 3 (Kap Kolthoff Group) from the Kap Kolthoff - Kap Graah basin stage at Rødebjerg on Ymer $\emptyset$. The uppermost part of the exposed section was not studied. Several hundred metres of mainly sandy braided river deposits occur below the section shown, but intense faulting prohibits a precise correlation. For legend see Fig. 5.

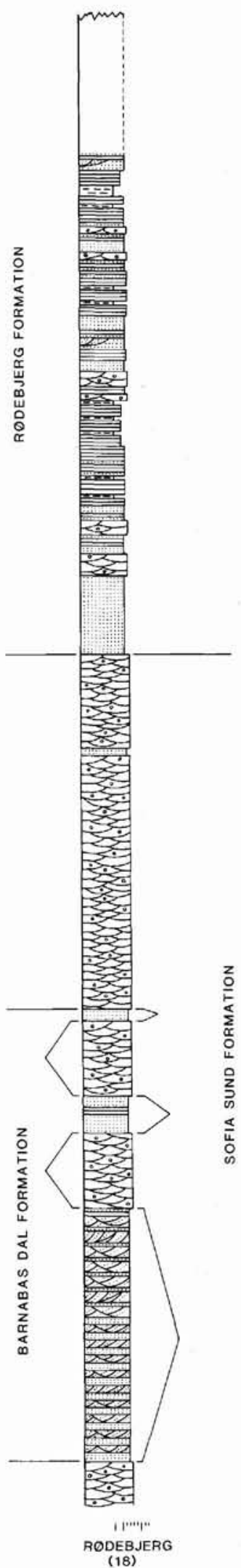

2000

1900

1800

1700

1600

1500

1400

1300

1200

1100

$-1000$

900

800

$-700$

600

500

400

300

200

100

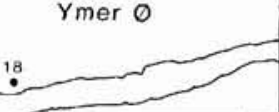

(18) 


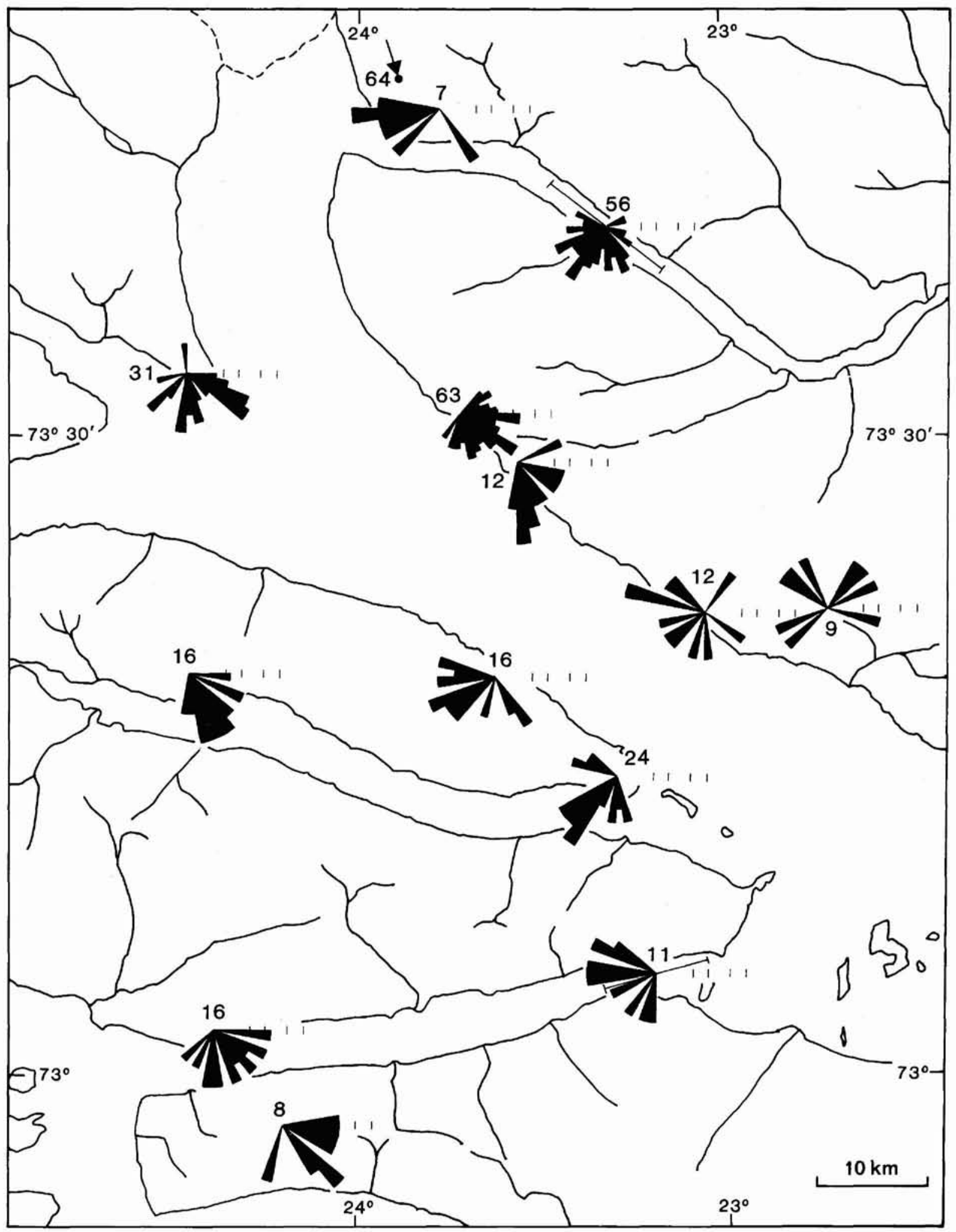

Fig. 13. Palaeocurrent roses from the Sofia Sund Formation of depositional complex 3 . The centre of the roses indicates the locality, except where a bar is associated with the rose. This indicates that measurements from several localities along the bar contributed to the rose diagram. The roses are areal plots; $5,10,20$ and 30 percent of measurements are indicated. The arrow at Rødtop is obtained from Nicholson \& Friend (1976, fig. 43). Number of measurements is indicated at each rose and arrow. 


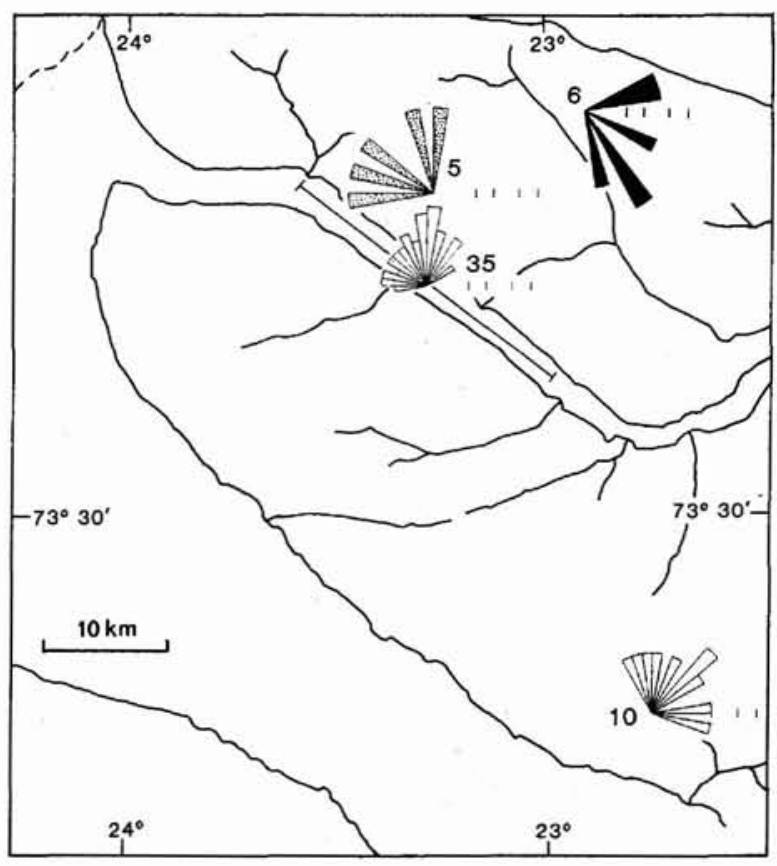

Fig. 14. Palaeocurrent and wind roses (areal plots) from the Vergys Formation (solid), Langbjerg Formation (open) and Madsen Bjerg Formation (spotted) of depositional complex 3. Centre of the roses indicates the localities, except where a bar is shown, indicating that measurements from several localities along the bar contributed to the rose diagram. Five, 10,20 and 30 percent of measurements are indicated. Number of measurements is indicated at each rose.

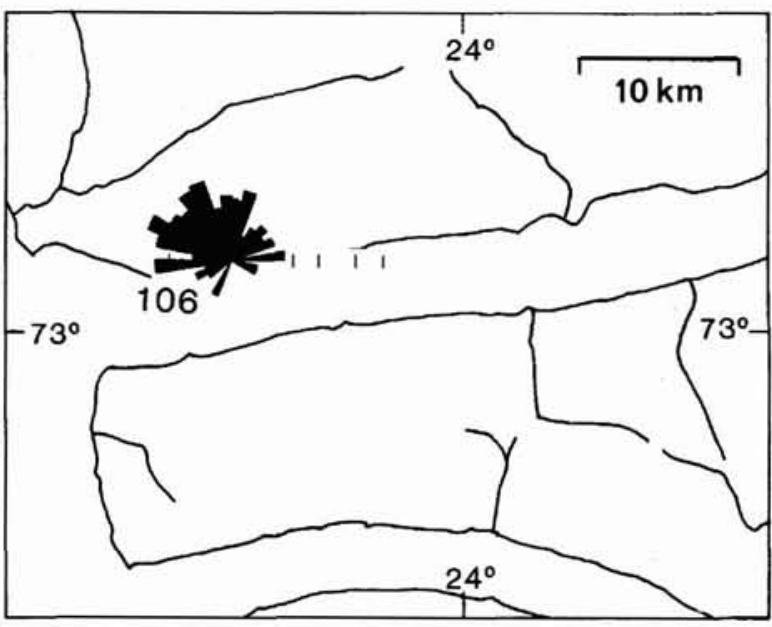

Fig. 15. Palaeowind rose (areal plot) from the Barnabas Dal Formation, depositional complex 3 . The centre of the rose indicates the locality and short lines indicate 5, 10, 20 and 30 percent of measurements for individual azimuthal intervals. Number of measurements is also provided.

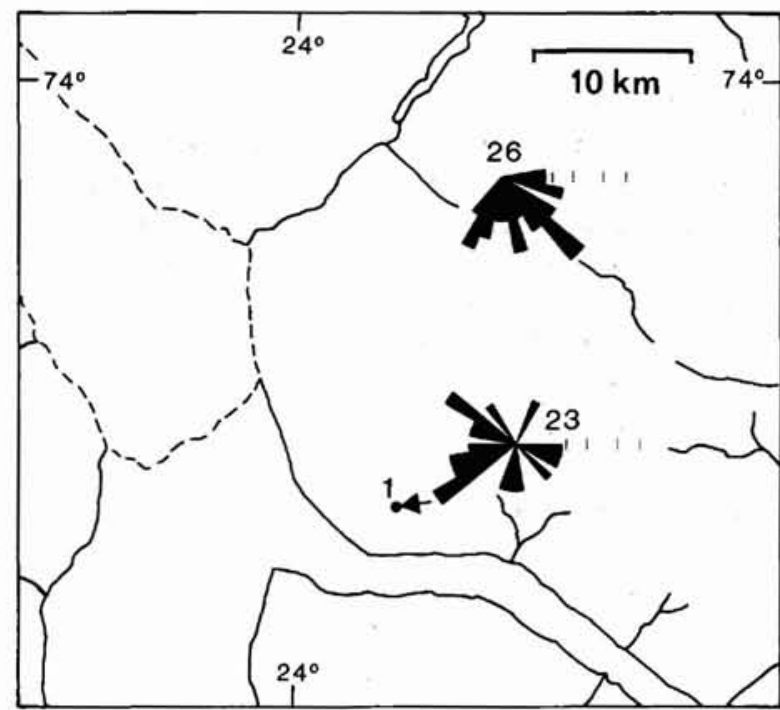

Fig. 16. Palaeocurrent roses (areal plots) from the Snehvide Formation, depositional complex 3. Centre of the roses indicates the localities. Five, 10, 20 and 30 percent of measurements as well as number of measurements are indicated. The arrow indicates that only one measurement was obtained at this locality.

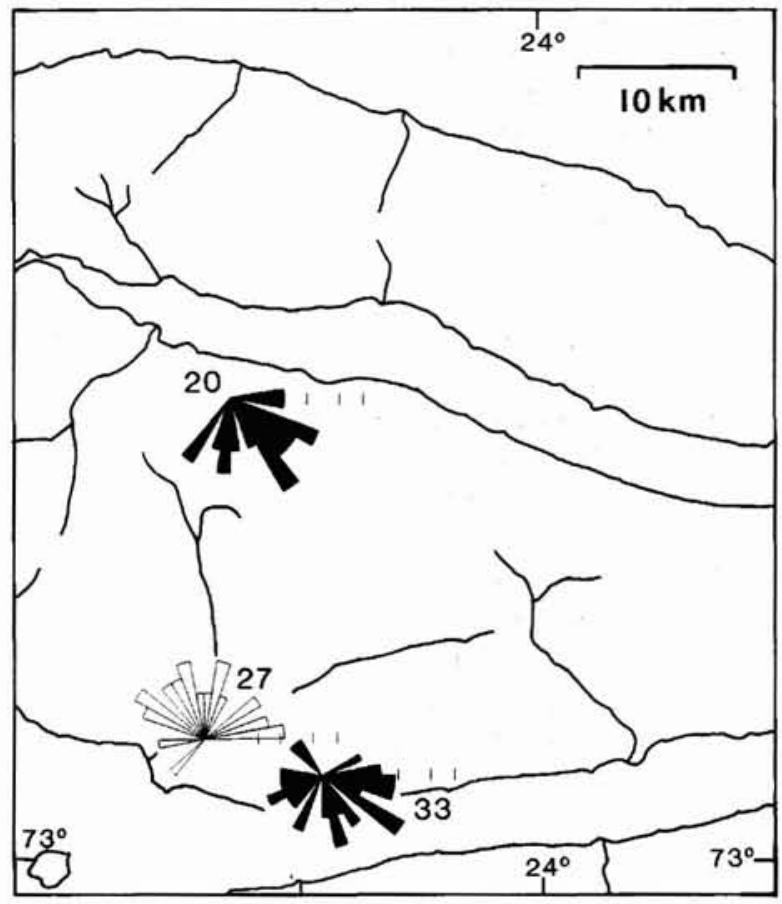

Fig. 17. Palaeocurrent and wind roses (areal plots) from the Rødebjerg Formation, depositional complex 3. Currents are indicated by solid roses. The centre of the roses indicates the localities for the measurements. Percentages of measurements are indicated by lines $(5,10,20,30 \%)$. Number of measurements is indicated. 
subordinate depositional systems occurring as sedimentary prisms within this system, implies that the Sofia Sund braid plain existed throughout the depositional history of complex 3 . It is possible to unravel the relative timing of initiation and disappearance of the subordinate depositional systems locally, but not within the basin as a whole. Accordingly, in the reconstructions (Fig. 18) the constituent depositional systems may not necessary have coexisted as shown.

The basic palaeogeography of depositional complex 3 is a huge basin-wide sandy braid plain represented by the Sofia Sund Formation (Fig. 18A). The basin was initially bounded by a worn-down inactive western margin, which through time was locally transgressed (Olsen \& Larsen, 1993b), so that the present outline of the basin may represent the deeper part of a much larger basin. The eastern part of the basin was repeatedly uplifted, as indicated by progressive angular unconformities along the eastern basin margin (Larsen, 1990d; see also Fig. 58). In the eastern Moskusoksefjord area the 'Moskusoksefjord inlier' and associated sedimentary cover formed a topographic feature, and volcanoes in this area may also have controlled the drainage pattern (Fig. 13). The braid plain was characterized by a symmetrical drainage pattern and an overall southward palaeoslope. This basic palaeogeography without coexisting depositional systems probably existed several times during deposition of the complex.

Early in the depositional history of the complex the Vergys Formation was formed. Braid plain conditions probably existed in the main part of the basin (Sofia Sund and part of Vergys Formations) while a lake of unknown lateral extent occurred in Moskusokselandet, represented by the distal part of the Vergys system (Fig. 18B).

The next time-slice indicates the existence of two ergs (Fig. 18C). One was situated in Moskusokselandet and Gauss Halvø, represented by the Langbjerg Formation. This erg was bounded to the west by the 'Moskusoksefjord inlier'. In the south, on Ymer $\emptyset$ and probably also on Geographical Society $\emptyset$ and Traill $\varnothing$, the erg of the Barnabas Dal Formation occurred.

Later, the area occupied by the Barnabas Dal erg was transgressed by the Sofia Sund braid plain system until the terminal fan system of the Rødebjerg Formation took over. This terminal fan may have coexisted with the terminal fan system of the Snehvide Formation in the north (Fig. 18D). The Snehvide terminal fan was bounded towards the east and southeast partly by the 'Moskusoksefjord inlier' and partly by volcanoes. The volcanoes may have developed in association with E-W trending faults which apparently offset the 'inlier' in a dextral sense prior to or during deposition of the Sne- hvide system (P.-H. Larsen, personal communication, 1990).

Finally, towards the termination of complex 3 a part of the alluvial plain was characterized by a meander belt system, the Midnatspas Formation. It may have coexisted with a small erg, represented by the Madsen Bjerg Formation (Fig. 18E). The topmost deposits of complex 3, conformably overlain by complex 4 , is everywhere represented by the Sofia Sund Formation, indicating the existence of a huge braid plain immediately prior to the development of the aeolian-dominated complex 4 (Fig. 18A).

\section{Depositional complex 4}

Depositional complex 4 comprises three depositional systems, represented by the Udkiggen, Zoologdalen and Rødsten Formations (Figs 19, 20). Whereas the Udkiggen Formation is restricted to complex 4 , the two other formations also occur in the succeeding complex 5 (Figs 19, 20).

Complex 4 is dominated by the Udkiggen Formation. This depositional system is almost entirely composed of aeolian sandstones, mainly the aeolian dune association but also of the aeolian sand sheet/interdune association. The aeolian dune sandstones exhibit very thick simple sets and adjacent cosets of trough cross-bedding, attaining a maximum of $20 \mathrm{~m}$. The system is interpreted in terms of a basin-wide erg with large compound dunes (Olsen \& Larsen, 1993b) migrating in southwestward directions (Fig. 21). Locally sand sheets occurred, with only small widely spaced dunes.

The Zoologdalen Formation occurs in the western outcrops of complex 4 (Fig. 20) and consists mainly of siltstones of the flood basin association with aggraded channel sandstones of low sinuosity ephemeral stream origin forming important constituents in the westernmost outcrops. Palaeocurrents are towards SE (Fig. 21) and the sediments are interpreted as part of a terminal fan system, with its headwaters in the western borderlands of the basin (Olsen \& Larsen, 1993b).

In complex 4 the Rødsten Formation is restricted to the easternmost exposures at Högbom Bjerg and Kap Graah (Figs 19, 20, sections $24 \& 28$ ). The depositional system is dominated by sandstones of the sandy braided river and ephemeral stream associations with thin intercalations of aeolian sandstones. Palaeocurrents are towards WSW. The sparse information makes a definite interpretation of the type of depositional system difficult, but in the light of the information from the main part of the formation in complex 5 (see below), the system is interpreted as termi- 
Fig. 18. Palaeogeographic reconstructions of depositional complex 3, the Kap Kolthoff Group, shown in stratigraphic order (E is youngest), although palaeogeography A probably existed several times. (A) Sandy braid plain draining southwards (Sofia Sund Formation). Now and then this monotonous palaeogeography was broken by the local development of other depositional environments (see B-E), but the Sofia Sund braid plain was dominant throughout complex 3 . In B-E the Sofia Sund system is shown without spotted signature. (B) Braid plain and lacustrine environments of the Vergys Formation. (C) Ergs with compound dunes (Barnabas Dal Formation (southwest) and Langbjerg Formation (northeast)). The Langbjerg erg is bounded laterally to the west by an anticline, the so-called 'Moskusoksefjord inlier' (M). (D) Terminal fans with aeolian dune fields developed in their basinal (downcurrent) portions (Snehvide Formation in the north, and Rødebjerg Formation in southwest). The Snehvide terminal fan was partly bounded by volcanoes and the 'Moskusoksefjord inlier' (M). The inlier was probably offset by an E-W trending fault. (E) A meander belt and a small erg (Midnatspas Formation in southwest, and Madsen Bjerg Formation in northeast). Volcanoes existed in the Moskusoksefjord area. The 'Moskusoksefjord inlier' was probably transgressed at this late stage of Kap Kolthoff Group deposition.

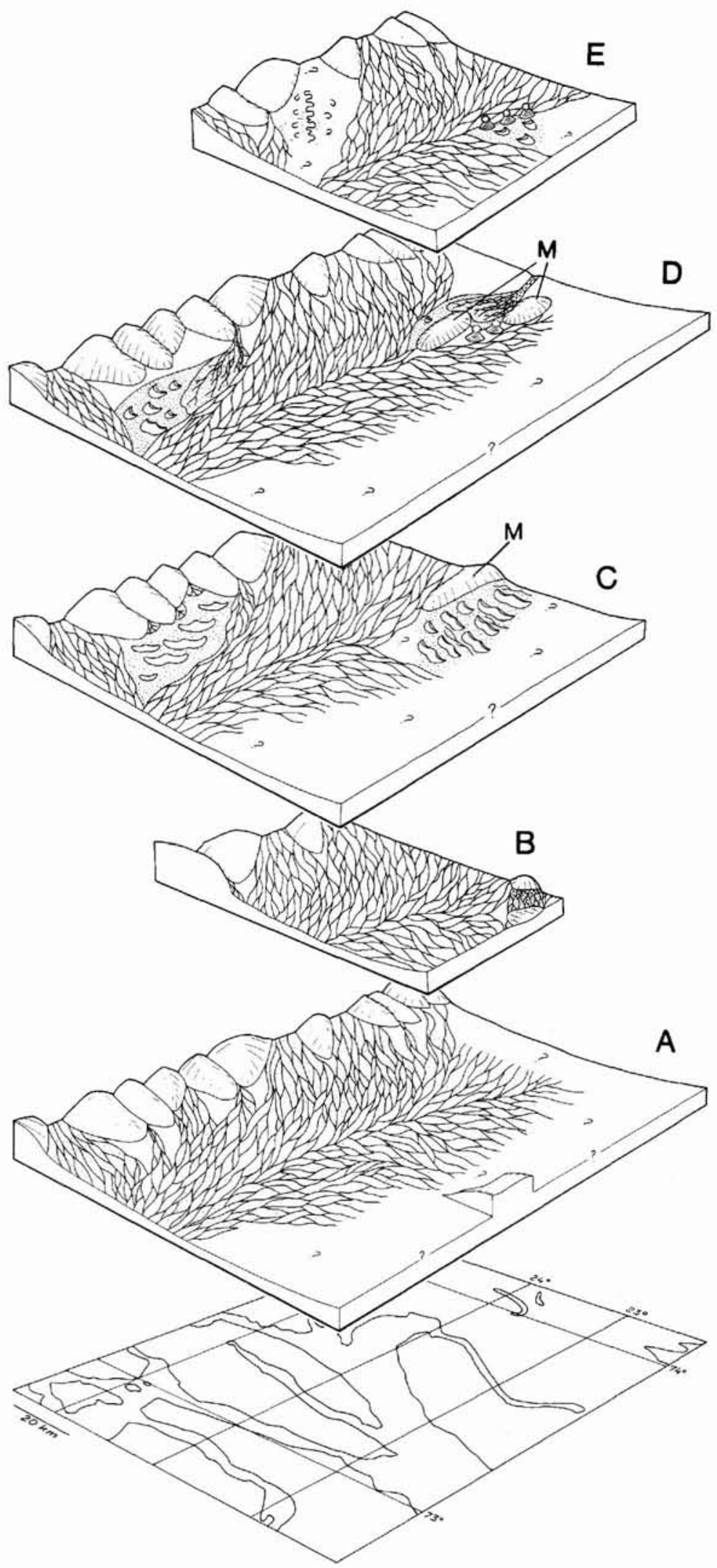




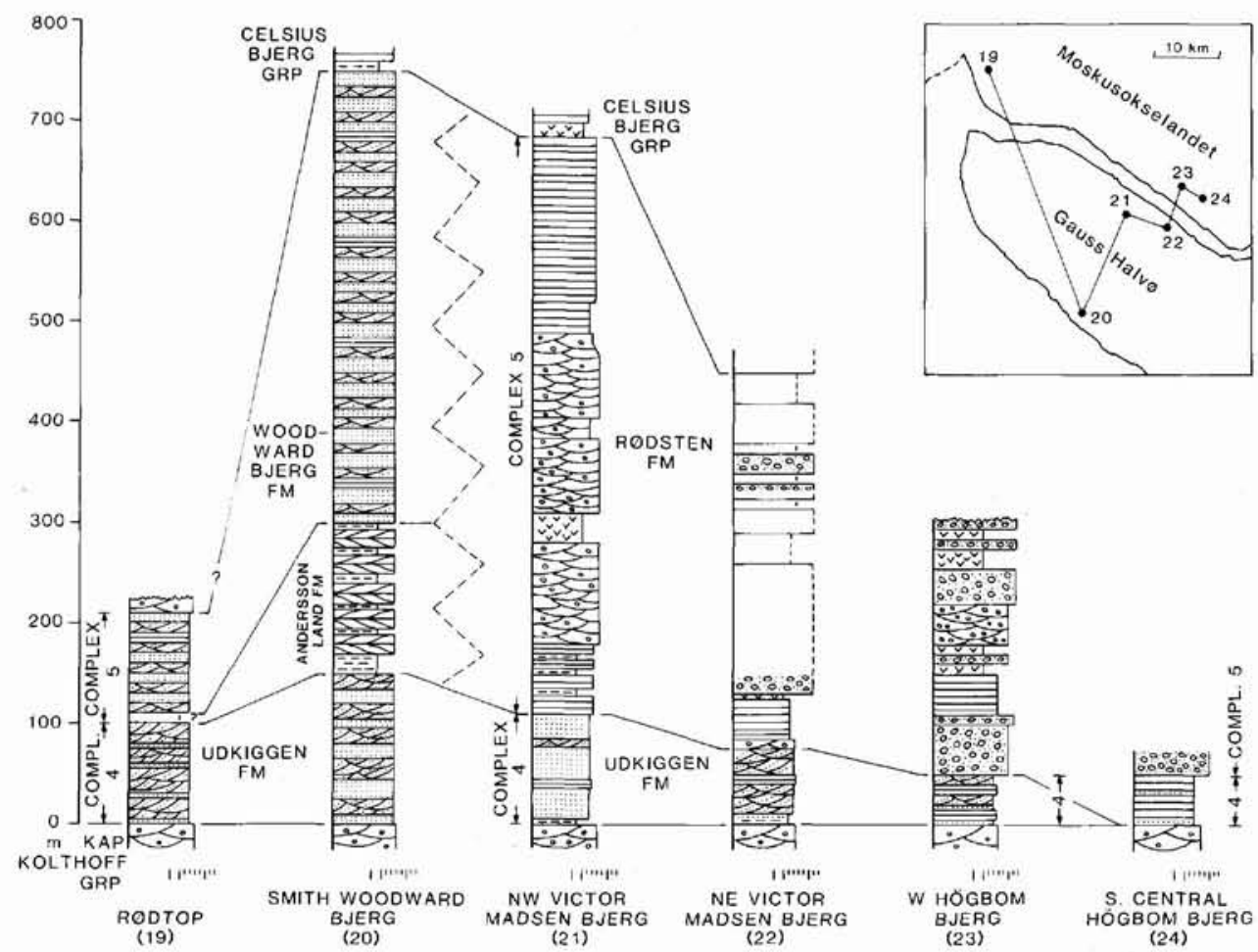

Fig. 19. Depositional complexes 4 and 5 (Kap Graah Group) from the Kap Kolthoff - Kap Graah basin stage in Moskusokselandet and Gauss Halvø. Intervals with no ground observations are indicated by dashed lines and absence of signature. For legend see Fig. 4.

nal fans with their source in the eastern borderlands of the basin.

Depositional complex 4 reflects a palaeogeography dominated by a huge erg (Udkiggen Formation) covering the main part of the basin, with terminal fan systems developed along the basin margins (Zoologdalen and Rødsten Formations) although the Rødsten system was very restricted in areal extent (Fig. 22).

\section{Depositional complex 5}

Depositional complex 5 is built up of four depositional systems represented by the Andersson Land, Woodward Bjerg, Zoologdalen and Rødsten Formations (Figs 19, 20). The rather simple picture of the preceding complex is replaced by a more intricate relationship between the systems.

The Andersson Land Formation is composed of siltstones and tabular sandstone bodies of the flood basin and meandering river associations, respectively (Figs 19, 20). The deposi-tional system is interpreted as a meander belt, and palaeocurrents indicate that the meandering river flowed southwards (Fig. 23). In the lower part of the complex, the formation is laterally extensive, exceeding $20 \mathrm{~km}$ in transverse E-W direction. In the upper part, the formation is restricted to a $c .10 \mathrm{~km}$ wide belt in the western part of the basin (Figs 19, 20). A pronounced cyclicity in the thickness variation of sandstone bodies of meandering river origin is observed; i. e. lower ordercycles $c .20 \mathrm{~m}$ thick within higher-order cycles $c .100 \mathrm{~m}$ thick. The cyclicity indicates cyclic variations in river discharge (Olsen, 1990, 1993).

The Woodward Bjerg Formation (Fig. 19, sections 19 \& 20) resembles the Udkiggen Formation, although parallel laminated aeolian sandstones are much more common, and the depositional system envisaged for this formation is an aeolian sand sheet-dominated erg with small simple dunes and only rare large compound dunes. Palaeowinds are mainly towards the SW.

The Zoologdalen Formation in complex 5 resembles the lower part of the formation, occurring in the preceding complex (Fig. 20, section 25). Palaeocurrents are SE (Fig. 23). It is interpreted as a system of terminal fans, with headwaters in the western borderlands of the basin.

The Rødsten Formation of complex 5 is strongly expanded compared to complex 4 (Figs 19, 20). The lower part consists of mainly alluvial-fan conglomerate sheets (gravelly stream association) in the east (Kap Graah and Högbom Bjerg), and mainly low sinuosity ephemeral stream deposits in the remaining part of the basin. The 
Fig. 20. Depositional complexes 4 and 5 (Kap Graah Group) from the Kap Kolthoff - Kap Graah basin stage in Gunnar Andersson Land. Intervals with no ground observations are indicated by dashed lines and absence of signature. For legend see Fig. 4.

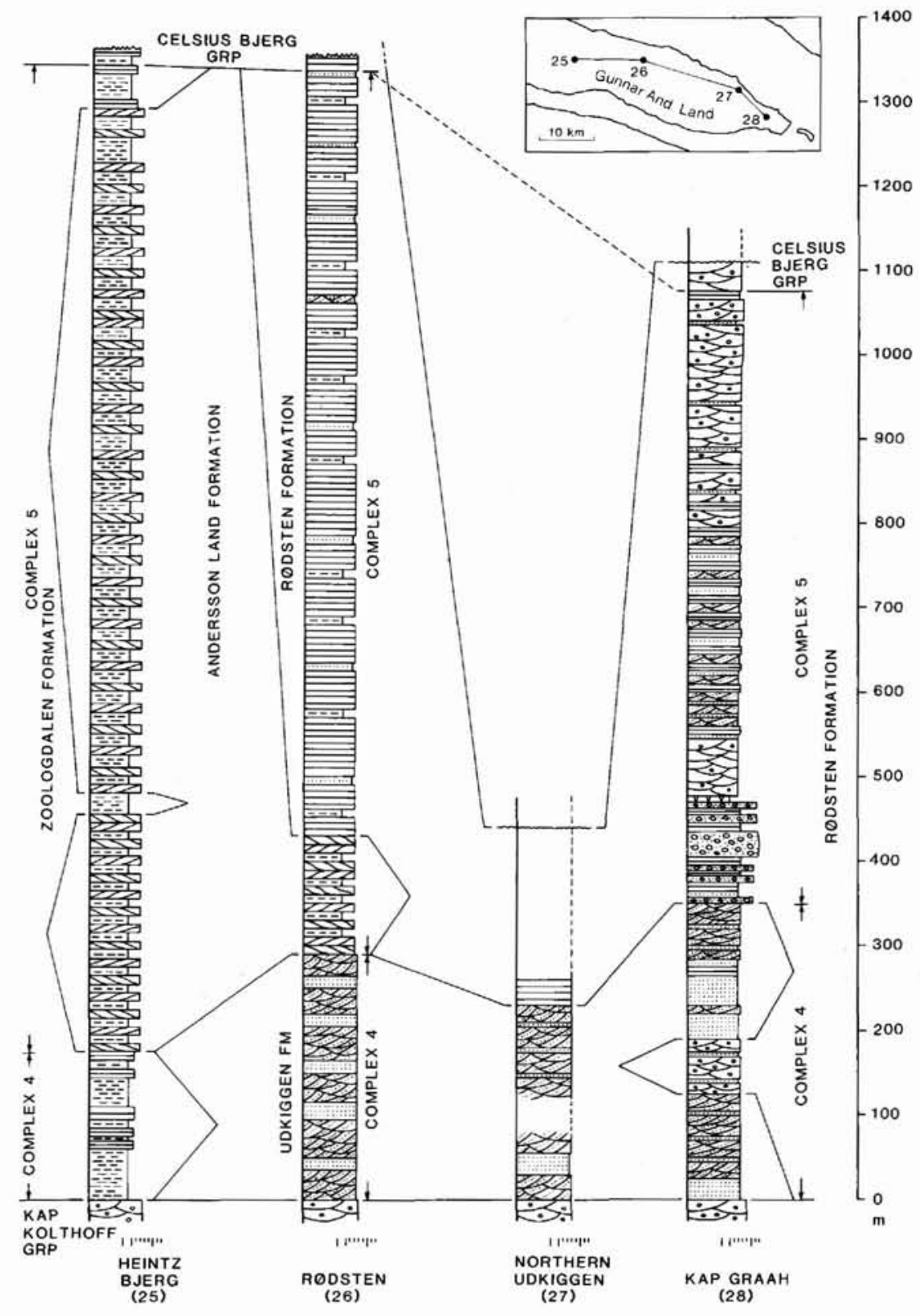

upper part of the formation consists of sandy braided river deposits with associated aeolian and ephemeral stream deposits at Kap Graah, passing down-current (west) into low sinuosity ephemeral stream deposits with flood basin and aeolian interbeds (Fig. 20, sections 2628 ); whereas in the northern part of the basin, alluvial-fan conglomerates in the east (Högbom Bjerg and NE Victor Madsen Bjerg) pass laterally to the west into sandy braided river deposits and low sinuosity ephemeral stream deposits (Fig. 19, sections 21-23). The depositional environment in general is interpreted as alluvial fans, restricted to an eastern basin margin fault scarp, passing down-current into an extensive system of terminal fans (Olsen \& Larsen, 1993b). In the southeast alluvial fan progradation is restricted to the lowermost part of the complex followed by retrogradation (Fig. 20, section 28). Palaeocurrents are directed towards the W and SW (Fig. 23).

The palaeogeographic reconstruction of the lower part of complex 5 (Fig. 24A) reflects two transverse alluvial systems (Zoologdalen and Rødsten Formations) separated by a very wide axial meander belt system (Andersson Land Formation). In the northeastern part of the area a small erg (Woodward Bjerg Formation) may have occu- 


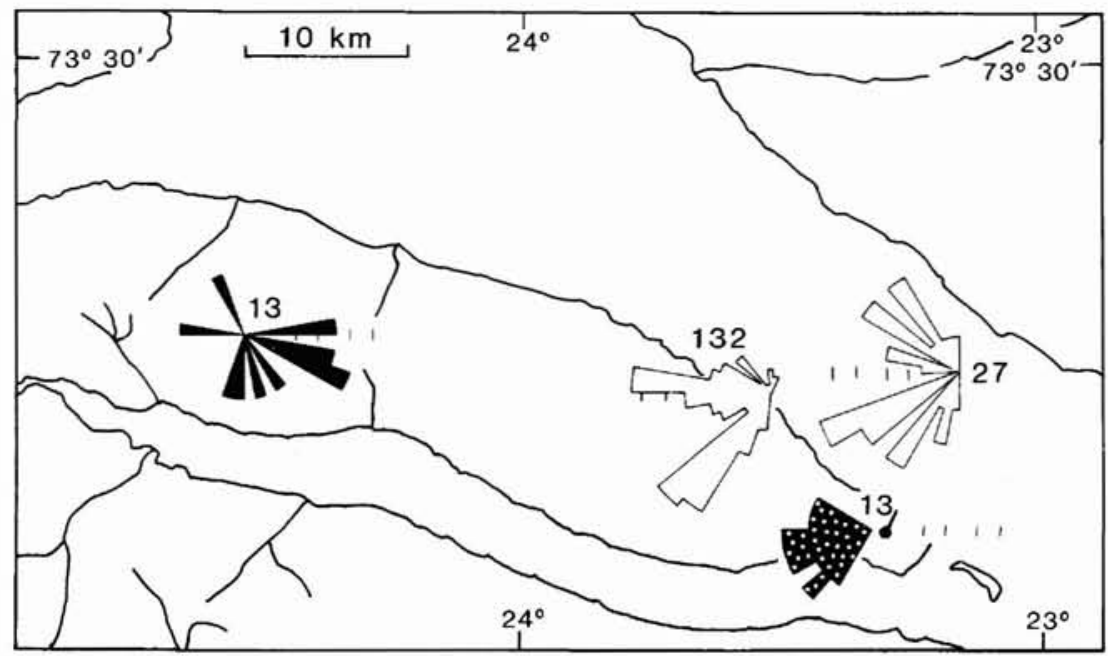

Fig. 21. Palaeocurrent and wind roses (areal plots) from complex 4; Zoologdalen Formation (solid), Rødsten Formation (spotted) and Udkiggen Formation (open). The centre of the roses indicates the localities. Indications of 5, 10, 20 and $30 \%$ of measurements are provided as well as number of measurements from each locality.

pied a position between the meander belt and terminal fans of the Andersson Land and Rødsten Formations, respectively, but this has not been confirmed by field observations.

The upper part of the complex (Fig. 24B) reflects the presence of the same depositional systems as the lower part. The meander belt, however, was narrowed considerably, occupying only a thin strip in the western part of the basin. In contrast, the Rødsten terminal fan system had prograded far towards the west and the erg (Woodward Bjerg Formation) had expanded to a considerable size.

\section{Underlying controls}

Depositional complex 3 is defined by the change from eastward drainage of the two former complexes to a symmetrical pattern with input from both west and east, and a regional palaeoslope towards the south along the central part of the basin. A more complicated palaeocurrent pattern is observed along the eastern basin margin, reflected in the southeasterly palaeocurrents in the Vergys Formation (Fig. 14) and northwestward palaeocurrents in the Sofia Sund Formation in eastern Gauss Halvø (Fig. 13). The palaeocurrent patterns indicate that an eastern basin-margin fault zone was created close to the present

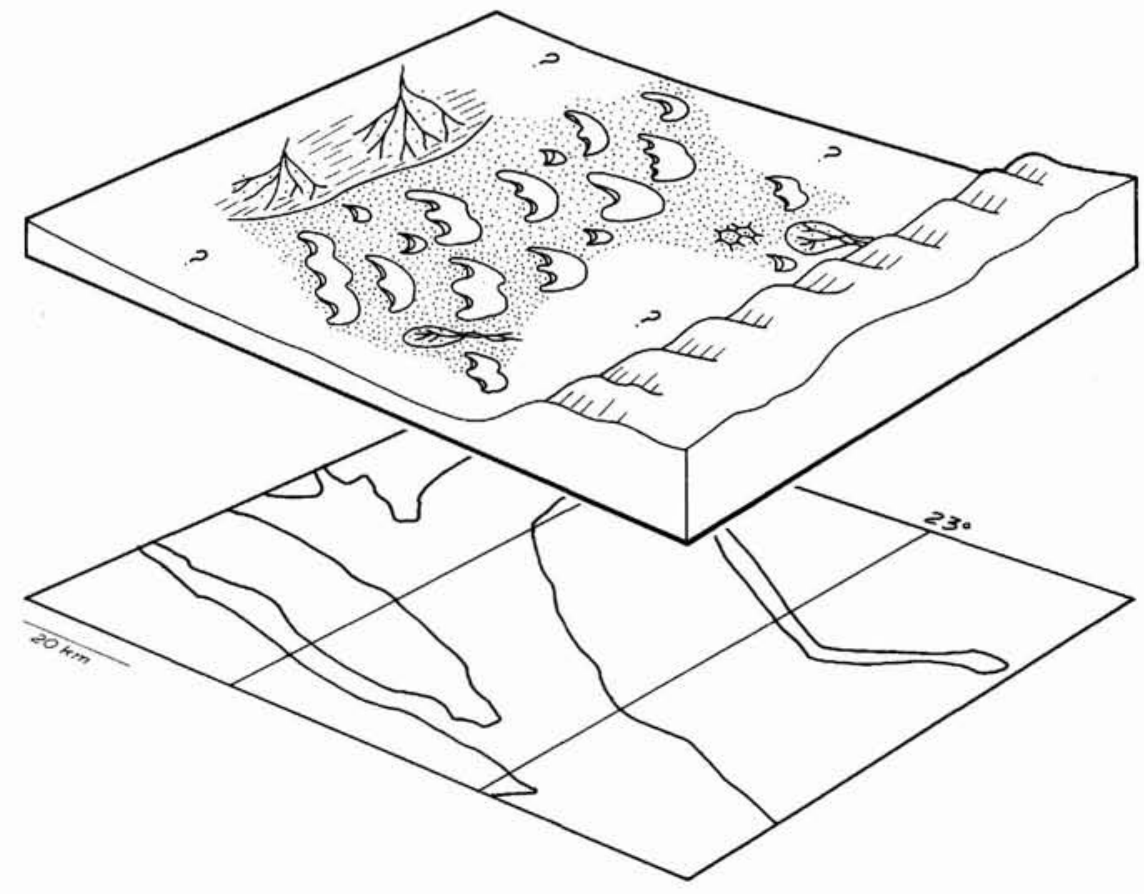

Fig. 22. Palaeogeographic reconstruction of depositional complex 4, lower Kap Graah Group. Terminal fan systems occur along the basin margins (Zoologdalen Formation in the west, Rødsten Formation in the east) draining SE and SW, respectively. The main part of the basin is occupied by the Udkiggen Formation erg. 
Fig. 23. Palaeocurrent roses from depositional complex 5 (areal plots) from the Zoologdalen Formation (solid roses in the west), Andersson Land Formation (open, central area) and Rødsten Formation (spotted, east). Localities are in the centre of the roses, if nothing else is indicated. Percentages of measurements are indicated $(5,10,20,30 \%)$ as well as number of measurements. The arrow represents measurements in the Andersson Land Formation taken from Nicholson \& Friend (1976, table 9).

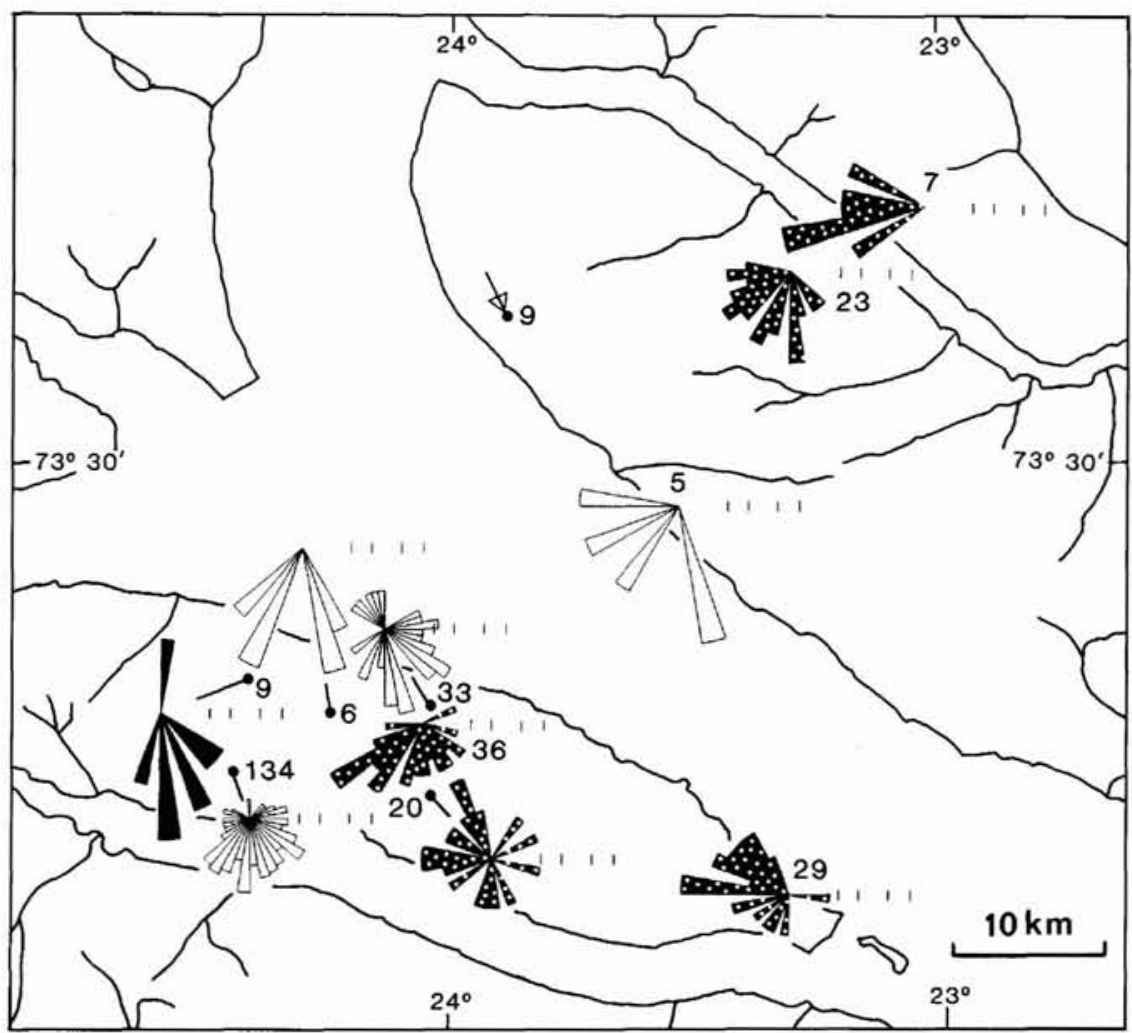

day outcrop area of the complex. The eastern boundary of the present exposed basin shows the existence of a complex strike-slip/oblique-slip fault zone, termed the Eastern Fault Zone (Larsen \& Olsen, 1991). Immediately west of this fault zone numerous angular uncon-formities occur in the Kap Kolthoff Group (Bütler, 1959; Larsen, 1990d). The development of unconformities is closely related to synsedimentary upthrusting within the Eastern Fault Zone (Larsen, 1990d) and probably also to volcanism and granite emplacement in the Kap Franklin area (Friend et al., 1983). Collectively, these lines of evidence seem to indicate that the Eastern Fault Zone was initiated as a basin margin fault zone at the onset of deposition of complex 3 and that it continued to be active during deposition of the complex.

In contrast, the Western Fault Zone exhibits very limited signs of activity during the Kap Kolthoff - Kap Graah basin stage. The Kap Kolthoff Group onlaps the underlying rocks along the fault zone and shows only weak deformation in this zone, mainly of compressional style dominated by small reverse faults with slips of only a few metres or tens of metres. It is, however, suspected that some tectonic subsidence occurred along this fault zone, also in the Kap Kolthoff - Kap Graah basin stage.

The lowermost few hundred metres of the Sofia Sund Formation commonly exhibits a colour banding in 10-30 $\mathrm{m}$ scale in green and red or reddish green units. The red units occasionally consist of ephemeral stream and aeolian deposits. The sediments in general are, however, dominated by sandy braided river deposits as elsewhere in the Sofia Sund system. The colour banding seems to indicate, that the regular climatic changes, reflected in depositional complex 2 (Ankerbjergselv Formation) continued in the early stages of complex 3 . Accordingly, the general climate in the region pro-bably was unchanged from the late Vilddal basin stage. The uplift of the eastern basin margin may have changed the local climate so that increased precipitation in this newly established highland changed the fluvial depositional systems to dominantly perennial types. A later general change in climate towards more humid conditions produced the typical Sofia Sund braid plain, and prevailed during deposition of the main part of complex 3 .

The development of the Vergys Formation probably occurred in response to an early tectonic event. This is indicated by the presence of an unconformity at the base of the formation (cf. Larsen, 1990d; Olsen \& Larsen, 1993a). A local tectonic event may have changed the local drainage pattern and formed a localized depression with development of a lake in the distal part of the Vergys Formation.

The development of the ergs represented by the Barna- 


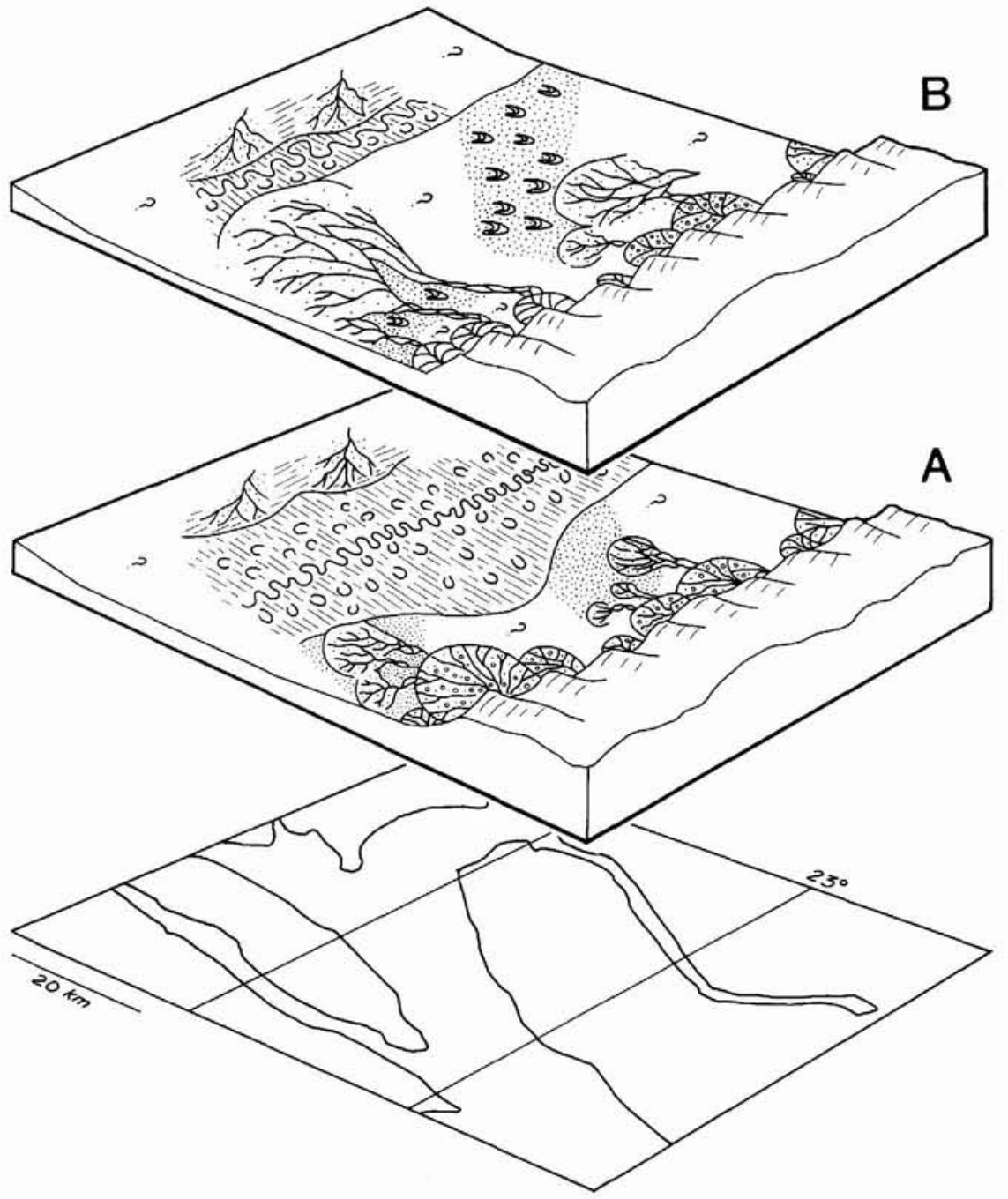

Fig. 24. Palaeogeographic reconstruction of depositional complex 5 in the Kap Graah Group. (A) Lower part of complex 5: a wide meander belt (Andersson Land Formation) and marginal alluvial fan and terminal fan systems (Zoologdalen and Rødsten Formations). A reminiscent of an erg in the form of the Woodward Bjerg Formation is probably present (densely spotted signature in the Moskusoksefjord area). The general palaeoslope is towards the south. (B) Upper part of complex 5: the meander belt of the Andersson Land Formation has narrowed in connection with an expansion of the depositional systems of the Rødsten and Woodward Bjerg Formations. Alluvial fans in the Andersson Land area without lithology signature are undocumented. The general palaeoslope is towards the south.

bas Dal and Langbjerg Formations initially suggests climatic control. However, the co-existence of the Sofia Sund braid plain seems to contradict a general climatic deterioration. The abundance of fluvial deposits in interdune areas of the Langbjerg erg and signs of damp or wet surfaces of the dunes and interdunes in the Barnabas Dal erg also strongly indicate that precipitation was relatively high. A local tectonic event in the borderlands can result in diminishment of drainage basin size or localized diversion of drainage away from the basin (Frostick \& Reid, 1987). Accordingly, reduced discharge into the basin may occur at this point, compared to the basin in general. In consequence a starvation of fluvial streams will occur and aeolian processes may dominate. However, because the precipitation in the basin may be unchanged, ephemeral wetting of dune and interdune surfaces is expected and local ephemeral streams may develop in the interdune lows.

Local tectonics in the borderlands are also favoured to explain the development of the terminal fan systems of the Snehvide and Rødebjerg Formations. As seen in the Barnabas Dal Formation, these two depositional systems reflect considerably lower discharge, compared to the basin in general. In addition, a volcanic centre in Moskusokselandet and the 'Moskusoksefjord inlier' nearby seems to have diverted the drainage of the Snehvide terminal fan to the west of the inlier.

The creation of the erg of the Madsen Bjerg Formation may also have been partly controlled by the volcanic centre in Moskusokselandet. The formation crops out immediately south of the volcanic rocks and the Madsen Bjerg erg could, accordingly, be developed in a zone behind the volcanoes, sheltered from southward flowing rivers of the Sofia Sund Formation. However, reduced discharge from the east probably also contributed to the development of the erg, and this could be explained by tectonism influencing the size of the local drainage area.

Finally, the meander belt of the Midnatspas Formation 
could be a response to a reduced local slope, causing a rapid change in sinuosity and channel pattern, as experimentally shown by Schumm \& Khan (1972). A climatic change towards more arid conditions would probably also result in reduced discharge and transition from braided to meandering rivers (Leopold \& Wolman, 1957). However, an abundance of plant material in this formation seems to point against arid conditions. An alternative explanation may be reduced rejuvenation in the source terrain. This would result in increased chemical weathering and thus increased production of clay minerals (Press \& Siever, 1974), which would eventually result in a change to mixed load meandering rivers (cf. Schumm, 1981).

In conclusion, the palaeogeography of depositional complex 3 was mainly structurally controlled. The creation of a symmetrical basin was caused by the development of the Eastern Fault Zone. Later, local tectonism strongly affected the development of formations, i.e. the development of numerous unconformities close to the Eastern Fault Zone, and the reduction of drainage basins and thus discharge reduction of rivers entering the basin.

The abrupt change from braid plain dominance in depositional complex 3 to a palaeogeography dominated by a basin scale erg (Udkiggen Formation) of complex 4 indicates a dramatic change in climate to arid conditions. No signs of tectonism are associated with the development of the erg except for subdued folding during deposition of complex 4 , believed to exert no control on deposition (Olsen \& Larsen, 1993b). The climatic change is interpreted to be of regional character.

The disappearance of the erg at the transition to complex 5 initially calls for a climatic explanation. However, Olsen \& Larsen (1993b) have shown that tectonism probably exerted the primary influence on the palaeogeography. The underlying control is interpreted as a tectonic uplift of the eastern part of the basin, probably associated with rejuvenation of parts of the borderlands. The latter either caused an increased local precipitation or resulted in local expansion of drainage basin areas giving rise to progradation of the alluvial fans and terminal fans of the Rødsten Formation. At Högbom Bjerg alluvial fans continued to possess a considerable size throughout deposition of complex 5, whereas the alluvial fan at Kap Graah prograded in the early phase but rapidly diminished in size in the later phase. Applying the ideas of Blair (1987a) this may be explained by continued high rate of tectonic activity in the Kap Graah area, while alluvial fan deposition kept pace with a relatively slower rate of tectonic subsidence in the Högbom Bjerg area. The longterm expansion of the Rødsten and Woodward Bjerg Formation systems during deposition of complex 5 was a result of the capture of the meandering river system
(Andersson Land Formation) on the western flank of a rising anticline, combined with uplift of the eastern basin margin, as observed in eastern Gunnar Andersson Land (Olsen \& Larsen, 1993b). The depositional systems of the Rødsten and Woodward Bjerg Formations kept pace with the folding as seen by the presence of these formations on both sides of the anticline.

The establishment of the meandering river system (Andersson Land Formation) is explained by tectonism in the borderlands to the north of the basin. An increase in the size of drainage basin for fluvial inflow in the north may have triggered the establishment of the river. Alternatively, uplift of the northern borderlands may have resulted in local increase in precipitation.

Although general climatic changes do not seem to be responsible for either the establishment of the meander belt or the successive narrowing of this system, minor cyclic variations in precipitation is apparently reflected in the river discharge variations (cyclic variation in sandstone body thickness). These variations are interpreted in terms of Milankovitch type climatic oscillation (Olsen, 1990, 1993).

\section{Celsius Bjerg basin stage: northward draining alluvial plains and lakes}

The Celsius Bjerg basin stage (Famennian), represented by the up to $1550 \mathrm{~m}$ thick Celsius Bjerg Group, succeeds the Kap Kolthoff - Kap Graah basin stage with sub-regional unconformities (Fig. 25) and is distinguished by northward drainage, in contrast to the southward drainage of the preceding basin stage. The basin fill is built up of five depositional complexes (6-10) of which several are composed of only one depositional system (Figs 2, 26).

\section{Depositional complex 6}

Depositional complex 6 is composed of two depositional systems, represented by the Agda Dal Formation and the succeeding Elsa Dal Formation (Figs 2, 26). The Agda Dal Formation unconformably overlies a very irregular topography in the eastern part of Gauss Halvø, and basal angular unconformities are observed at several localities, mainly in the eastern part of the basin. An upward transition from low sinuosity stream deposits mainly of the ephemeral stream association (Agda Dal Formation) to deposits mainly of the sandy braided river association (Elsa Dal Formation) is observed although braided river deposits locally also dominate the Agda Dal Formation. In the eastern part of Gauss Halvø channelshaped conglomerates locally form substantial parts of 


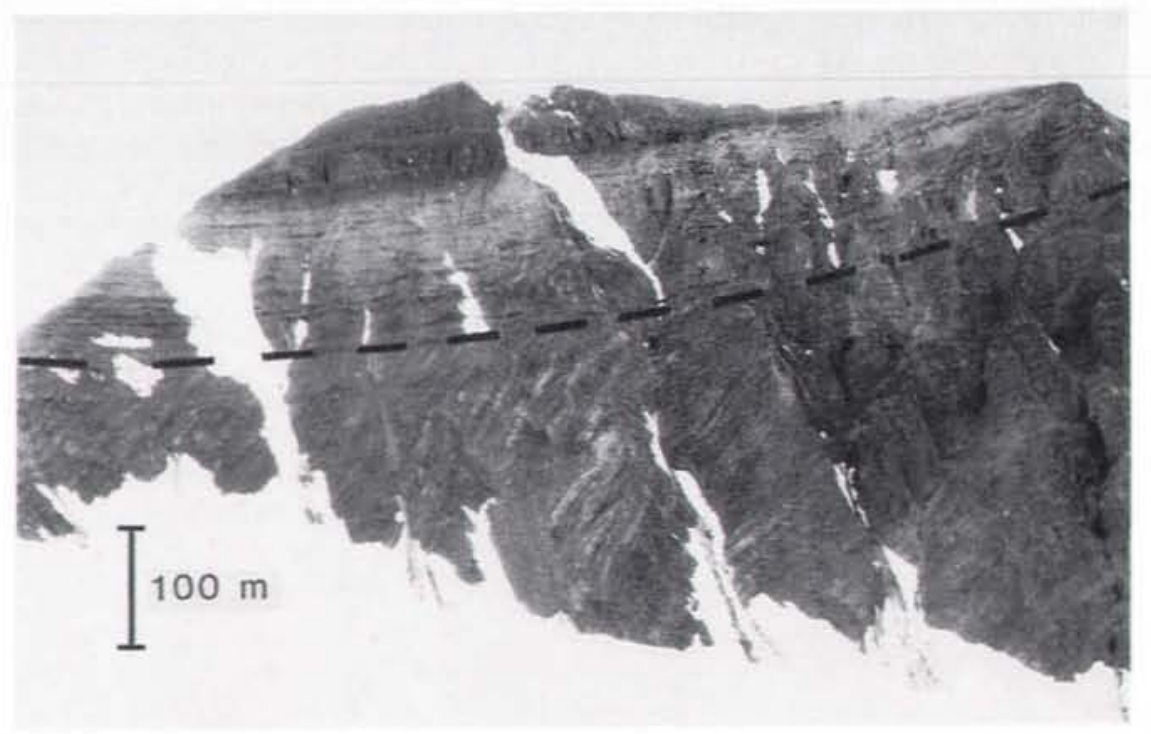

Fig. 25. Angular unconformity defining the lower boundary of the Celsius Bjerg basin stage. Sediments of the Celsius Bjerg Group unconformably overlie sediments of the Kap Kolthoff Group. Locality: Bøggild Bjerg in Gauss Halvø, viewed from the east. (Photograph by P.-H. Larsen.)

the complex. Palaeocurrents in the two systems are directed northwards (Fig. 27).

Complex 6 indicates initial valley incision (base of the Agda Dal Formation) causing a very irregular topography at least in the region of eastern Gauss Halvø. After infilling of the incised valleys a featureless alluvial plain was developed (Fig. 28A). The overall distribution of palaeocurrents (Fig. 27) indicates a component of drainage towards the axis of maximum subsidence (Larsen, 1990 b,d), i.e. along a N-S line through Celsius Bjerg, Kap Graah, Smith Woodward Bjerg and Victor Madsen Bjerg. The coarseness of clastic deposits in the easternmost outcrops east of Agda Dal indicates a proximity to a basin margin. The westernmost outcrops on Heintz Bjerg in Gunnar Andersson Land, in contrast, are very fine grained. The western basin margin, accordingly, was situated at some distance further west. Thus the basin configuration during deposition of the Agda Dal and Elsa Dal Formations was asymmetrical with an axis displaced towards the east.

\section{Depositional complex 7}

This complex is built up of only one system, the alluvial plain of the Aina Dal Formation, which is composed of sandstone bodies and siltstones of the meandering river and flood basin associations in the lower part with an upward transition to sandy and silty ephemeral (meandering) stream deposits and flood basin mudstones (Fig. 26). Palaeocurrent directions are northwards (Fig. 29). Brief investigations of the down-current outcrops on Victor Madsen Bjerg showed the existence of mainly sheetflood deposits of very fine grained sandstone in the lower part overlain by flood basin siltstones. Palaeocurrents from this part of the formation are also towards the north but with a high spread and these deposits are interpreted as representing a terminal flood basin tract.

Complex 7, accordingly, represents a northward draining alluvial plain with meandering rivers terminating in a flood basin (Fig. 28B). The rivers were initially characterized by perennial flow with a gradual change towards increased ephemerality. The palaeocurrent distribution (Fig. 29) is broadly similar to the underlying complex 6. However, the axis of the basin seems to be displaced further towards the east.

\section{Depositional complex 8}

Complex 8 (Wimans Bjerg Formation) is a succession of two types of depositional systems, regularly alternating in units a couple of metres thick. The depositional systems are dominated by brecciated mudstones of the flood basin association and laminated siltstones of the lacustrine association, respectively (Fig. 26), indicating featureless mud flats periodically flooded by ephemeral lakes (Fig. 28C). A pronounced cyclicity in the thickness of lacustrine units (lower-order cycles averaging $3.6 \mathrm{~m}$ within higher-order cycles averaging $18.7 \mathrm{~m}$ ) observed in the central part of the basin indicates cyclic changes in the frequency and duration of lake expansion (Olsen, 1993). The centre of the system, as shown by the thickness maximum of the formation, was situated between Stensiö Bjerg and Victor Madsen Bjerg (Larsen, 1990 b,d). 

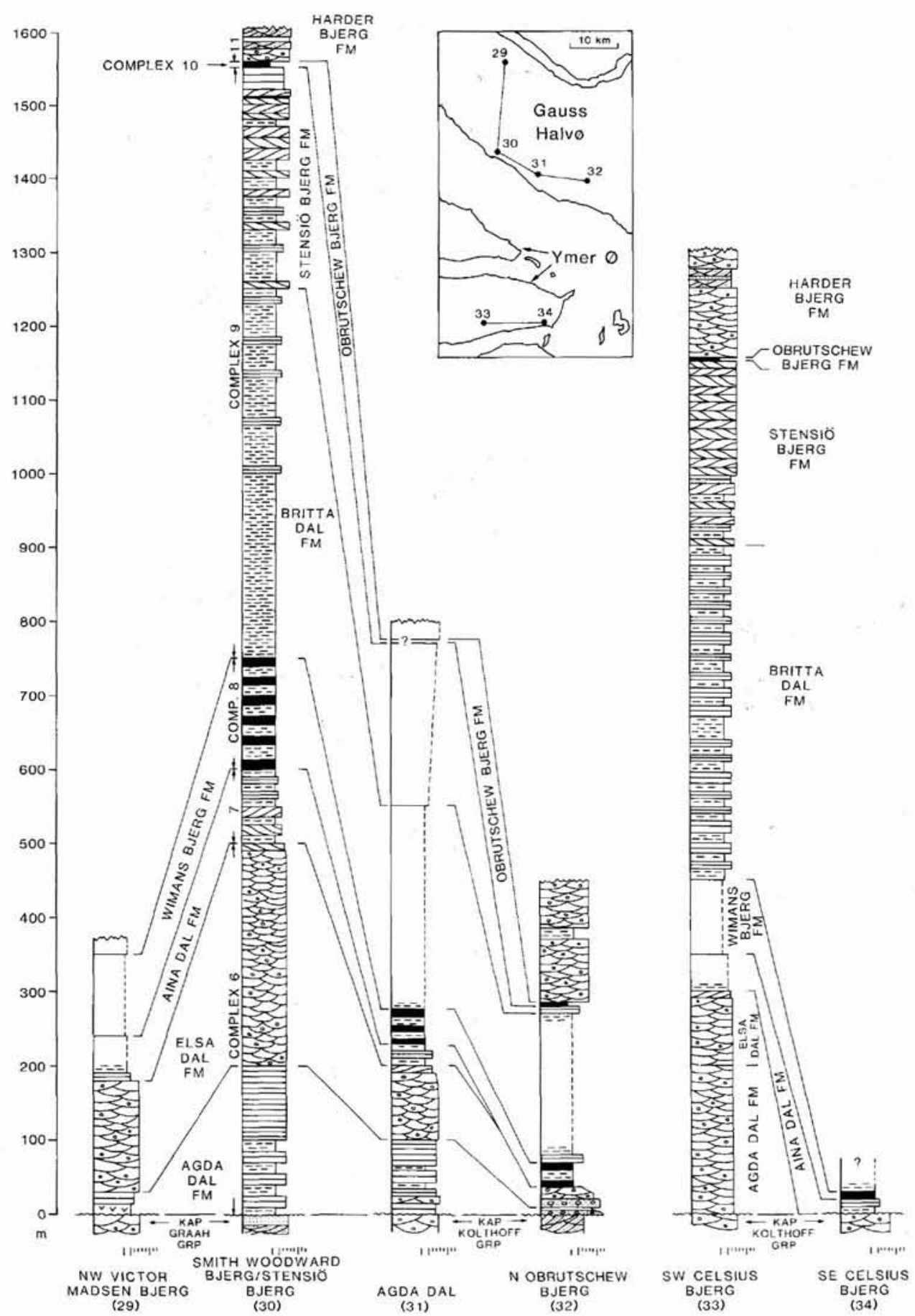

Fig. 26. Depositional complexes 6-10 (Celsius Bjerg Group) from the Celsius Bjerg basin stage, and the succeeding complex 11 of the Harder Bjerg basin stage (Harder Bjerg Formation) in Gauss Halvø and southeastern Ymer $\emptyset$. Intervals with no ground observations are indicated by dashed lines and lack of signature. For legend see Fig. 4. 


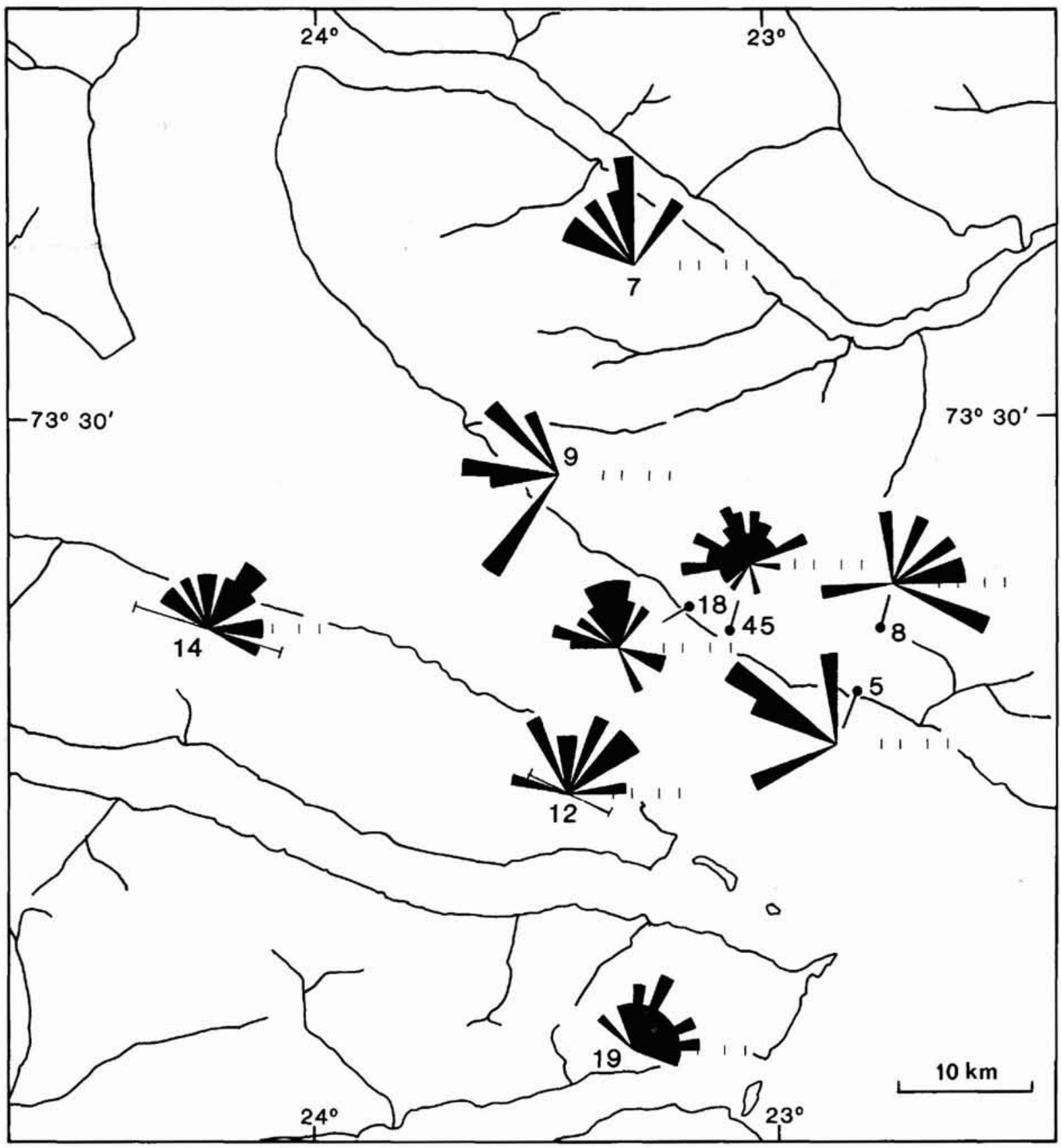

Fig. 27. Palaeocurrent roses for depositional complex 6, the Agda Dal and Elsa Dal Formations taken together. The localities are indicated by dots or by the centre of the roses, except where a bar is shown. This indicates that measurements from several localities along the bar contributed to the rose diagram. Percentages of measurements are indicated $(5,10,20,30 \%)$, as well as number of measurements.

\section{Depositional complex 9}

Complex 9 is composed of two depositional systems, represented by the Britta Dal and the succeeding Stensiö Bjerg Formations. The Britta Dal system resembles the upper part of the Aina Dal system. It is composed mainly of flood basin mudstones with ephemeral meandering stream sandstones increasing in abundance upwards (Fig. 26). A pronounced colour banding (red and green) is characteristic of the system; each red-green 'couplet' 
Fig. 28. Palaeogeographic reconstructions of the Celsius Bjerg basin stage. (A) Depositional complex 6: northward draining alluvial plain (Agda Dal and Elsa Dal Formations). The NWdraining streams in the southeastern part of the basin are speculative. (B) Depositional complex 7: alluvial plain with northward draining meandering rivers (Aina Dal Formation). (C) Depositional complex 8: mud flat/ephemeral lake environment (Wimans Bjerg Formation). (D) Depositional complex 9: alluvial plain with northward draining meandering rivers (Britta Dal and Stensiö Bjerg Formations). It is uncertain if the NW draining rivers, indicated in the eastern part of the basin, actually existed. (E) Depositional complex 10: huge anoxic lake (Obrutschew Bjerg Formation).

attaining a thickness of $c .20 \mathrm{~m}$ in the central part of the basin. The Stensiö Bjerg Formation transitionally succeeds the Britta Dal Formation, i.e. flood basin and ephemeral stream deposits are gradually replaced upwards by sandstones of the meandering river association with minor flood basin mudstones (Fig. 26).

The areal distribution of palaeocurrent measurements in complex 9 is insufficient to provide a detailed picture of the drainage pattern. At Celsius Bjerg and Stensiö Bjerg palaeocurrents trend north-northeastwards (Fig. 30). Depositional complex 9, accordingly, records a return to roughly northward draining alluvial plain conditions (Fig. 28D). Initially the rivers were characterized by ephemeral discharge. Gradually, however, the rivers were transformed into perennial meandering rivers. The maximum thickness of the complex is observed around Stensiö Bjerg and like the two previous complexes the basin axis was directed $\mathrm{N}-\mathrm{S}$.

\section{Depositional complex 10}

The uppermost depositional complex in the Vilddal basin stage is entirely built up of the Obrutschew Bjerg Formation, which is a lacustrine depositional system mainly composed of black shales and limestones with local grey silty mudstones (Fig. 26). Outcrops are restricted to the eastern part of the basin. The general lack of sedimentary structures except parallel lamination suggests a lake depth much deeper than the thickness of the formation (4-6 m). The sparse outcrops available indicate a considerable lake size with a minimum extent stretching from Celsius Bjerg in the south to Stensiö Bjerg in the north and northern Obrutschew Bjerg in the east (Fig. $28 \mathrm{E})$. The general lack of coarse clastic sediments indicates that the coastline was situated at some distance from the outcrop localities. The lake, accordingly, seems to be developed as a basin-wide feature.

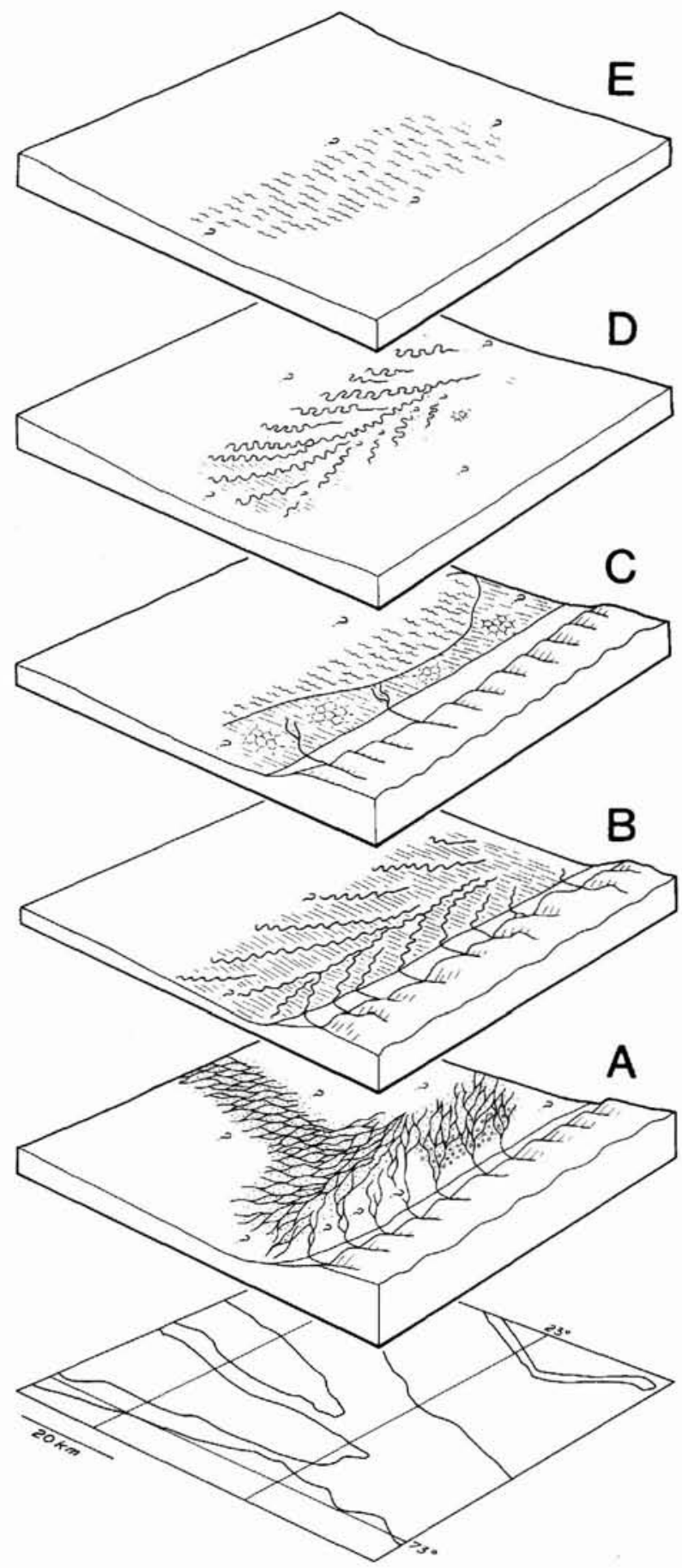

\section{Underlying controls}

A reversal of palaeoslope and thus drainage towards the north marks the end of the Kap Kolthoff - Kap Graah basin stage and the establishment of the Celsius Bjerg basin stage. The palaeoslope reversal was caused by uplift of the southern part of the basin relative to the northern part. The Devonian basin fill exhibits strong 


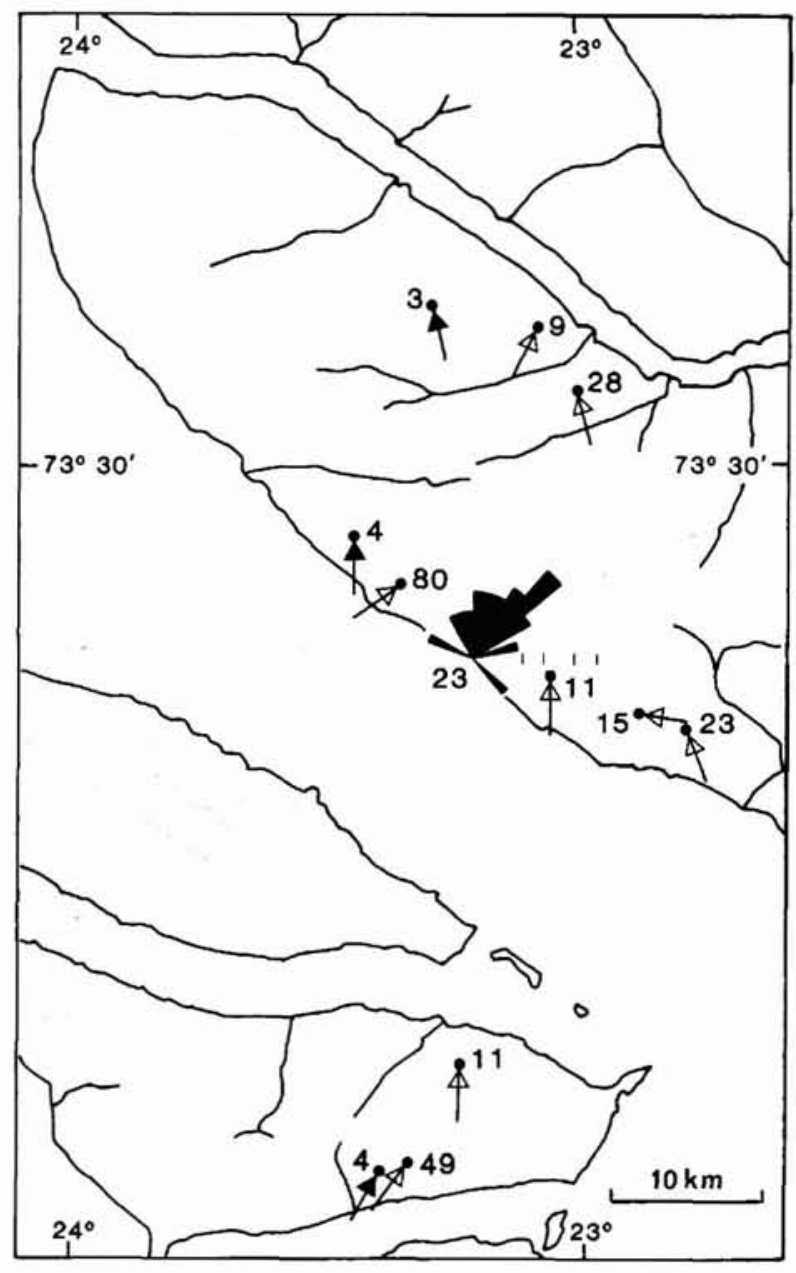

Fig. 29. Palaeocurrents from depositional complex 7 (Aina Dal Formation). The centre of the roses indicates the localities. Number of measurements and percentage of measurements (5. $10,20,30 \%)$ are shown. The rose diagrams are areal plots. Localities with less than 5 measurements are represented by solid arrows. Measurements from Nicholson \& Friend (1976, fig. 52) are indicated by open arrows.

deformation in the southern part around Kong Oscar Fjord where folds occur in association with several thrusts (e.g. Bütler, 1957; Fig. 1B); a prominent example is shown by Marcussen et al. (1988) from Rødebjerg. These deformations trend in a similar north-south direction as the more gentle folds further north. It is tentatively suggested that these strong deformations are closely related to the deformation taking place in complex 4 and 5 , but the folding and uplift seems to have accelerated at the transition to the Celsius Bjerg stage, probably in connection to the development of thrusts. Folding continually affected deposition of the Celsius Bjerg Group shown by the changing palaeocurrent and isopach patterns in the constituent complexes.

The lowermost complex 6 reflects an apparent climatic change from relatively arid conditions with a dominance of ephemeral streams (Agda Dal Formation) to more humid conditions with braided rivers (Elsa Dal Formation) in Gauss Halvø and Gunnar Andersson Land. At Obrutschew Bjerg this transition occurs along with a change to conglomeratic deposits. Further south at $\mathrm{Cel}-$ sius Bjerg both systems are composed of sandy braided river deposits exhibiting no indications of climatic change. Accordingly, the local change in climate may have been induced by local tectonic uplift of the northern part of the eastern basin margin, changing the local drainage basin areas or precipitation rates.

The rapid transition to meandering rivers of the succeeding complex 7 (lower Aina Dal Formation) could reflect an abrupt change in channel pattern combined with a decrease in valley slope, as experimentally shown by Schumm \& Khan (1972). The change in slope may be a function of tectonism. Syn-sedimentary tectonism is suggested by the displacement of the location of maximum deposition, which is interpreted to be related to subsidence. Alternatively the change may be a function of reduced tectonic activity in the borderlands. This would result in a reduced relief and thus a dominance of chemical weathering over physical weathering. An increased production of clay would be the result and thus cause a change of the sediment load available. Accordingly the rivers could change from sandy load (braided) types to mixed load (meandering) types (cf. Schumm, 1981). The change from dominantly sandy deposits in the Elsa Dal system to sediments rich in siltstones and mudstones in the Aina Dal system seems to support this latter alternative.

The gradual change from perennial rivers to ephemeral streams within the Aina Dal system was most likely controlled by climatic change towards decreased precipitation. The aridification continued and resulted in the development of the Wimans Bjerg Formation, representing ephemeral lake and mud flat conditions. Flooding resulted in ephemeral lake expansion during periods of relatively high precipitation, and lake contraction during periods of low precipitation. These cyclic climatic changes were probably controlled by Milankovitch type climatic forcing (Olsen, 1993). The establishment of the Wimans Bjerg systems may, however, also be controlled by tectonism. If the basin changed from through-flow drainage to a closed basin due to tectonic closure of an outlet, heavy rainstorms probably would result in rapid lake expansion, and lakes would persist for prolonged periods and prohibit the development of fluvial channels. Accordingly the establishment of the Wimans Bjerg For- 
Fig. 30. Palaeocurrent roses (areal plots) of depositional complex 9, the Britta Dal and Stensiö Bjerg Formations taken together. Centre of the roses indicates the locality. Number of measurements is indicated.

Percentages of measurements for the intervals on rose diagrams are also indicated $(5,10,20$, $30 \%)$.

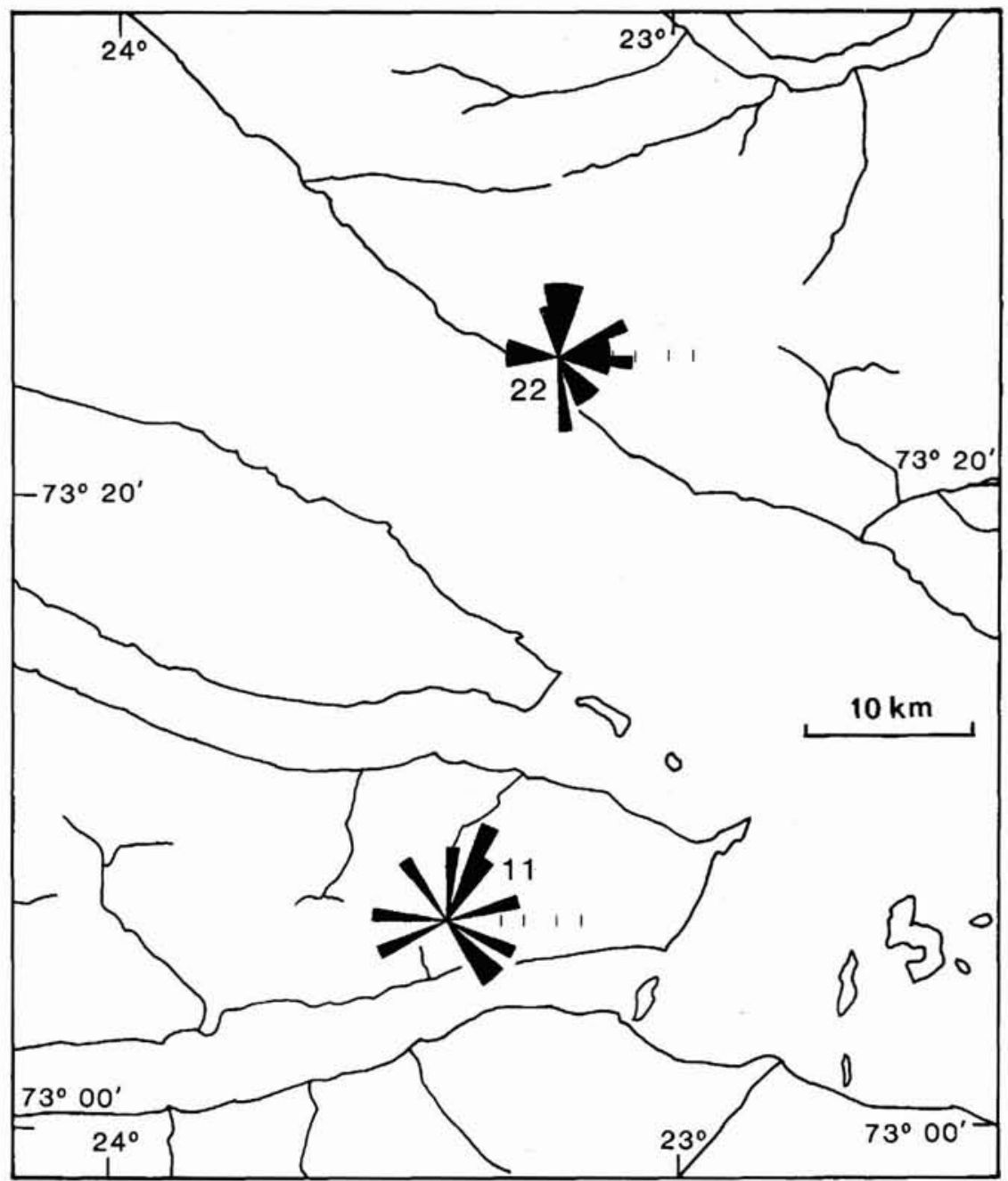

mation may be a function of both tectonism and climatic change.

The boundary between depositional complex 8 and complex 9 is transitional in character. Flood basin mudstones are similar and dominant on both sides of the boundary, but lacustrine siltstones are generally replaced by ephemeral stream deposits in the Britta Dal Formation. This may support the suggestion of a closed basin during deposition of the Wimans Bjerg Formation, and a tectonic event at the transition between complex 8 and 9 may have caused renewed through-flow in the basin. A gradual increase in precipitation is indicated by the upward increase of ephemeral stream deposits in the Britta Dal system. This climatic change was superimposed on short-term, probably Milankovitch type, climatic cyclicity recorded by the colour banding. A general improvement of the climate towards even more humid conditions is reflected by the gradual establishment of perennial meandering rivers of the Stensiö Bjerg system. A slight change towards drier conditions may be reflected in the upper part of that system by the presence of sheetflood deposits in the down-current part of the fluvial system. This may, however, also reflect a change in slope and thus represent a precursor of the succeeding lacustrine complex.

The lacustrine Obrutschew Bjerg Formation with its large areal extent, low variation in thickness and large inferred lake depth probably was deposited due to a major tectonic event closing the outlet from the basin and reflected in the boundary between depositional complex 9 and 10 . However, a humid climate with sufficient water supply or limited evaporation may have supported the formation of the lake. 


\section{Harder Bjerg basin stage: southwestward draining alluvial plains and associated aeolian systems}

The Celsius Bjerg basin stage is succeeded by the Harder Bjerg basin stage, represented by the up to $200 \mathrm{~m}$ thick Harder Bjerg Formation (complex 11, Figs 2, 26). This is the final stage in the evolution of the Devonian basin; at least the last phase represented in the area. The age of the deposits is, however, unknown, and a Carboniferous age cannot be ruled out. The formation consists of a lower part, a few tens to $100 \mathrm{~m}$ thick, of cross-bedded sandy braided river deposits overlain by alternating aeolian, ephemeral stream and braided river deposits. The formation exhibits a rather pathy preservation as mountain top covers (Fig. 1B) and the rocks are very poorly exposed. Accordingly, no detailed work was carried out. Sparse palaeocurrent data obtained from the braided river deposits at Celsius Bjerg indicate, however, a drainage towards SW in contrast to the general northward drainage of the fluvial units beneath.

Although the observations from the Harder Bjerg Formation are sparse the southwestward palaeocurrents seem to imply a major tectonic event after deposition of the Obrutschew Bjerg Formation. However, also a climatic change seems to be involved, reflected in the abundance of aeolian deposits in the Harder Bjerg Formation. The boundary between complex 10 and 11 is suspected to be an unconformity surface and seems to represent a tectono-stratigraphic boundary separating the Celsius Bjerg basin stage from a younger basin stage. More work should, however, be carried out in the study area and south of Rudbeck Bjerg on Geographical Society $\emptyset$ (Figs $1 \mathrm{~B}, 3$ ), where larger outcrops of the formation are suspected to occur (Olsen \& Larsen, 1993a).

\section{Comparison with early ideas of basin evolution}

Early suggestions of the basin type and evolution were put forward by Bütler (1935a, b, 1959), Haller (1970, 1971 ) and Friend et al. (1983). Bütler (1935a, 1959) recognized a sequence of tectonic events, which he regarded as distinct and producing synchronous effects in different parts of the basin. Bütler (1935a, b, 1959) defined the Hudson Land phases I-IV and the subsequent Ymer $\varnothing$ phase. The Hudson Land phase I was defined around the 'Moskusoksefjord inlier' by the supposed presence of an unconformity in the rocks now regarded as the Vilddal Group. Phase II was defined by the unconformity between the Vilddal Group and the Kap Kolthoff Group around the 'inlier'. Hudson Land phase III was defined in the Ankerbjergselv area and based on the strong deformation of the Kap Kolthoff Group (Vergys
Formation) in this area. Phase IV was indicated by the folding of the Kap Graah Group and development of an angular unconformity at the base of the Celsius Bjerg Group at Sederholm Bjerg, correlatable to the unconformity at Bøggild Bjerg (Fig. 25). Finally the Ymer $\varnothing$ phase was defined at Gauss Halvø as the gentle folding after deposition of the Celsius Bjerg Group. It was regarded as post-Devonian without direct genetic relationship to the Hudson Land phases. The investigations by Larsen (1990d) and Olsen \& Larsen (1993b) seem to indicate that the Hudson Land phases are parts of a continuum of compressional deformations in a strike or oblique-slip tectonic regime. The Ymer $\emptyset$ phase seems to be genetically closely related to the Hudson Land phases and to have started in the Late Devonian during deposition of complex 4, prior to the Hudson Land phase IV (Fig. 31). Accordingly, a very strict distinction between the Hudson Land phases and the Ymer $\emptyset$ phase is probably artificial.

Haller $(1970,1971)$ adopted the ideas of Bütler and speculated on the type of basin, which he suggested as a down-flexed crustal welt oriented NW-SE. The N-S trending boundary faults now recognized (e.g. Friend $e t$ al., 1983; Larsen \& Bengaard, 1991; Larsen \& Olsen, 1991) do not confirm the ideas of Haller.

Friend et al. (1983) suggested two main Devonian basin stages, the so-called Vilddal Basin and Gauss Ba$\sin$. In the Vilddal Basin a N-S trending fault c. $50 \mathrm{~km}$ west of the western boundary of the exposed basin was interpreted to be active, whereas no eastern boundary fault existed. The sediments, now defined as the Vilddal Group, were, according to Friend et al. (1983), deposited during this stage (excluding the Solstrand Formation in the western part of the basin, regarded by them as part of their Kap Kolthoff Supergroup). Drainage was directed towards the east. This picture is in general agreement with the basin configuration depicted in this paper for the Vilddal basin stage. However, in line with the ideas of Larsen \& Bengaard (1991), it is suggested that the Western Fault Zone was active and acted as a (sub-) basin boundary fault.

The Gauss Basin developed after the so-called Kap Franklin Deformation, locally recognized in the Kap Franklin area (Friend et al., 1983). This basin was defined as a symmetrical $\mathrm{N}-\mathrm{S}$ oriented basin with longitudinal drainage, mainly as a braid plain with input from both west and east. Two fault zones were active as basin boundary faults, termed the 'Kong Oscars Fjord - Nordfjord hypothetical fracture zone' and the 'Kap Franklin Canning Land hypothetical fracture zone'. These two faults conform more or less with the Western Fault Zone and the Eastern Fault Zone, respectively, as defined by Larsen (1990d). According to Friend et al. (1983) these 


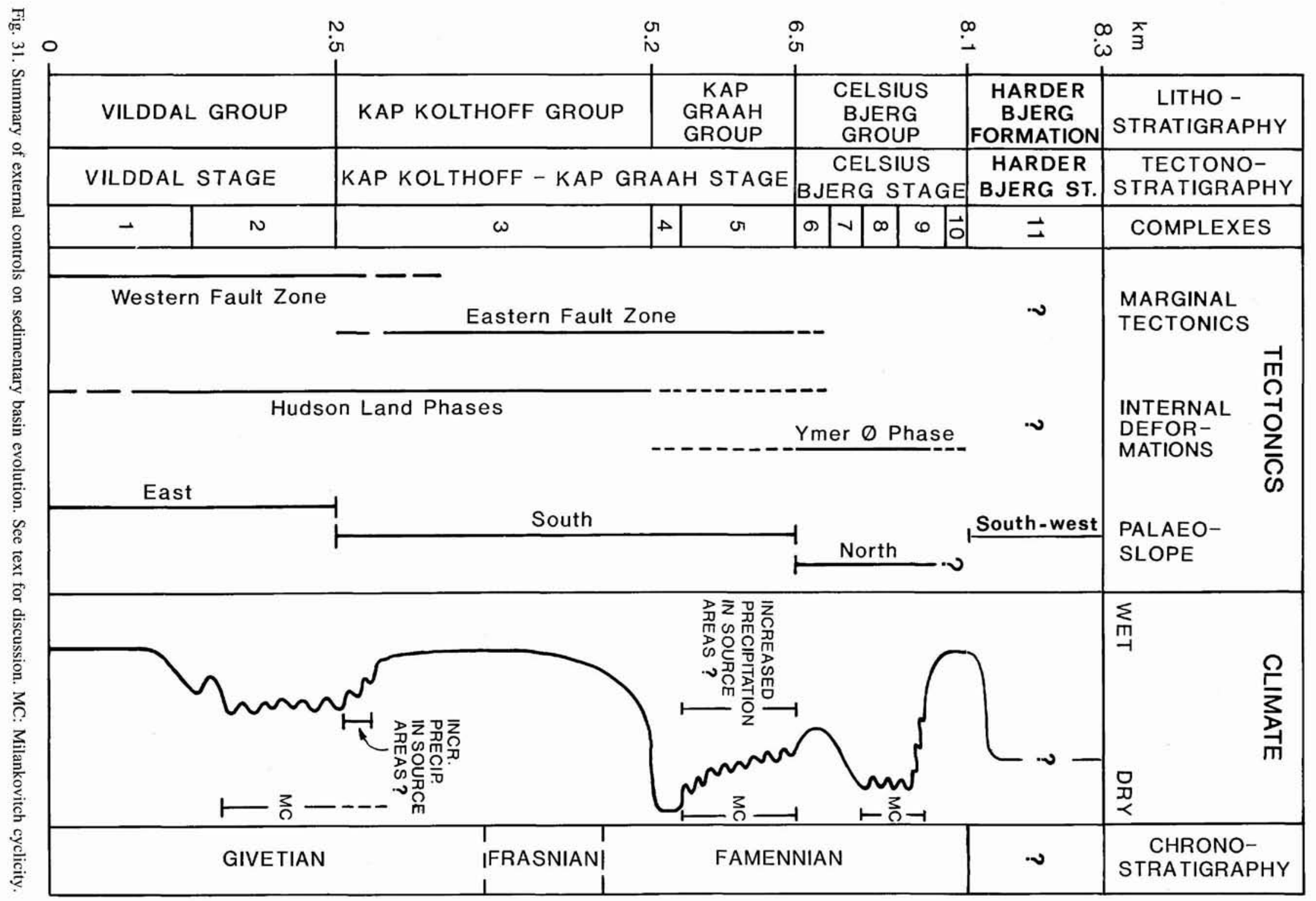


fault zones were caused by sinistral strike slip, as also suggested by Larsen \& Olsen (1991). In general, the palaeogeography of Friend et al.'s (1983) Kap Kolthoff Supergroup corresponds with the palaeography depicted here for the Kap Kolthoff Group (complex 3). However, one major difference is their identification of the conglomerates along the Western Fault Zone as part of their Kap Kolthoff Supergroup. They suggest that these conglomerates reflect the existence of large alluvial fans in the initial stage of the Gauss Basin. In the present paper these conglomerates form the proximal part of a gravelly braid plain depositional complex 1 in the Vilddal basin stage. In support of this interpretation is the recognition of channellized streams as the dominant sedimentary elements. In contrast alluvial fans tend to be dominated by sheetfloods with incised channel deposits as minor constituents (Blair, 1987a).

The Gauss Basin of Friend et al. (1983) also includes their Kap Graah Group and Mount Celsius Supergroup. They suggested that local tectonic tilting and erosional truncation preceded deposition of the Kap Graah Group. They placed, however, the base of the Kap Graah Group at an angular unconformity within the Kap Kolthoff Group, as defined by Olsen \& Larsen (1993a).

Friend et al. (1983) did not recognize a major climatic shift at the lower boundary of complex 4 (base of the Kap Graah Group), mainly because they interpreted aeolian deposits as fluvial at a number of localities. In particular successions with aeolian sand-sheet deposits and aeolian dune deposits characterized by relatively small cross-sets formed the basis of the misinterpretation.

The 'upper Kap Graah Group' and the Mount Celsius Supergroup of Friend et al. (1983) correspond to the Celsius Bjerg Group, as defined by Olsen \& Larsen (1993a). Friend et al. (1983) interpreted the general palaeogeography as a longitudinally drained basin with rivers flowing mainly in a northward direction which is in accordance with the general picture depicted herein for the Celsius Bjerg basin stage.

According to Friend et al. (1983) the final episode in the area was the termination of Devonian deposition due to the compressional deformation of the Ymer phase (cf. Bütler, 1935a), supposedly of Early Carboniferous age. However, as already stated, the Ymer $\emptyset$ phase apparently started in the Late Devonian and the initiation should be arbitrarily placed in the Kap Kolthoff - Kap Graah basin stage.

\section{Summary of the basin evolution}

The basin evolution has, as shown in previous sections, been strongly controlled by an interplay of tectonic and climatic events. The main events and controlling factors are summarized below and in Fig. 31 .

The initiation of the Vilddal basin stage was controlled by an extensional collapse and the establishment of the Western Fault Zone with sinistral strike-slip. During the Vilddal basin stage marginal faulting and internal deformation of the basin fill occurred, related to the Hudson Land phases of Bütler (1935a, 1959). The palaeoslope was towards the east.

The establishment of the Eastern Fault Zone and slowing down of activity along the Western Fault Zone characterized the onset of the Kap Kolthoff - Kap Graah basin stage. The Eastern Fault Zone was probably also a sinistral strike-slip or oblique-slip fault zone (Larsen \& Olsen, 1991). The Hudson Land deformation phases resulted in several internal unconformities, mainly along the Eastern Fault Zone, during deposition of complex 3 (Larsen, 1990d). The palaeoslope was southwards and sediment input was from both east and west. A gradual improvement in climate is observed in early complex 3 time. Depositional complex 4 reflects a rapid aridification to desert conditions with development of a basin-wide erg. Relatively dry climatic conditions also persisted during deposition of complex 5 . The source terrain along the Eastern Fault Zone was uplifted during deposition of complex 5 and tectonic movements apparently also occurred north of the basin. The tectonism caused the eastern transverse alluvial system to expand and also resulted in the establishment of an axial river system with headwaters in the north. The Ymer $\varnothing$ deformation phase (Bütler, 1935a) gradually replaced the Hudson Land phases and resulted in synsedimentary open folds locally associated with thrusts or normal faults (Larsen, 1990d; Olsen \& Larsen, 1993b). The axial drainage was southwards, but the axis was structurally forced towards the west during deposition of the complex.

The Celsius Bjerg basin stage is characterized by a northward palaeoslope. This change from the underlying Kap Kolthoff - Kap Graah basin stage was also associated with a transgression of the Eastern Fault Zone which apparently exhibited limited activity during deposition of the basin fill (P.-L. Larsen, personal communication, 1990). The Ymer $\emptyset$ deformation phase, however, continued throughout this basin stage and greatly influenced the valley slope and position of depocentres. The climate changed gradually to more humid conditions and finally, due to tectonic movements, a closed basin was established and a basin-wide permanent lake developed.

The final episode in the Devonian basin evolution seems to be the development of the Harder Bjerg basin stage exhibiting southwestward drainage. Tectonism is interpreted as controlling the development of this new drainage direction. Further investigations are, however, 
needed to outline the depositional history of this stage and its controlling factors.

The Devonian basin in North-East Greenland accordingly underwent five major events of basin-scale influence. Firstly the initiation of the Vilddal basin stage and establishment of the Western Fault Zone; secondly the establishment of the Eastern Fault Zone and the Kap Kolthoff - Kap Graah basin stage; thirdly the aridification halfway through the Kap Kolthoff - Kap Graah basin stage; fourthly the establishment of the Celsius Bjerg basin stage associated with an inversion of palaeoslope; and finally the change in palaeoslope towards the southwest in connection with the transition to the Harder Bjerg basin stage. No signs of the termination of the basin are preserved.

\section{Regional tectonic and climatic framework Tectonics}

A reconstruction of the Laurasia or Old Red continent indicates that the basin boundary faults, i.e. the Eastern and Western Fault Zones in North-East Greenland could represent the northward continuation of the Great Glen fault in Scotland and the Walls boundary fault in the Shetland Islands (Larsen \& Bengaard, 1991). This is termed the Arctic - North Atlantic Fault (ANAF) zone in the palaeogeographic reconstruction (Fig. 32) in accordance with Ziegler (1988). The zone shows combined post-Caledonian extensional and sinistral wrench tectonics and in this way exhibits close affinity to the Devonian basin in Greenland.

After the Caledonian E-W compressional stresses decreased in the Middle Devonian, an overthickened crustal welt including East and North-East Greenland may have resulted in extensional collapse (McClay et al., 1986; Norton et al., 1987; Séguret et al., 1989; Larsen \& Bengaard, 1991).

A series of small, late Caledonian (largely LowerMiddle Devonian) basins are present along coastal Norway between Bergen and Trondheim (e.g. Nielsen, 1973; Steel, 1976). Steel (1976) and Steel \& Gloppen (1980) amongst others, argued that some of these basins originated as strike-slip basins. However, reappraisal of these basins (Hossack, 1984; McClay et al., 1987) demonstrated that extensional tectonics dominate, and that the east-west directed margin faults are most likely to be lateral ramps and link/transfer faults in a large extensional fault system. The westward drainage pattern of these basins combined with the eastward drainage in the Vilddal basin stage in Greenland suggest convergence in the axial zone of the former Caledonian crustal welt. This zone, accordingly, may have been the locus of maximum extension related to the basin initiation in both Greenland and Norway, and probably coincides with the Arctic North Atlantic Fault zone.

Sinistral lateral motions of the Laurential plate (with Greenland) and the Baltic plate along the Arctic - North Atlantic Fault zone accompanied the extensional tectonics and subsequently dominated the basin and resulted in the establishment of the strike-slip or oblique-slip Eastern Fault zone and development of the Kap Kolthoff - Kap Graah basin stage. The reversal of palaeoslope recorded in the Celsius Bjerg basin stage is also consistent with an oblique-slip basin model, involving oblique convergence of plates. Lawrence \& Williams (1987) and Lawrence \& Rust (1988) report a similar axial drainage reversal in the southern part of the Arctic - North Atlantic Fault Zone in the Gaspé Peninsula in Canada, and explain this by oblique collision between the irregular margin of North America and an exotic terrain, comparing closely to the supposed mechanism in North-East and East Greenland.

\section{Climate}

The North-East Greenland Basin was situated at $c$. $5^{\circ}-10^{\circ} \mathrm{N}$ latitude during the Middle to Late Devonian and formed part of the equatorial Laurasia continent (Smith $e t$ al., 1981; Van der Voo, 1988; Ziegler, 1988). It was probably located in a trade wind belt, though experiencing a monsoonal climate in the summer (Olsen, 1990). The palaeowind pattern may be explained by the low latitude position of the basin. The general palaeowind directions measured in the Devonian succession are towards southwesterly directions and towards NE, conforming with the trade wind pattern north of equator and monsoonal summer winds, respectively (Fig. 32 ). In the Barnabas Dal Formation the western basin margin fault probably affected northeasterly directed monsoonal winds in a manner similar to dune lee faces, as described by Sweet \& Kocurek (1990). The oblique flow, with respect to the fault scarp orientation, resulted in deflection of air flow along the fault scarp and thus northerly directed monsoonal winds. An inferred subordinate (trade) wind was directed southwestwards (Fig. 37; see next chapter).

It has been suggested that variations in the earth's orbit, the so-called Milankovitch cyclicity, cause cyclic changes in the geographical and seasonal distribution of solar radiation resulting in climatic cyclicity (e.g. Hays et al., 1976, Berger, 1977). Increased seasonal variation in solar radiation would result in a higher temperature gradient between the ocean and the continent. The increased temperature gradient would cause a northward progradation of the Inter-Tropical Convergence zone (ITC) during summer in the northern hemisphere (Fig. 32) and thus an 

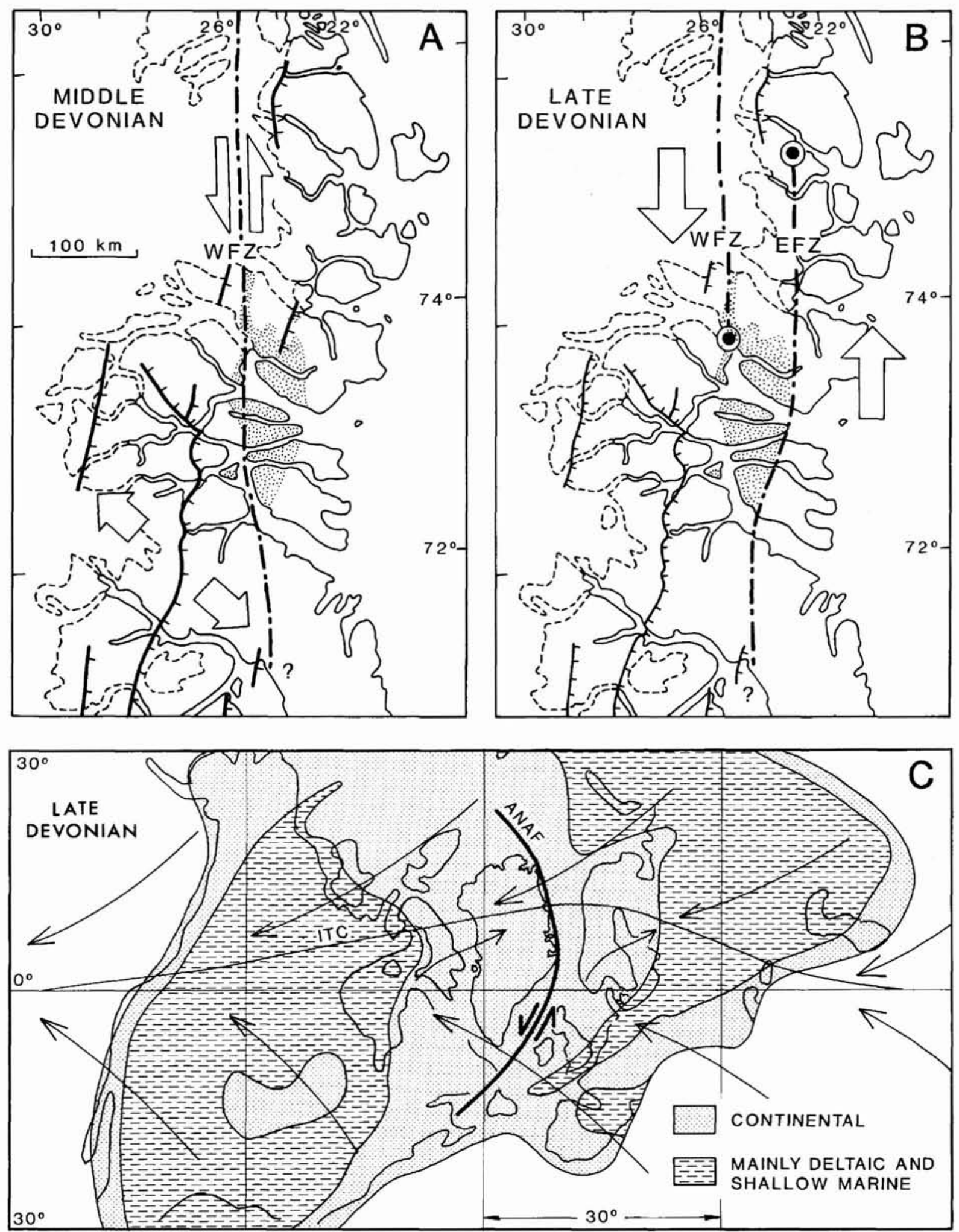

Fig. 32. Regional tectonic and climatic framework of the North-East and East Greenland basin. (A) and (B) show the tectonic setting of the basin in Middle and Late Devonian. WFZ: Western Fault Zone; EFZ: Eastern Fault Zone. After Larsen \& Olsen (1991). (C) is a reconstruction of the Laurasia continent in the Late Devonian. The tectonic active Arctic - North Atlantic Fault zone (ANAF) goes through North-East and East Greenland. Summer time position of the Inter-Tropical Convergence zone (ITC) is shown. SW-directed trade winds are observed north of ITC. South of ITC, NE-directed monsoonal winds are observed, and further south, NW-directed trade winds occur. Continental position is based on Smith et al. (1981); palaeogeography and ANAF are based on Ziegler (1988). 
intensified monsoonal circulation and an increased summer precipitation (e.g. Kutzbach \& Street-Parrott, 1985).

When the ITC summer position was close to the Devonian basin in North-East Greenland, the local climate was probably very sensitive to the Milankovitch cyclicity, and a cyclic pattern would be reflected in the deposits as seen in the Andersson Land and Wimans Bjerg Formations, and probably also the Ankerbjergselv and Britta Dal Formations. However, when the ITC was continuously north or south of the basin during the summer, the climate would be comparably stable.

The extremely arid climate during deposition of complex 4 in the Kap Kolthoff - Kap Graah basin stage could correspond to a period when the ITC was continuously situated south of the basin, prohibiting humid monsoonal winds in reaching the basin. Such a situation would occur when the orbit of the earth was extremely elliptical for a prolonged period. However, relatively arid conditions were also maintained during deposition of complex 5 and the main part of the Celsius Bjerg basin stage, and thus involving the main part of the Famennian (Fig. 31). This implies a duration of dry climate in the order of $10^{6}$ years, much longer than involved in the Milankovitch cycle theory (e.g. Berger et al., 1989). Moreover, Milankovitch cyclicity is very well developed in the upper Kap Graah Group and lower Celsius Bjerg Group, indicating a summer time position of the ITC close to the basin and not constantly south of the basin. Accordingly the aridity must have been caused by some other factor.

During the Frasnian the global sea-level rose, reaching a high-stand at the Frasnian-Famennian boundary (Johnson et al., 1985). During the Famennian a major regression occurred, coinciding with the development of extensive inland ice-sheets in Gondwana (Caputo \& Crowell, 1985). The combined effect of glaciation and regression was a cooling of the ocean temperature and a longer distance from the ocean to the Devonian basin in Greenland. A cooler ocean probably would result in decreased evaporation and thus drier air, blowing from the ocean towards the continent. Moreover, the increased distance from the ocean to the basin could result in increased loss of water due to precipitation in other parts of the continent, prior to reaching the basin in Greenland. Accordingly the aridification in the upper Kap Kolthoff - Kap Graah and lower-middle Celsius Bjerg basin stages may be explained by the glacially induced Famennian regression. 


\section{Facies associations}

In this chapter a detailed documentation of facies associations in the Devonian basin is presented and compared with the sedimentological investigations carried out by the Cambridge group in the late sixties to early eighties (cf. Friend, 1983). They used a system of so-called 'sample groups' to describe the deposits, based on a computerized section description system (Friend et al., 1976a). The sample groups are not traditional facies associations, i.e. all measured sections were subdivided into ten metre intervals, and each ten metre interval was allotted by computer to a sample group according to the sedimentary characteristics of that particular interval. This was done irrespective of the possible presence of several traditional facies associations within a ten metre interval.

\section{Aeolian dune association General characteristics}

The aeolian dune association (Figs 33-37) is composed of well-sorted fine to coarse-grained, trough crossbedded sandstones. The aeolian dune nature of this facies association is indicated by the assemblage of inclined sand flow, climbing translatent, and grainfall strata. The sediments were deposited as 3-D dunes indicated by the trough-shape of individual cross-sets.
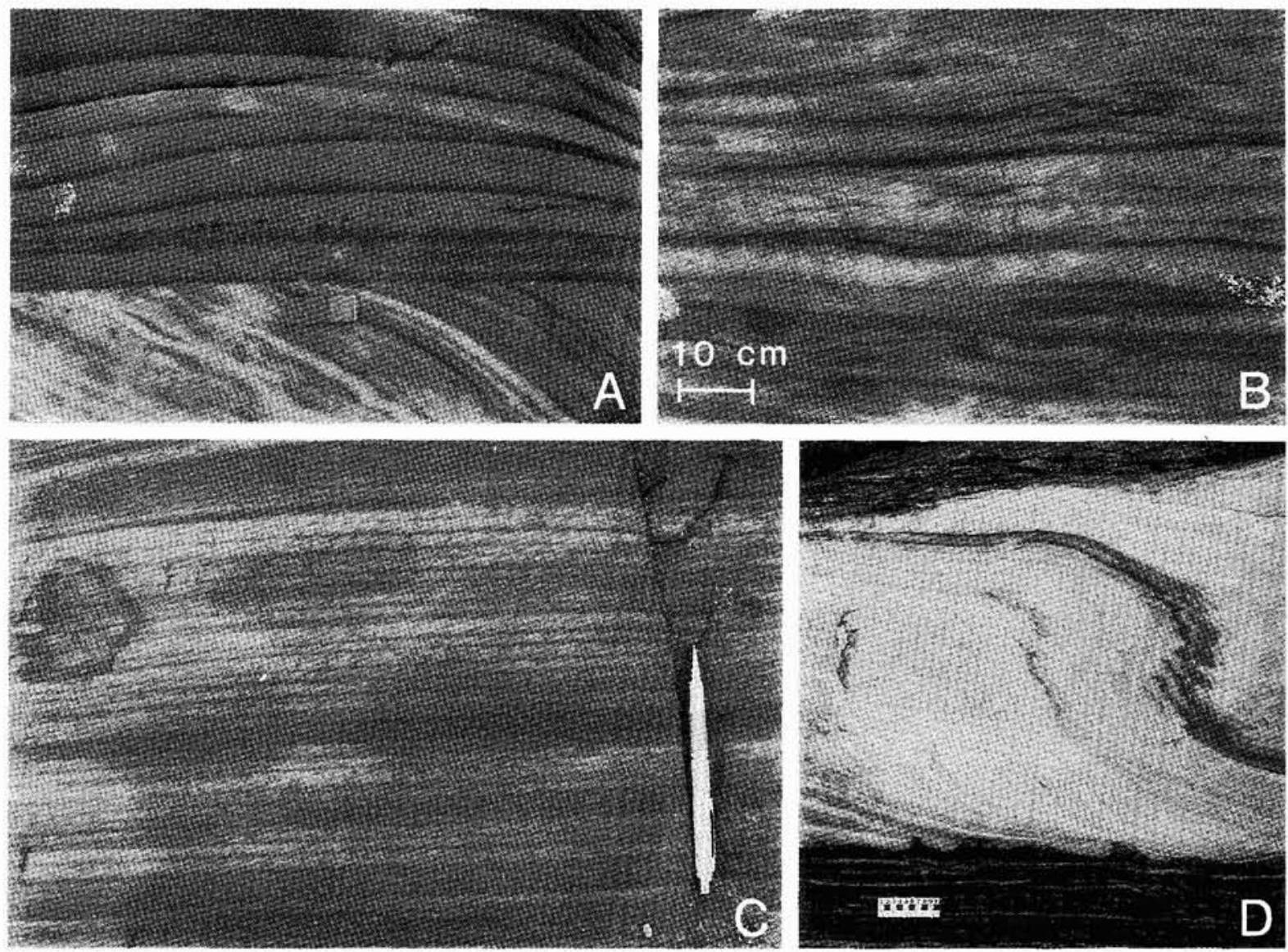

Fig. 33. Stratification types in sandstones of the aeolian dune association. (A) Well defined coarsening upward sandflow strata in transverse cross-section (above $5 \mathrm{~cm}$ long eraser). Notice the lenticular shape. (B) Laterally amalgamated sandflow strata with indistinct boundaries of individual strata. Transverse cross-section. (C) Climbing translatent strata with well defined coarsening upwards of individual strata formed by climbing wind ripples. Length of pencil is $14 \mathrm{~cm}$. (D) Penecontemporaneous deformation of cross-stratification. Overturned folds and normal faults are observed. At the base of the cross-set loading into irregular laminated interdune deposits is also observed. Measure is $10 \mathrm{~cm}$ long. All photographs are from the Barnabas Dal Formation at Rødebjerg. 

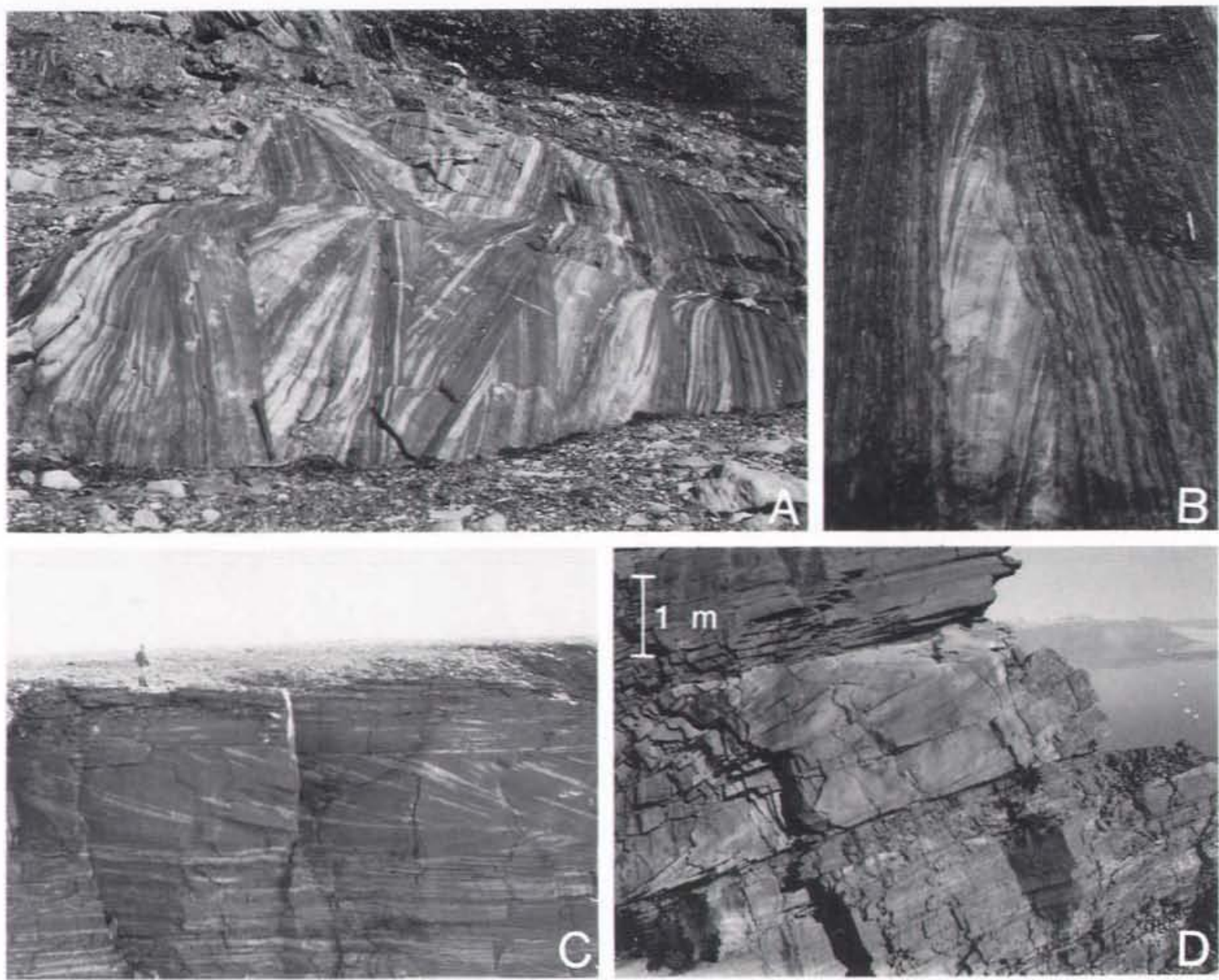

Fig. 34. Cross-bedding in the aeolian dune association. (A) A coset of trough cross-bedded sandstones (Barnabas Dal Formation at Rødebjerg). Tectonic dip is almost $90^{\circ}$ to the left. The coset was deposited by a large compound dune. A $30 \mathrm{~cm}$ long hammer is used for scale. (B) Thin solitary cross-set embedded in sand sheet/interdune sandstones (Barnabas Dal Formation at Rødebjerg). Notice the differential erosion in top of the cross-set. The cross-set was deposited as a small barchan in the interdune area. Up is to the right. Pencil is $14 \mathrm{~cm}$ long. (C) A large simple cross-set, apparently tabular, embedded in aeolian sand sheet deposits (Woodward Bjerg Formation at Rødtop). Man for scale in the upper left. (D) A tabular coset in which the individual cross-sets appear tabular (Udkiggen Formation at Rødsten). In transverse cross-section the coset is similar to (A). The coset is likewise interpreted as a compound dune.

\section{Previous investigations}

Aeolian dune deposits were identified and described as part of sample groups $2 \mathrm{E}$ and $2 \mathrm{C}$ by Nicholson \& Friend (1976) and sample groups IC and $2 \mathrm{~F}$ by Yeats \& Friend (1978). The fieldwork of these investigators was, however, carried out before the pioneer paper on aeolian stratification types by Hunter (1977), and dune deposits were recognized on the basis of large (metre-scale) set sizes, absence of pebbles and of channel-scours, and palaeocurrents deviating from the general fluvial palaeocurrent direction (Friend et al., 1983). Thin dune deposits associated with sand sheet, interdune and fluvial deposits were thus not recognized as aeolian in origin. Therefore it was suspected and also confirmed in the field by the present author that aeolian dune deposits are present in the majority of red sandstone sample groups of Alexander-Marrack \& Friend (1976); Nicholson \& Friend (1976), Yeats \& Friend (1978) and Friend et al. (1983).

\section{Details}

The sandstones are generally red or variegated, with dark red finer-grained strata and light red or reddish grey coarser-grained strata (Figs 33, 34A, B, C). Cross-sets range in thickness from $c .10 \mathrm{~cm}$ to $20 \mathrm{~m}$ and from $3 \mathrm{~m}$ to 

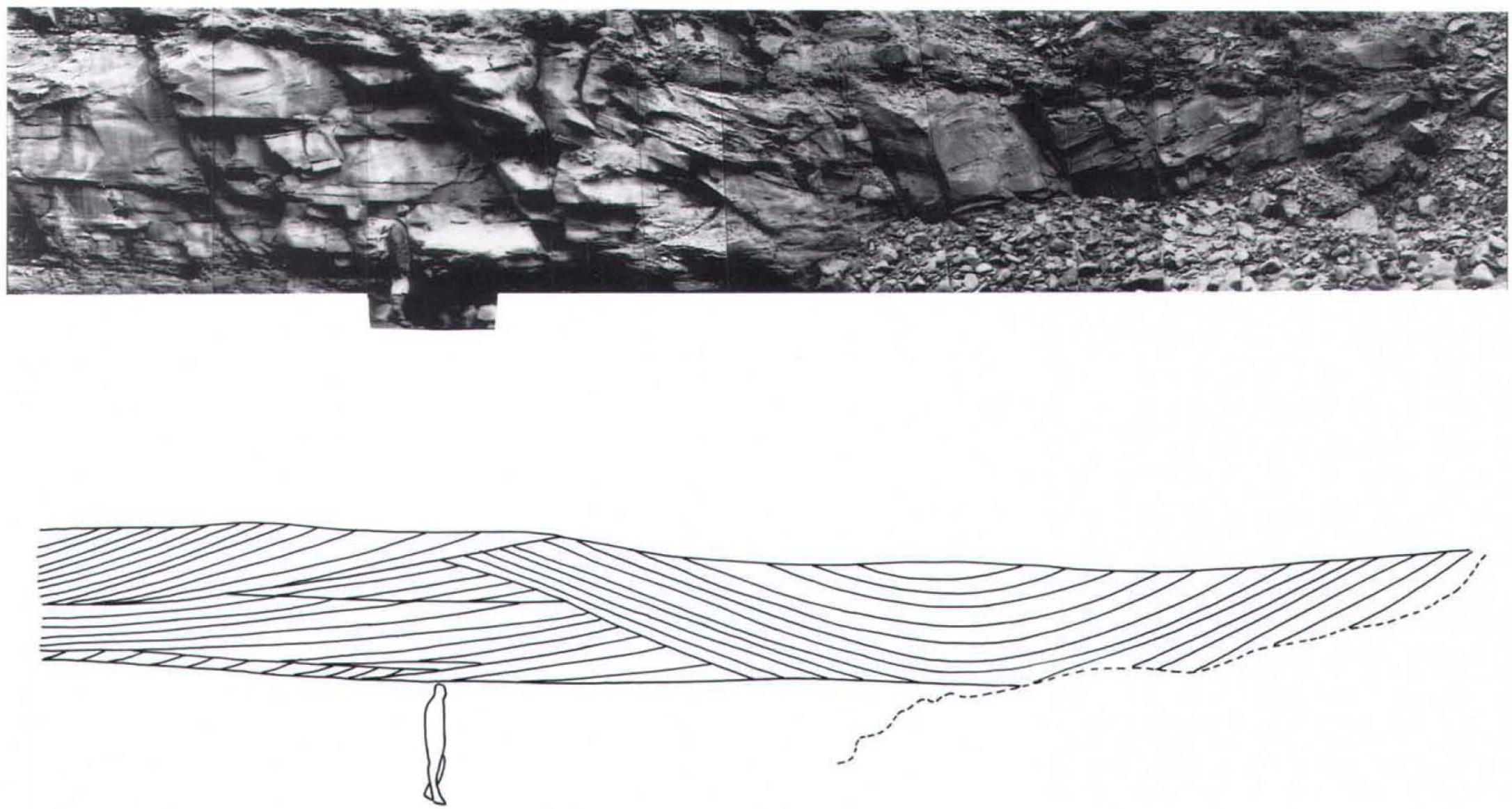

Fig. 35. Aeolian dune association. A multi-lateral coset: a large simple cross-set closely associated with a cross-bedded coset of equal thickness (Langbjerg Formation in Moskusokselandet). Notice the zig-zag structure obliquely above the head of the person, indicating the existence of a lee-side spur. The bed was deposited by a compound dune with a simple slip face (right) and a lee-side with smaller descending dunes (left). Wind was towards the viewer. Notice the flat base of the trough-shaped simple set. 
Fig. 36. Aeolian dune association. Two tabular dune units are observed, separated by thin interdune deposits. The upper dune unit is composed of a simple cross-set. The lower unit is composed of a coset that is replaced down-wind (left) by a simple cross-set. Direction of large dune migration is obliquely to the left almost parallel to the exposure. Notice that the small dunes, i.e. trough sets in the coset, migrated perpendicular (into the exposure) to the large dune migration. (Udkiggen Formation at Kap Graah.)

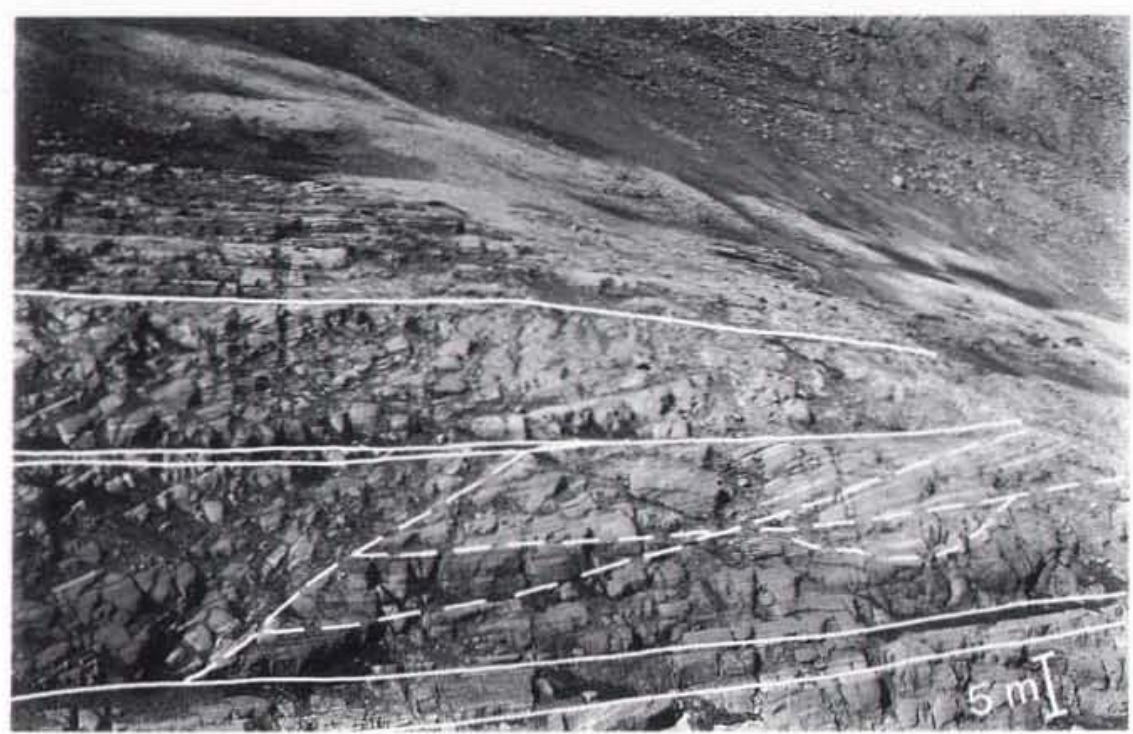

$60 \mathrm{~m}$ in width (transverse to inferred dune-migration direction). Set length commonly exceeds $50 \mathrm{~m}$ and length/thickness ratio is rarely less than 20 . The sets are trough-shaped with curved (concave-up) lower bounding surfaces exposed in transverse and oblique cross-sections and apparent planar lower bounding surfaces exposed in longitudinal cross-sections (Fig. 34C). Cross-bedding occurs both as simple sets (in a vertical sense) and as cosets. The cross-strata are tangential to concave with maximum dips in excess of 25 degrees. The cross-strata are composed of sandflow and climbing translatent strata and rare grainfall strata (cf. Hunter, 1977). Irregular adhesion lamination and medium to coarse-grained wind ripple forms also rarely occur in the lowermost part of the sets.

The sandflow strata are generally coarser-grained and lighter coloured than the climbing translatent and grainfall strata. The dominant grain size is medium-grained sand. In transverse section sandflow strata are lenticular, $0.5-25 \mathrm{~cm}$ thick (usually $<10 \mathrm{~cm}$ ) and $20-200 \mathrm{~cm}$ wide (Fig. 33A), and commonly several flows may amalgamate laterally with indistinct boundaries between individual units (Fig. 33B). In longitudinal section strata are wedge-shaped, thinning down-dip. They are internally massive, usually nongraded, but inverse grading is common (Fig. 33A) while normal grading is rare.

Translatent strata are composed of fine-grained to medium-grained sand, dominated by the fine-grained sand fraction. Individual strata are usually $1-3 \mathrm{~mm}$ thick but may be up to $10 \mathrm{~mm}$. Ripple-foreset cross-lamination occasionally occurs in thicker translatent strata. Individual strata are extensive despite the thinness, and may be traced for several metres. Inverse grading is typical (Fig. $33 \mathrm{C}$ ). but may, however, be difficult to perceive in the thinner strata, where only local pin stripe lamination may be seen (cf. Fryberger \& Schenk, 1988). Grainfall strata are rare. They resemble the translatent strata except that grading and pin stripe lamination are generally absent.

Penecontemporaneous deformation is locally abundant (Fig. 33D), including drag folds, overturned folds, overthrusts, normal faults, break-apart laminae and rotated blocks. The latter four types of deformation indicate ephemeral wetting of the dune surfaces (McKee et al., 1971). Loading structures occur locally at the base of cross-sets overlying irregular laminated interdune sandstones (Fig. 33D).

Sets, less than $1 \mathrm{~m}$ thick commonly occur as solitary sets and as multi-lateral cross-beds, composed of laterally linked simple sets, embedded in and laterally grading into sandstones of the sand sheet/interdune association (Fig. 34B).

The thin solitary sets and multi-lateral cross-beds were deposited as small isolated lunate bedforms (barchans) and small sinuous crested to lunate (barchanoid) dunes, respectively (e.g. Glennie, 1970, Rubin, 1987). The close association with and lateral transition into the sand sheet/ interdune deposits indicate an origin in a low relief aeolian sand sheet environment, and in the flat interdune areas between larger dunes. The scarcity of cosets in these deposits indicates large spacing between individual dunes in the sand sheet/interdune settings.

Tabular sandstone bodies, 2-20 m thick, composed of multi-lateral simple cross-sets (Fig. 34C) and cosets (Figs $34 \mathrm{~A}, \mathrm{D})$ are common in the facies association. In flowtransverse cross-sections these sandstone bodies usually prove to be multi-lateral cosets, composed of both cosets and equally thick simple sets (Fig. 35). A typical feature of the sandstone bodies is a planar base without troughshaped depressions when seen in transverse cross-sec- 
A

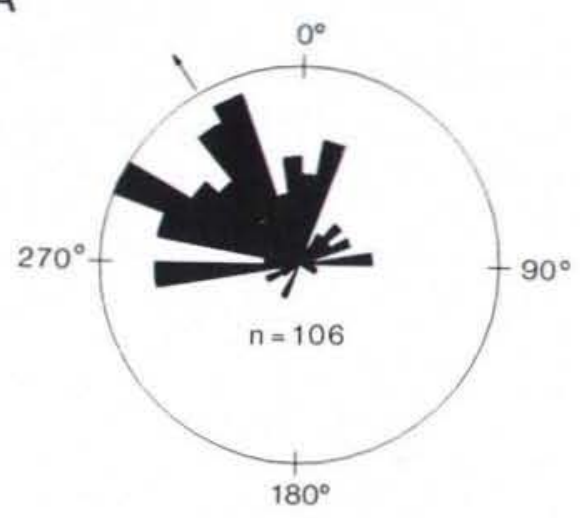

B

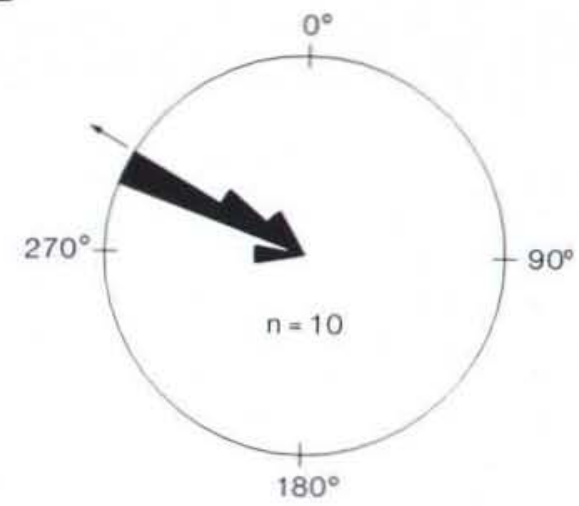

C

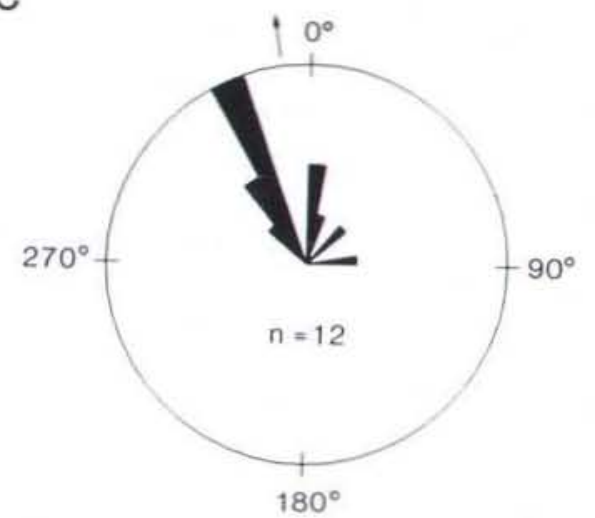

D

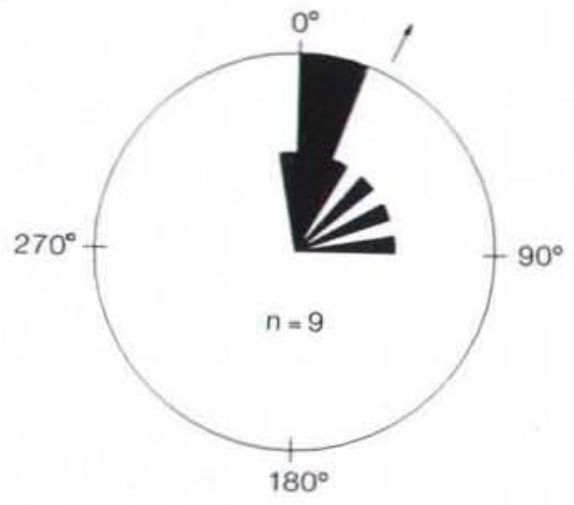

$E$

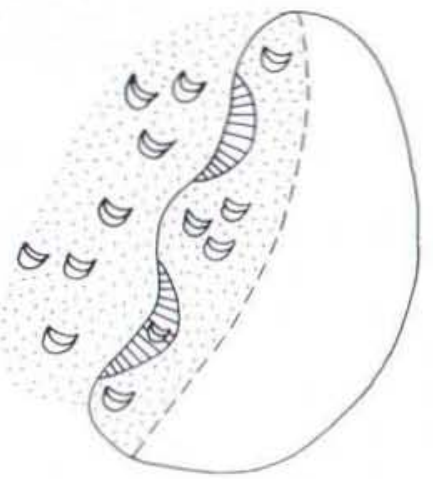

$\mathrm{F}$

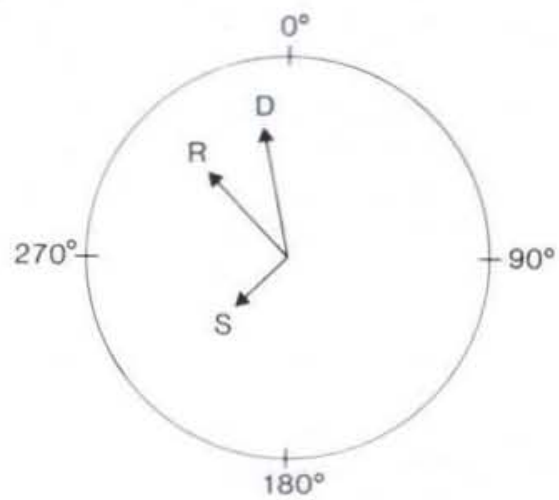

Fig. 37. Palaeowind roses (linear plots) and reconstruction of dune morphology and wind regime from aeolian dune deposits in the Barnabas Dal Formation at Rødebjerg. (A) Total number of measurements. (B) Measurements from large simple cross-sets, forming part of multi-lateral cosets. (C) Measurements from cosets, forming part of multi-lateral cosets. (D) Measurements from cross-sets associated with interdune deposits. (E) Reconstruction of large compound dune with local development of slip face. Notice the superimposed dunes, migrating along the lee-slope of the larger dune. Small dunes in the interdune corridors also migrate at right angles to the large dune. (F) Inferred wind regime for the Barnabas Dal system at Rødebjerg. D is dominant wind. $\mathrm{S}$ is subordinate wind, $\mathrm{R}$ is resultant wind direction. 
tions (Fig. 35). Bounding surface traces between adjacent simple sets or cosets occasionally exhibit zig-zag structures, resembling herringbone bedding (Fig. 35).

The thick multi-lateral cosets of laterally linked cosets and large simple sets were deposited as compound dunes. The compound dunes were sinuous crested (cf. Rubin, 1987) locally associated with large concave down-wind slip faces (simple sets). The dunes were, however, dominated by gentler sloping leesides with superimposed smaller 3-D dunes (cosets). The planar bases of multilateral cosets indicate that despite having a three-dimensional lee slope, the compound dunes must have had troughs that did not vary in along-slope elevation, i.e. scour pits were lacking probably due to moderate planform sinuosities (Rubin, 1987). The dunes were occasionally associated with lee-side spurs, as evidenced by the zig-zag structures (Rubin \& Hunter, 1983; Rubin, 1987),

In rare 3-D exposures of cosets it was observed that trough axes orientation of the constituent small sets are roughly perpendicular to the dip direction of secondorder bounding-surfaces (cf. Brookfield, 1977; Fig. 36). Systematic measurements of second-order bounding surface orientations were not carried out, but in well-exposed outcrops second-order surfaces were observed to dip at a low angle $\left(<15^{\circ}\right)$ almost in the same direction as the cross-strata of associated large simple sets (Fig. 36). Plots of cross-bed dip directions measured in dune-dominated successions may exhibit apparently unimodal distributions at individual localities, although with considerable dispersion (Fig. 37A). However, if cross-bed dips are measured separately from large simple sets, laterally equivalent cosets, and small sets associated with interdune deposits, three separate classes of dip directions may be observed as seen in the Barnabas Dal Formation (Fig. 37). Large simple sets and cross-sets associated with interdune deposits exhibit dips at right angles (Fig. 37B,C), whereas cross-beds from thick cosets dip in a direction intermediate between the two others (Fig. 37D).

The apparently unimodal foreset dips suggest a transverse dune origin (e.g. Kocurek, 1981a; Blakey \& Middleton, 1983; Kocurek \& Dott, 1983; Clemmensen \& Abrahamsen, 1983; Hubert \& Mertz, 1983; Ross, 1983; Loope, 1984). The geometrical relationship between the large simple cross-sets, second-order bounding surfaces in co-sets and trough axes of constituent sets indicates, however, that the compound cross-bedding (cosets) was formed by large bedforms with along-slope-migrating superimposed smaller bedforms (compare with Rubin, 1987, figs $46 \mathrm{M}, 46 \mathrm{~N})$. The low-angle dips of secondorder surfaces dipping almost in the same direction as simple cross-strata are probably a combination of gently sloping leesides and high ratio of migration speed of superimposed dunes relative to the large dunes (cf. Rubin. 1987). The tri-partite distribution of cross-stratal dip directions from simple sets, cosets and interdune-related cross-sets may similarly be explained by smaller bedforms superimposed on and situated in interdune areas between larger dunes, and migrating parallel to the crestlines of the larger dunes. Such conditions are achieved when the wind direction is oblique to the crestline orientation of the larger dunes, resulting in deflection of lee airflow and parts of interdune airflow parallel to the large dune crestlines (Sweet \& Kocurek, 1990). The large dunes accordingly were either oblique sensu stricto (Hunter et al., 1983; Rubin \& Hunter, 1985) or transverse with respect to the annual resultant transport direction but oblique relative to the dominant seasonal wind (Sweet $e t$ al., 1988: Havholm \& Kocurek, 1988).

When independent palaeowind directions are obtained from small dune cross-beds associated with aeolian sandsheet deposits sensu stricto, vector means close to the dip directions of large simple sets are observed. According to Clemmensen \& Blakey (1989) vector means from such small dunes far from the larger dunes provide good estimates of the annual resultant transport direction. Accordingly the large compound dunes were probably transverse relative to the resultant transport direction but oblique in respect to a dominant seasonal wind. The former controlled the orientation of the large dunes, whereas the deflection of lee airflow during dominant seasonal winds was responsible for along-slope-migration of smaller superimposed dunes.

\section{Aeolian sand sheet/interdune association General characteristics}

The deposits of this association are generally red or variegated sandstones which exhibit a variety of sedimentary structures and stratification types, commonly intricately interbedded (Figs 38-40). The sediments comprise: (1) low-angle or horizontally laminated, mainly fine-grained translatent strata (abundant); (2) wind ripple formsets of medium to coarse-grained sand (common); (3) irregular lamination of various grain sizes (rare to common); (4) differential erosion (rare to common); (5) rootlets and burrows (rare to common); (6) desiccation cracks in mud (rare to common); (7) symmetrical ripple formsets in fine-grained sand (rare). The sedimentary structures and textures clearly indicates that the association is mainly aeolian, dominated by wind ripple deposition. 

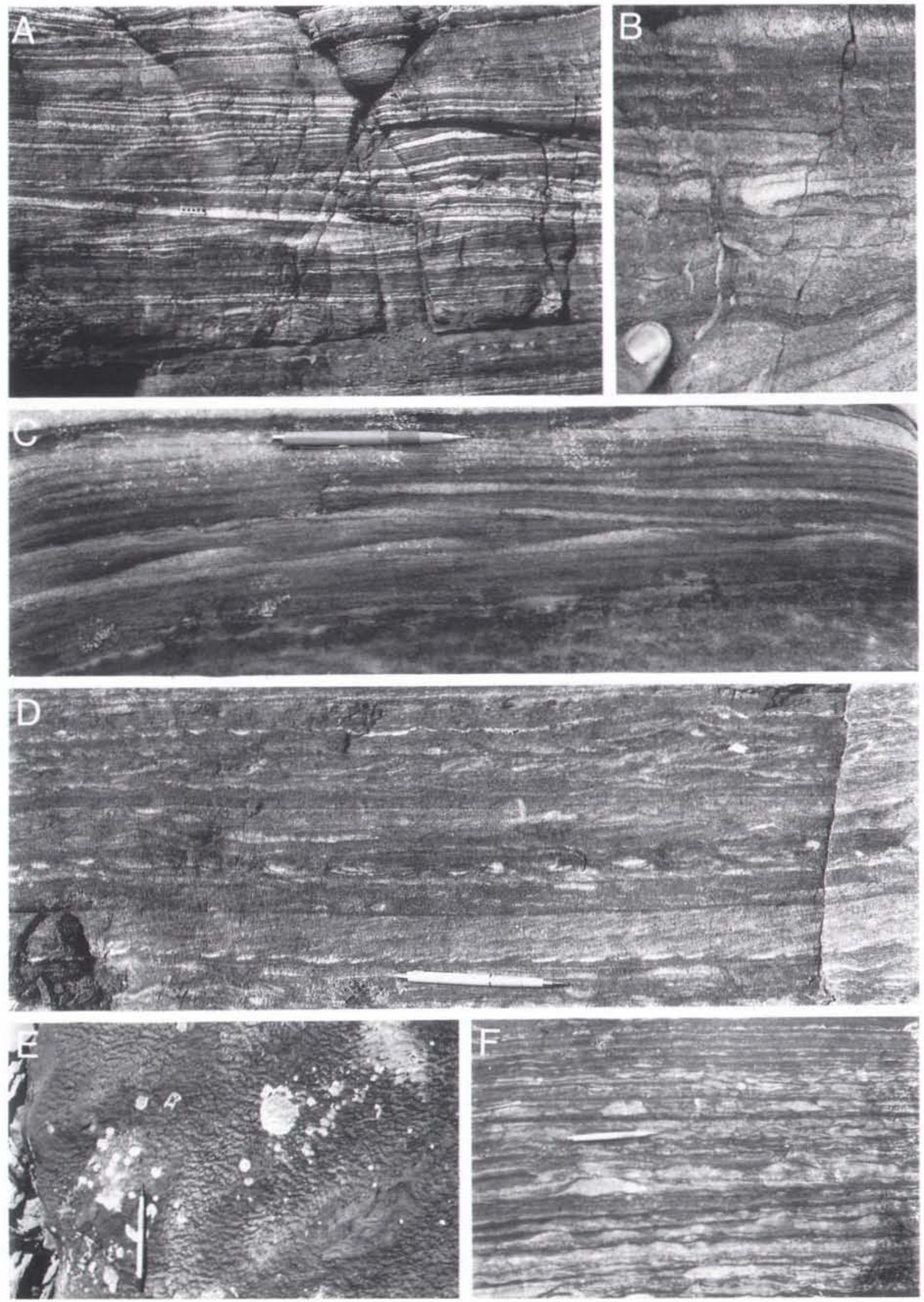


\section{Previous investigations}

Aeolian sand sheet and interdune deposits have not been identified previously within the Devonian succession of North-East Greenland. The present investigation shows, however, that these deposits form part of a number of the red sandstone sample groups of Friend et al. (1983) and were interpreted to be fluvial in origin.

\section{Details}

The association is dominated by horizontal to lowangle $\left(<15^{\circ}\right)$ parallel lamination of translatent strata in fine-grained sandstone occurring in decimetre thick sets (Fig. 38A). The sets of parallel lamination are bounded by erosional and non-erosional surfaces and rarely exceed $10 \mathrm{~m}$ in lateral extent. The translatent strata are similar in character as described for the aeolian dune association. However, in contrast to the dune association translatent strata in this association are closely associated with medium to coarse-grained wind ripple formsets. The formsets are asymmetric and possess a high length/height ratio with length in the range of $5-20 \mathrm{~cm}$ and height between 2 $\mathrm{mm}$ and $10 \mathrm{~mm}$ (rarely up to $30 \mathrm{~mm}$ ). The formsets are almost always inversely graded and usually occur as ripple trains (Fig. 38C).

The low-angle and horizontally laminated translatent stratification associated with wind ripple formsets represent deposition by wind ripples in relatively dry, lowrelief aeolian sand sheets (Fryberger et al., 1979, 1983: Kocurek \& Nielson, 1986) and interdunes (Ahlbrandt \& Fryberger, 1981; Kocurek, 1981b; Lancaster \& Teller. 1988). The typical low-angle development of translatent strata in sets commonly separated by erosion surfaces indicates repeated erosion and deposition of low sand mounds without slip faces (Kocurek \& Nielson, 1986). The presence of rootlets in the sediments may indicate a shadow dune or sand shadow origin of some of these

Fig. 38. Aeolian sand sheet/interdune association. (A) Lowangle laminated climbing translatent strata (Rødebjerg Formation at Rødebjerg). Ten $\mathrm{cm}$ bar for scale. (B) Calcified rootlets associated with irregular lamination (Rødebjerg Formation at Rødebjerg). Finger tip in lower left for scale. (C) Wind ripple formsets of medium-grained sand associated with translatent strata and fuzzy irregular lamination (Barnabas Dal Formation at Rødebjerg). The ripples migrated towards the right. (D) Fuzzy irregular lamination, inclined and horizontal, formed by adhesion ripples (Barnabas Dal Formation at Rødebjerg). (E) Adhesion ripples on a bedding plane (Ankerbjergselv Formation at Ankerbjergselv). Wind direction is up. (F) Intricate irregular pattern with truncated symmetrical ripple forms and fuzzy horizontal lamination (Barnabas Dal Formation at Rødebjerg). Length of pencil in C.F is $14 \mathrm{~cm}$. dipping strata, although the typical zig-zag structure of low-angle laminated sets was not observed (cf. Clemmensen, 1986). Distinct coarser grained ripple formsets, showing no or limited translation (migration) were interpreted by Kocurek (1981a) as formed under less uniform or less sand saturated conditions than the finer grained ripples forming translatent strata. Stabilization may be a result of armouring by coarser grains, allowing the ripples to grow in height but making them less easily translated. The abundance of these ripple formsets is the most diagnostic feature of these deposits and makes it clearly recognizable from fluvial plane bed deposits.

The irregular lamination exhibits wide variations. The dominant structure is fuzzy, horizontal and inclined lamination (up to $40^{\circ}$ ) in various sand grades (Fig. 38D). These internal structures are associated with bedding planes exhibiting adhesion ripple and wart structures (Fig. 38E). The fuzzy lamination is also commonly associated with more distinct structures such as symmetrical ripple formsets in fine sand, forming an intricate irregular pattern (Fig. 38F), although symmetrical ripple forms also rarely occur as well-developed formsets. Rootlets and burrows are also associated with the fuzzy lamination and with translatent strata, resulting in a disruption of the parent stratification (Fig. 38B). Rootlets sometimes are lined with a millimetre thick calcite layer (Fig. 38B). The irregular lamination is generally composed of poorly sorted sand with varying contents of mud $(0-10 \%)$. When mud occurs desiccation cracks are common.

The fuzzy irregular lamination was deposited as adhesion ripples and warts (Hunter, 1973; Kocurek, 1981b; Kocurek \& Fielder, 1982; Kocurek \& Nielson, 1986; Olsen et al., 1989) as indicated by the association with adhesion surface structures on bedding planes. The inclination of such lamination is the result of upwind migration and climbing of adhesion ripples (Hunter, 1973). The presence of adhesion lamination indicates damp depositional surfaces, prohibiting wind ripple migration. Rootlets and burrows apparently also created some of the irregular lamination, and vegetation may also have created an irregular depositional relief (Kocurek \& Nielson, 1986). At several localities, however, the irregular lamination is probably a combination of several mechanisms also including algal mats, salt ridges and repeated desiccation. Symmetrical ripple forms indicate the presence of wave ripples formed in standing water bodies. The ripple forms are, however, rarely well-preserved. They usually exhibit truncated crests and intimate association with adhesion lamination (Fig. 38F). The wave ripples were, accordingly, deposited in ephemeral ponds in the interdune or sandsheet areas and experienced erosional modification during falling water and modification by adhesion on the damp surface after emergence. Close 

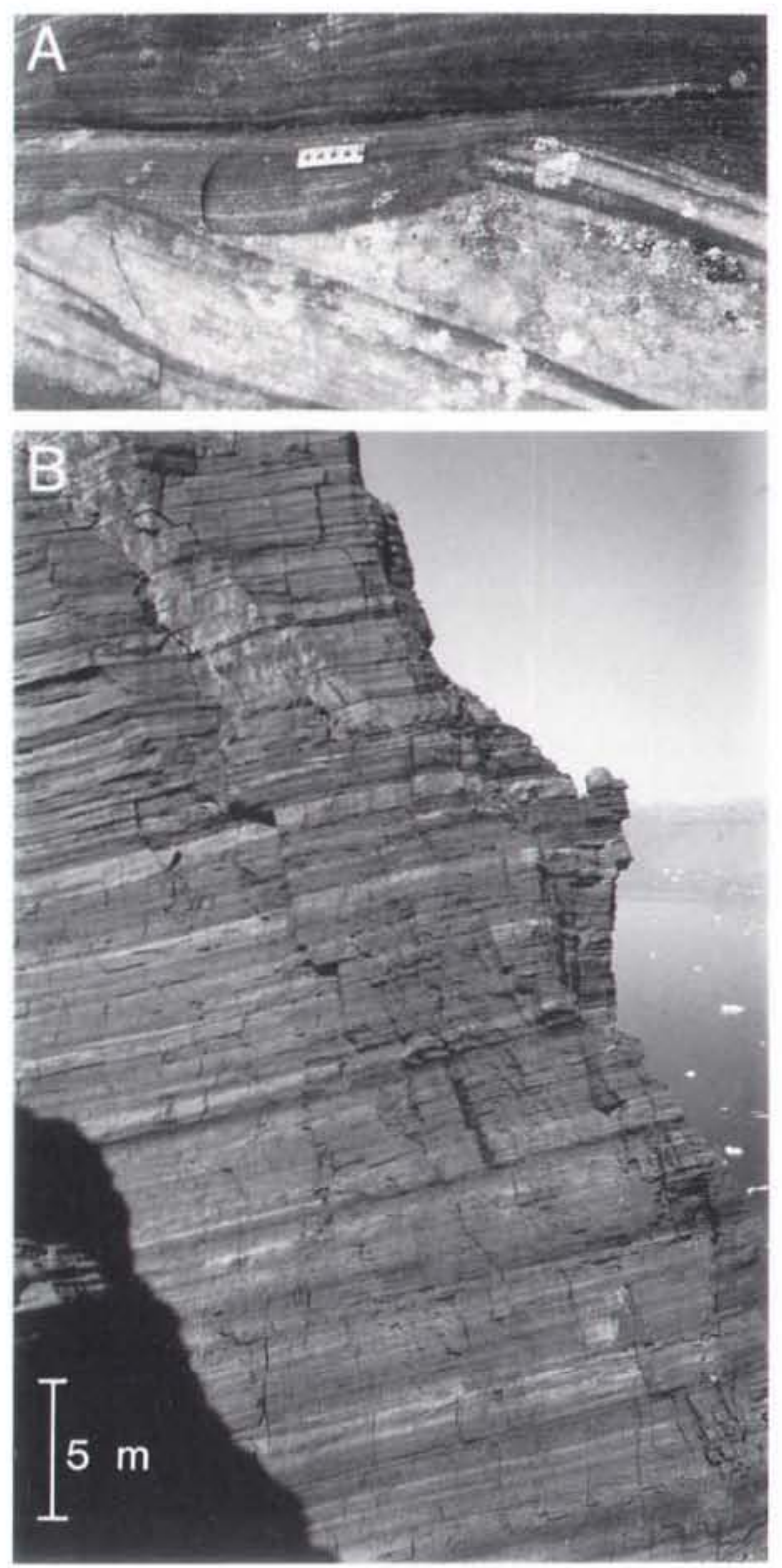

Fig. 39. Aeolian sand sheet/interdune association. (A) Differential erosion of dune deposits. The sandflow strata were preferentially eroded whereas the translatent strata were protected by early differential cementation (Barnabas Dal Formation at Rødebjerg). Ten $\mathrm{cm}$ long measure for scale. (B) A thick succession dominated by aeolian sand sheet deposits with only thin units of dune deposits with visible cross-bedding (Udkiggen Formation at Rodsten).

association with thin beds of the ephemeral stream association shows that flooding and draining by streams also occurred in the interdunes and sand sheets.

Calcrete nodules occur in rare mud-rich (up to 20\%) varieties of the facies implying that the sand supply was extremely low. Such rocks are transitional in character between this facies association and flood basin deposits and show both adhesion lamination, wind ripple formsets and abundance of desiccated mud layers.

When sandstones of the aeolian sand sheet/interdune association overlie aeolian dune sandstones differential erosion of sandflow strata is commonly observed, resulting in a projection of translatent strata of the aeolian dunes into the sand sheet/interdune deposits (Fig. 39A). Also rarely non-erosional draping of underlying bedforms is observed (see Fig. 44F). The top surface of sand sheet/interdune units is commonly erosional. When overlain by aeolian dune deposits the boundary may, however, exhibit a gradual transition from low-angle parallel lamination to high-angle cross-bedding. Differential erosion of sandflow strata has previously been described from modern interdunes and interpreted as wind erosion of dune deposits after early differential cementation of translated strata (Simpson \& Loope, 1985; Schenk \& Fryberger, 1988).

Sand sheet/interdune deposits usually occur in successions $0.1-3 \mathrm{~m}$ thick, and rarely up to $c .10 \mathrm{~m}$ thick. The lateral extent usually exceeds the outcrops (ten to hundreds of metres), though individual sets of parallel laminated sandstone may pass laterally into cross-sets of the aeolian dune association within less than $10 \mathrm{~m}$. Centimetre to decimetre-scale beds, in dominantly fluvial successions may exhibit lateral pinching out within a few tens of metres. The basal bounding surface of sand sheet/ interdune units is usually sharp and erosional. The facies association in general exhibits rapid vertical and lateral transitions between the different component facies. Usually, however, a dominance of either 'dry' facies or 'damp to wet' facies is observed within individual horizons.

A distinction between interdune and sand sheet deposits based solely on the association itself is hardly possible (Ahlbrandt \& Fryberger, 1981: Kocurek, 1986). A diagnostic sequential build-up of interdune deposits into fining upward sequences, as suggested by Clemmensen (1991), was not observed. The association with the dune deposits may, however, give a clue to the depositional environment. When units of dominantly sand sheet/interdune deposits regularly alternate with thick units of aeolian dune deposits the former are interpreted as interdune deposits (Fig. 40). When sand sheet/interdune sandstones occur with only rare thicker dune units (Fig. 39B) they were either deposited as sand sheets or represent amalgamated interdunes during low sand supply (Simpson \& Loope, 1985). Very thin and laterally restricted beds associated with fluvial sandstones represent aeolian reworking and localized sand sheet development. 


\section{Flood basin association}

\section{General characteristics}

The flood basin association is composed of interbedded siltstones, mudstones and very fine to fine-grained sandstones (Figs 41-43). The sediments are usually red coloured but green and grey sediments also occur. Siltstones and mudstones dominate the association, usually forming $50-100 \%$. The facies include a variety of smallscale sedimentary structures and common desiccation cracks, sometimes associated with nodular carbonate or quartz. The facies association records the deposition of fine material in inter-channel areas or down-current of channels, including both terminal flood basins and mud flats marginal to lakes. Collectively the sedimentary environments are termed flood basins. The flood basins were predominantly subaerially exposed.

\section{Previous investigations}

Flood basin mudstone and siltstone deposits form substantial parts of the Cambridge group's red sandstone dominated sample groups $5 \mathrm{~A}$ and $5 \mathrm{~B}$ and the red siltstone dominated sample groups 5C and 5D of Alexander-Marrack \& Friend (1976) and Nicholson \& Friend (1976) and were also mainly interpreted in this way by these authors. Brecciated mudstones, deposited in flood basins or playa mud flats, form part of sample group $4 \mathrm{C}$ (Nicholson \& Friend, 1976) and were interpreted in a similar way. Levee and crevasse splay deposits were not identified by Friend and his co-workers.

\section{Details}

When well-exposed the siltstones and mudstones exhibit brecciated bedding, apparently massive bedding, horizontal lamination, cross-lamination and bioturbation (Figs 4IA, 42A). Unfortunately these deposits very often disintegrate, preventing detailed investigation. The dominant facies is brecciated and apparently massive silty mudstones and siltstones (Fig. 42A). Thin section examination of massive mudstones show that they are in fact brecciated on a submillimetre scale. The mudstones and siltstones occur in beds a few centimetres to several metres thick. The brecciated beds are characterized by a patchy fabric of superimposed millimetre and submillimetre size cracks. In thin section it is observed that the cracks are commonly filled with clay and diagenetic quartz. In less densely brecciated beds individual cracks can be recognized as desiccation cracks and on rare bedding planes complex polygonal patterns of cracks can be seen. In homogeneous siltstone or mudstone units desiccation cracks are only rarely observed, but at sand-

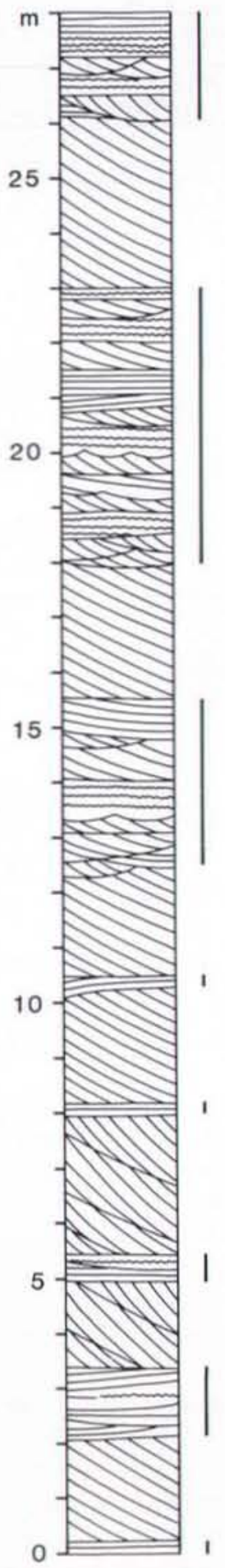

Fig. 40. Graphical section through a part of the Barnabas Dal Formation. An alternation between cross-bedded (acolian dune) and heterogeneous (interdune) units is observed. The interdune units, which are dominated by low-angle parallel lamination and small dune cross-beds, are indicated by bars. 


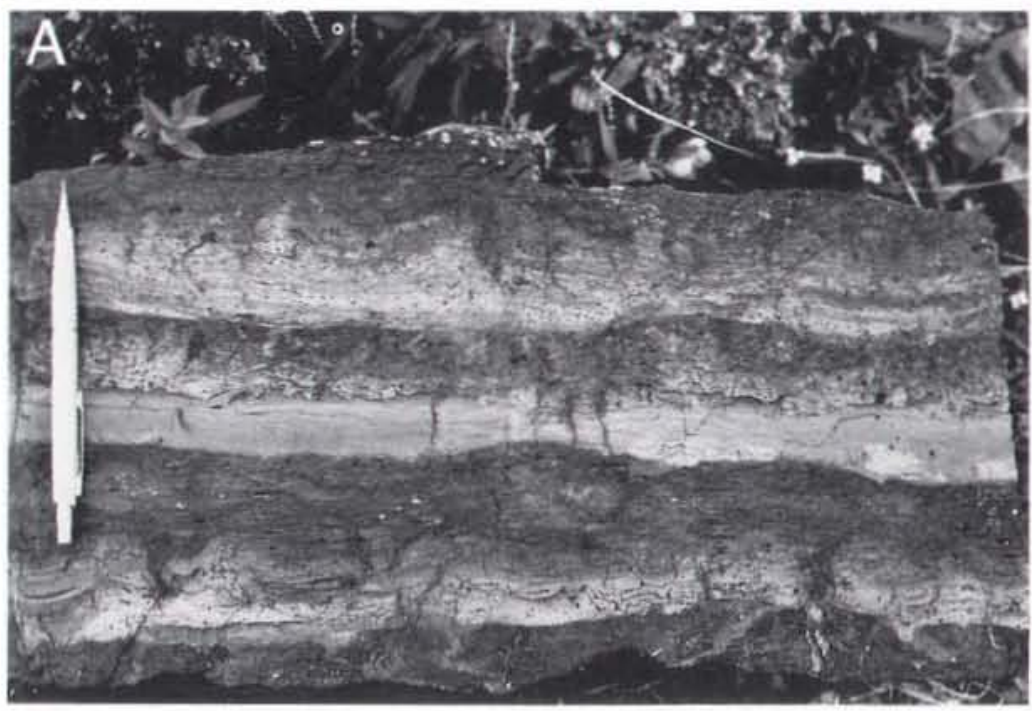

Fig. 41. Flood basin association. (A) Siltstones (light coloured) and mudstones exhibiting horizontal lamination, brecciated bedding and apparently massive bedding. Desiccation cracks are observed due to colour contrasts. (Aina Dal Formation at Stensiō Bjerg). Pencil is $14 \mathrm{~cm}$ long. (B) Desiccation cracks in siltstone. Notice the lighter coloured calcrete nodules (arrows). Measure is $10 \mathrm{~cm}$ long. (Agda Dal Formation at Agda Dal.)

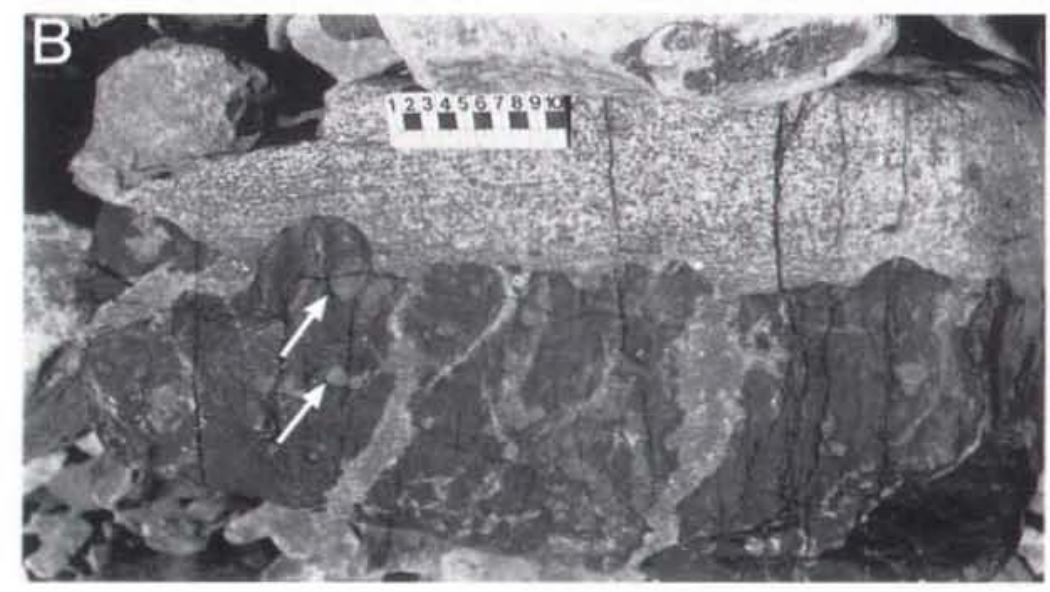

stone contacts and in heterolithic siltstone-mudstone units desiccation cracks are very commonly seen due to colour and grain size contrast (Figs 41A, B).

The brecciated bedding may partly be due to bioturbation (e.g. Farrell, 1987) but probably was caused mainly by repeated desiccation (e.g. Hardie et al., 1978; Smoot, 1981: Demicco \& Kordesh, 1986; Rust \& Nanson, 1989). The latter process may be promoted by expansion of the sediment during wet periods due to the presence of swelling clays (Bridges, 1970).

Calcite occasionally occurs as a nodular mineral in the brecciated mudstones, forming centimetre sized concretions (Fig. 41B) or rarely sheets up to $10 \mathrm{~cm}$ thick. Submillimetre to millimetre size nodules of carbonate (calcite and dolomite) or quartz were observed in some intervals of brecciated mudstones occasionally resulting in a fenestral fabric (Fig. 42B). These nodules may be associated with dolomite rhombs. However, both the nodules and rhombic crystals are usually scattered and too small to be seen with the naked eye and it is suspected that they commonly occur as minor constituents in the massive to brecciated mudstones.

The centimetre size concretionary calcite nodules and sheets observed in siltstone intervals are interpreted as calcretes (Allen, 1974, 1986; Leeder, 1975) implying reduced sediment supply and well drained flood basins formed by combined evaporitic pumping of groundwater and $\mathrm{CO}_{2}$-removal by plants (Leeder, 1975; Allen \& Collinson, 1986; Wright et al., 1988). The small scattered carbonate and quartz nodules probably represent very immature calcretes. The original calcite or high-Mg calcite was partly replaced diagenetically by dolomite and quartz. The depositional environment may have been either the interchannel areas or playa-like terminal mud flats. The rare fenestral fabric of nodule-rich mudstones resemble rhizolite calcretes described by Wright et al. (1988) (compare Fig. 42B with their figs $3 \mathrm{a}$ and $10 \mathrm{a}$ ). Rhizolite calcretes are formed as calcified root-mats in flood basin and lake margin deposits. In relatively homogeneous deposits they may form in areas with very shal- 

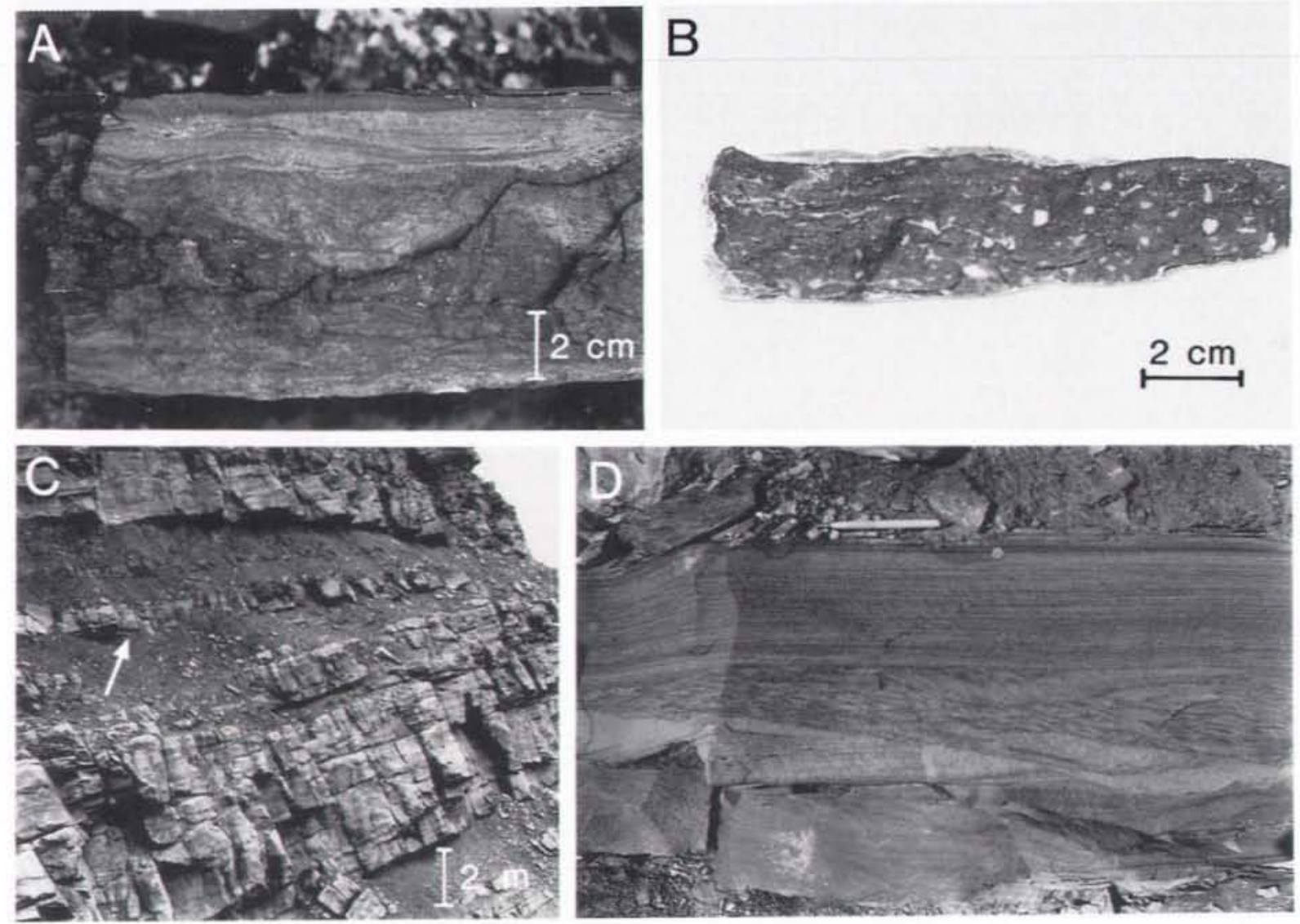

Fig. 42. Flood basin association. (A) Close-up of a mudstone bed exhibiting brecciated bedding (Aina Dal Formation at Stensiö Bjerg). (B) Brecciated mudstone with millimetre size nodules, forming a fenestral fabric (Wimans Bjerg Formation at Obrutschew Bjerg). (C) Flood basin and meandering river deposits. A thick tabular sandstone (point bar) is embedded in flood basin deposits, mainly siltstones (recessive). A sheet sandstone (arrowed) of crevasse splay origin is observed in the upper flood basin unit. (Andersson Land Formation west of Zoologdalen.) (D) Close-up of a crevasse splay sandstone body. Notice, in the lower part. troughs partly filled with cross-laminated sand. (Andersson Land Formation west of Zoologdalen.) Pencil is $14 \mathrm{~cm}$ long.

low seated water tables; roots extend to the water table where they form interwoven horizontal rootlet systems (Wright, et al., 1988). The fenestral fabric in brecciated mudstones may thus indicate the long-term presence of shallow phreatic waters in interchannel mud flats or mud flats surrounding lakes. The original calcite nodules, accordingly, must have been partly replaced by diagenetic dolomite and quartz.

An alternative explanation of the nodule-rich brecciated mudstones is a playa mud flat origin (e.g. Hardie $e t$ al.. 1978; Smoot, 1981; Demicco \& Kordesh, 1986). The nodules may thus be primary carbonate nodules and/or represent former gypsum nodules, now replaced diagenetically by other minerals. Detailed thin section examination to test this model has, however, not been carried out. Although some of the brecciated mudstones share characteristics with playa mud flats, the absence of associated saline lake or salt pan deposits in the Devonian basin differs from the traditional setting of playa deposits. The sediments occur in association with both fluvial channel deposits (ephemeral stream association) and ephemeral lake deposits (lacustrine association). Alluvial floods either lateral or terminal to channellized streams are considered responsible for the clastics in both settings, and the sediments are thus classified as flood basin deposits.

The sandstones occur either as solitary decimetre thick bodies or as part of heteroliths (rare). The sandstone bodies are less than $1 \mathrm{~m}$ thick, tabular (Fig. 42C) or rarely channel-shaped, erosional or, commonly, non-erosional and commonly fining upwards (Fig. 43). The sedimentary structures include horizontal lamination, troughs with concordant (sometimes cross-laminated) or low-angle cross-bedded fill (festoon cross-bedding), cross-lamination, scour-and-fill structures and massive bedding (Figs 42D, 43). Desiccation cracks, thin sandstone layers 


Claystones, mudstones, siltstones and shales
$\square$ Heterolith
$\square$ Sandstones
$\square$ Pebbly sandstones
$\ldots$.
$\ldots$ Sandstones with intraformational clasts
$\because \%$ Conglomerates

\section{SEDIMENTARY STRUCTURES}

Brecciated bedding

Massive bedding

Parallel lamination

Undifferentiated structures in claystones etc.

$\because \because$ Cross-lamination (current ripples)

Low-angle inclined lamination

Festoon cross-bedding
Trough cross-bedding
Planar cross-bedding
Deformed bedding
Sarallel lamination (aeolian)

\section{MISCELLANEOUS FEATURES}

$\nearrow$ Current direction from cross-lamination

D. Current direction from cross-bedding

Current sense from parting/streaming lineation

7 Current direction from imbrication

ॠ Current direction from wave ripples

$\checkmark$ Desiccation cracks

人 Rootlets

S Burrows

$\oplus$ Calcrete nodules

(8) MPS (mean of ten largest particles, locally)
Axact Wave ripple lamination and draped lamination

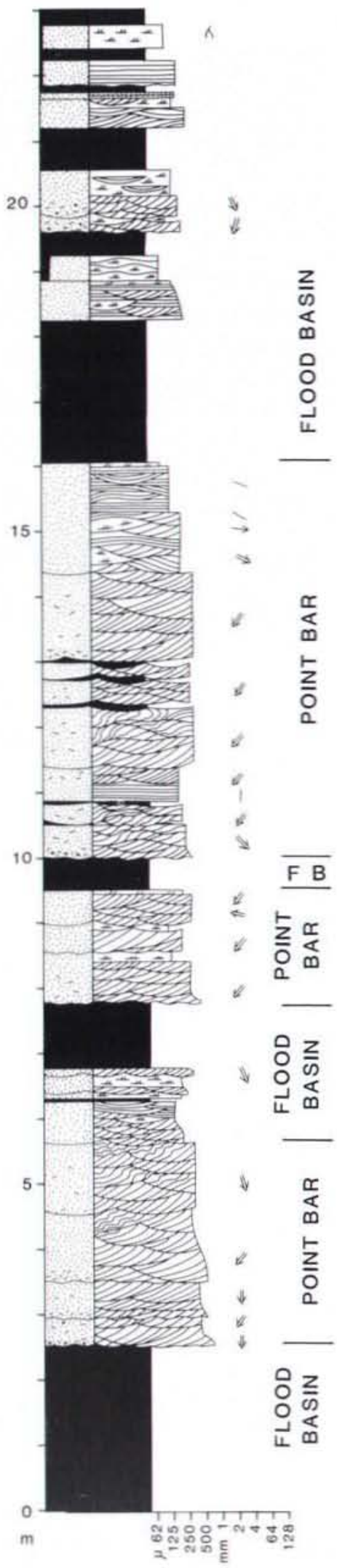

Fig. 43. Alternating flood basin and meandering river (point bar) deposits. Several crevasse splay sandstones are present in the uppermost flood basin unit. (Andersson Land Formation west of Zoologdalen.) 
with translatent strata and rootlets are common at the top of the sandstone bodies. Commonly the sandstone bodies occur in successions of $2-5$ units, separated by centimetre to decimetre thick siltstones.

The sandstone bodies are interpreted as crevasse splay deposits (cf. Elliott, 1974; Farrell, 1987). The upward fining reflects the decelerating nature of the flows, which were very shallow as judged from the sedimentary structures. Desiccation cracks, rootlets and translatent strata indicate subaerial exposure of the splays. The flows were mainly unchannellized, indicated by their tabular form (Tunbridge, 1981; Bridge, 1984) and the apparently nonerosional base of several beds (Tunbridge, 1981). Channel-shaped beds are interpreted as channellized crevasse splay deposits (Bridge, 1984). The crevasse splay deposits are similar to some of the sandstones in the ephemeral stream association. However, they are always associated with flood basin mudstones and sandstones of the meandering river association, and in contrast to the ephemeral stream deposits, the sandstone bodies rarely amalgamate to form thicker successions.

The heteroliths are composed of cross-laminated very fine-grained sandstones and desiccation cracked siltstones interbedded on a centimetre scale. The bedding is usually horizontal and heterolithic successions may exhibit coarsening upwards. These sediments closely resemble levee deposits described by Elliott (1974) and Farrell (1987).

\section{Ephemeral stream association General characteristics}

Deposits of this association are usually red coloured and exhibit a variety of sedimentary features (Figs 44 47). The deposits group into three sediment body types: (1) aggraded broad channel-shaped sandstone bodies, (2) thin tabular sandstone sheets and (3) laterally accreted sediment bodies. Siltstone intraclasts and desiccation cracked siltstone layers are common within and between the sediment bodies. The sedimentary characteristics and close association to aeolian sand-sheet deposits suggest an ephemeral stream origin.

\section{Previous investigations}

Alexander-Marrack \& Friend (1976) identified sheetflood deposits of ephemeral stream origin as parts of their sample groups IB, 7A-C and 8. Yeats \& Friend (1978) also interpreted some of their sample groups as partly formed by sheetfloods (e.g. sample group 5A). However, investigations by the present author show that at least some of the parallel laminated sandstones, interpreted in terms of sheetfloods by these authors, were deposited as aeolian sand sheets. Sample groups $2 \mathrm{~A}$ in Nicholson \& Friend (1976) and $4 \mathrm{~F}$ in Alexander-Marrack \& Friend (1976) resemble the low-sinuosity ephemeral stream deposits described in this paper, although a precise interpretation was not made by these authors. Sample groups 5C and 5D were according to Nicholson \& Friend (1976) partly deposited in meandering ephemeral streams, in accordance with the interpretation of the present author.

\section{Details}

Channel-shaped sandstone bodies with aggraded deposits are very common in the ephemeral stream association and are typically fine to medium-grained, fining upwards and dominated by trough cross-bedding (Figs 44C, E, F, 45), Commonly the cross-set thickness decreases upwards and the upper part of the sandstone body may be composed of cross-lamination (Fig. 44C). Locally cross-laminated, parallel laminated (horizontal and low-angle inclined) and massive bedded sandstone dominate, and rarely conglomerates are observed. Bases of sandstone bodies are erosive but local relief rarely exceeds $10 \mathrm{~cm}$. The sediment bodies are generally broadly channel-shaped and commonly appear tabular within limited outcrops. Intraformational siltstone clasts abound. Siltstones also commonly cap sandstone bodies and usually exhibit desiccation cracks (Fig. 44D). A common feature of the upper $c .10 \mathrm{~cm}$ of the sandstone bodies is the presence of rootlet horizons (Fig. 44E). The sandstone bodies commonly occur solitary, less than $1 \mathrm{~m}$ thick (varying from $0.1 \mathrm{~m}$ to $2 \mathrm{~m}$ ) with siltstone or aeolian sand sheet interbeds (Fig. 44F). They may, however, also form 1-6 $\mathrm{m}$ thick multistorey bodies of stacked decimetre to metre-scale sandstone stories with few, sometimes desiccation cracked siltstone interbeds, embedded in flood basin or aeolian sandsheet deposits, (Figs 45, 46A).

The aggraded sandstone bodies are interpreted in terms of low-sinuosity ephemeral streams dominated by 3-D dunes (e.g. Williams, 1971; Picard \& High, 1973; Parkash et al., 1983). The streams were poorly defined or wide channels resulting in the general sheet-like geometry of the sandstone beds. The upwards fining and decrease in trough set thickness or transition into crosslamination indicate deceleration of floods. Between individual floods the channels were commonly stabilized by a plant cover or exposed to aeolian reworking and infilling of aeolian sand. The multistorey sandstone bodies are interpreted as deposited within larger channels with ephemeral flow. The stories reflect either deposition in component channels within a main channel (Allen, 1983; Olsen, 1989) or successive flood infillings of a larger channel feature - or a combination (cf. Tunbridge, 1984).

Decimetre-thick vertically accreted very fine to me- 

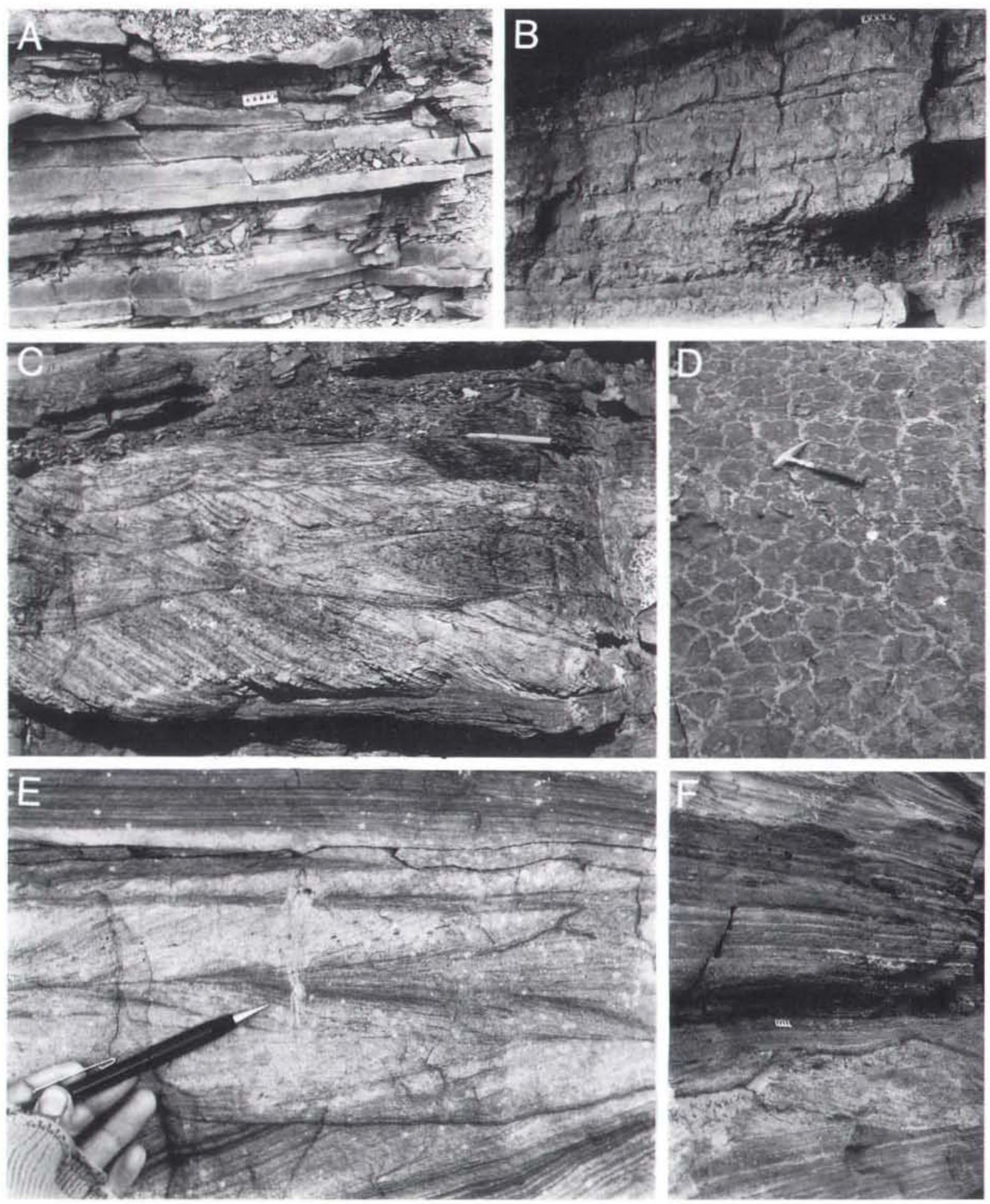

Fig. 44. Ephemeral stream association. (A) Thin tabular sandstone sheets dominated by horizontal parallel lamination (Ankerbjergselv Formation at Ankerbjergselv). Measure is $10 \mathrm{~cm}$. (B) Thin tabular sandstone sheets with desiccation cracked siltstone interbeds (Rødebjerg Formation at Rødebjerg). Measure in upper right is $10 \mathrm{~cm}$ long. (C) Aggraded broad channel-shaped sandstone body (Rodebjerg Formation at Rødebjerg). The sediments fine upwards and cross-set thickness decreases. The topmost part of the bed is composed of cross-laminated sandstone. Pencil in upper right is $14 \mathrm{~cm}$ long. (D) Siltstone bed in top of an aggraded channel- 


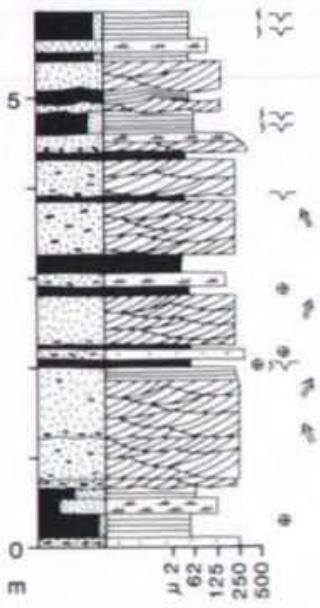

Fig. 45. Ephemeral stream association. A succession dominated by aggraded broad channel-shaped sandstone bodies. (Agda Dal Formation exposed in Agda Dal.) Legend: see Fig, 43.

dium-grained tabular sandstone sheets are common (Figs 44A, B). The sandstone bodies are non- or weakly erosional and commonly composed of only one sedimentary facies. The dominant sedimentary structure is horizontal, parallel lamination, but low-angle parallel lamination, festoon cross-bedding, cross-lamination and massive bedding also commonly occur. The sandstone bodies either fine upwards or are non-graded. Millimetre to centimetre-thick siltstone beds are commonly interbedded. The siltstones usually exhibit desiccation cracks (Fig. 44B). Sometimes individual sandstone bodies are difficult to perceive due to the lack of irregular erosional bases and siltstone partings. Furthermore, such sandstone successions often exhibit complex interbedding of horizontal lamination, low-angle inclined lamination, including concave-up and convex-up laminae, and concordant infilling of shallow trough-forms (festoon cross-bedding). Splitting along bedding planes, however, may reveal evidence of tiny desiccation cracks or small symmetrical (wave) ripple forms, indistinguishable in vertical exposures. Parting lineation is also commonly observed on internal bedding planes of all these lamination types.

The thin tabular sandstone sheets bear similarities with ancient supposed sheetflood deposits (Leeder, 1973; Steel \& Aasheim, 1978; Tunbridge, 1981, 1984; Clem-

\section{Fig. 44. Cont.}

shaped sandstone body (Rødsten Formation at Rødsten). Pencil is $14 \mathrm{~cm}$ long. (F) An aggraded channel-shaped sandstone body (lower part of photograph) enclosed in aeolian sand sheet deposits (Rødebjerg Formation at Rodebjerg). Notice the preservation of the morphology of subaqueous dune bedforms. Measure is 10 $\mathrm{cm}$ long. mensen et al., 1989; Olsen, 1989). The dominance of horizontal lamination with parting lineation indicates upper flow regime plane bed conditions probably due to very shallow flow depths (centimetres to decimetres).

Laterally accreted sediment bodies consist of channelshaped coarse siltstone and very fine sandstone. They are characterized by inclined bedding. dipping 6-20 degrees (generally $<10$ degrees) in one direction throughout the whole body and perpendicular to the inferred current direction (Fig. 46B). The sediment bodies are usually less than $1 \mathrm{~m}$ thick but range from $0.5 \mathrm{~m}$ to rarely $4 \mathrm{~m}$ and occur solitary or as part of multistorey bodies. The sediment bodies are composed of decimetre-scale inclined bedsets, commonly exhibiting fining upwards (Fig 47). Sedimentary structures are mainly cross-lamination. Par-
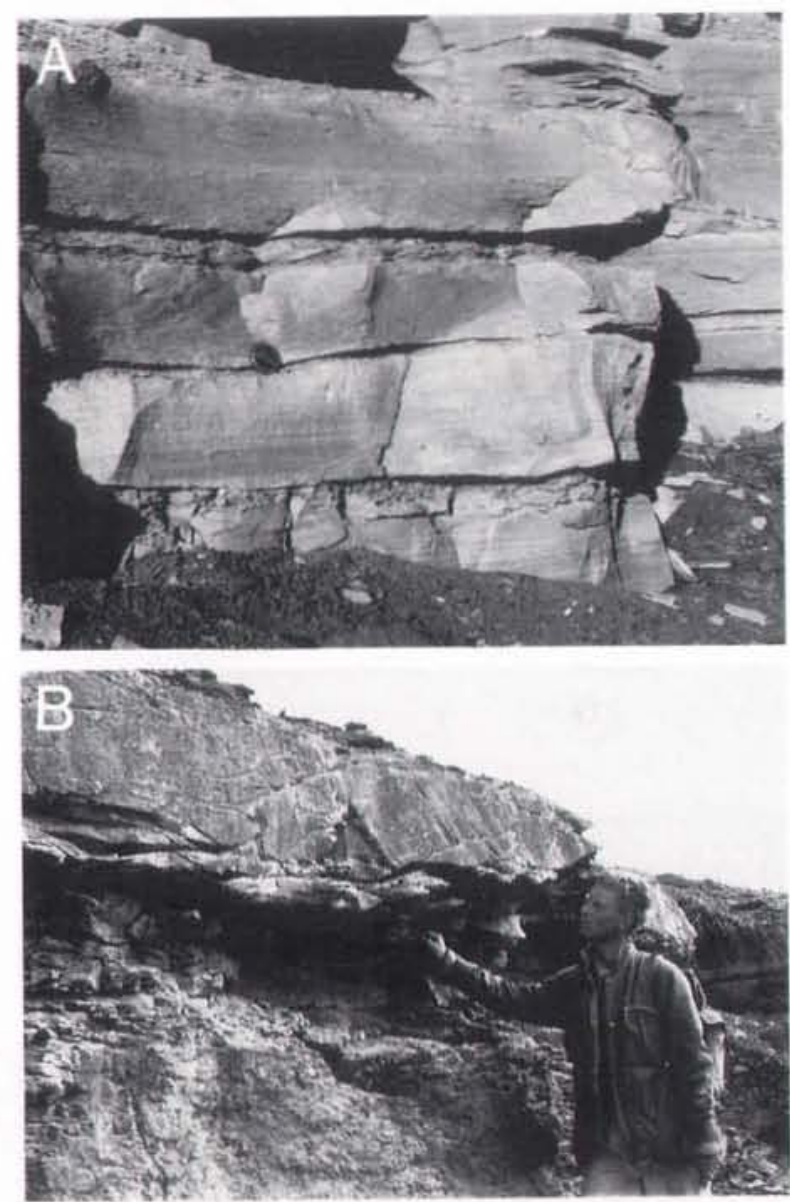

Fig. 46. Ephemeral stream association. (A) Stacked deposits of broad channel-shaped sandstone bodies, probably recording repeated floods in a stationary channel (Zoologdalen Formation. west of Zoologdalen). Lens cap is $5.5 \mathrm{~cm}$. (B) Channel-shaped siltstone body with lateral accretion bedding (Wimans Bjerg Formation, Stensiö Bjerg). The sediment body was deposited as a point bar in an ephemeral meandering stream. Palaeoflow into the exposure. 


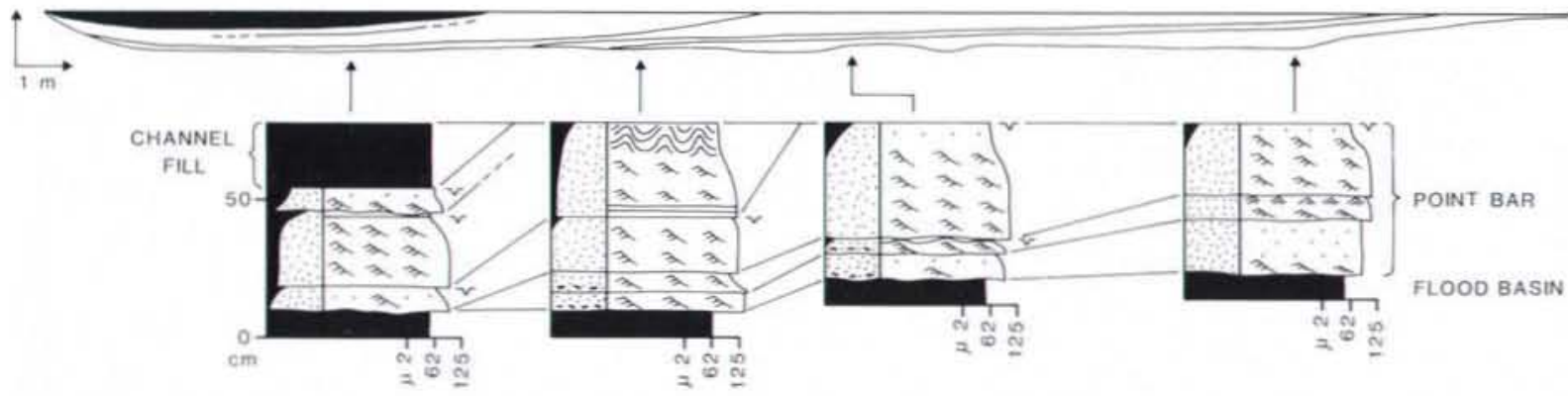

Fig. 47. Ephemeral stream association. A channel-shaped sediment body with lateral accretion bedding. Aina Dal Formation at Stensiö Bjerg. Notice the desiccation cracks in top of bedsets. The sediment body was deposited during several floods in a small ephemeral meandering stream. Palaeoflow into the exposure. Legend: see Fig. 43.

allel lamination, massive bedding and bioturba-tion are also observed. Symmetrical ripple formsets occasio-nally occur on top of bedsets. Commonly mudstone layers separate individual bedsets and very often exhibit desiccation cracks.

These sediment bodies indicate lateral accretion on point bars in meandering streams. The bedset build-up and internal desiccation cracked layers indicate highly fluctuating to ephemeral discharge conditions and the sediment bodies find close analogues in modern meandering ephemeral streams (Picard \& High, 1973) and inferred ancient ephemeral streams (Olsen, 1989). The channels were generally shallow and current velocities moderate as indicated by the fine grain size and dominance of cross-lamination.

Sheetflood deposits, low-sinuosity ephemeral stream deposits and meandering ephemeral stream deposits are transitional to the flood basin association the braided river association and the meandering river association, respectively.

\section{Meandering river association General characteristics}

This facies association is composed of tabular sandstone bodies dominated by inclined, lateral accretion bedded storeys and mainly composed of very fine to medium-grained sandstones (Figs 43, 48-50). The association is interpreted as perennial meandering river deposits. The sediments are usually red but green, grey and yellow varieties also occur.

\section{Previous investigations}

Meandering river deposits were identified by Nicholson \& Friend (1976) and classified as part of their sample group $5 \mathrm{~A}$, in association with flood basin mudstones.

\section{Details}

This facies association consists of laterally accreted fine- to medium-grained sandstone storeys. The storeys are tabular, $1.5 \mathrm{~m}-10 \mathrm{~m}$ thick and tens to hundreds of metres in lateral extent usually exceeding the outcrops. Along the basal erosion surface, intraformational mudstone clasts are common, extraformational granules and pebbles are rare. Mean grain size commonly fines upwards through a storey (Fig. 43). The lower and middle part of the sandstone storeys is usually dominated by trough cross-bedding, whereas the upper part is commonly composed of interbedded parallel laminated. through cross-bedded, and cross-laminated sandstone. Centimetre thick discontinuous layers of mudstone are rare to common and may occasionally exhibit desiccation cracks in the upper parts of storeys. Very fine-grained sandstone storeys may be dominated or entirely composed of cross-laminated sandstone. The inclined bedding is usually composed of bedsets decimetres to metres thick, bounded by erosion surfaces which extend from the top to the base of the storey over distances of metres to tens of metres (Fig. 48B,C,D,E). Mean values of inclination relative to the basal erosion surface are in the range of $5^{\circ}$ to $12^{\circ}$. The surfaces are commonly slightly convex-up or sigmoidal. The bedsets usually fine upwards (perpendicular to the bedding) and are in places topped by thin siltstone layers (Fig. 43). The fining upwards is commonly associated with a decrease in trough set thickness or a transition from trough cross-bedding to parallel lamination or cross-lamination (Fig. 49). Palaeocurrent direction is generally perpendicular to the dip direction of the inclined bedding.

Inclined bedding is in places associated with channel fills (Fig. 48B). The fills may be composed either of a fining-upward sandstone unit with a gradual transition to the associated inclined bedding or composed mainly of siltstone with an abrupt contact. The fills also locally 

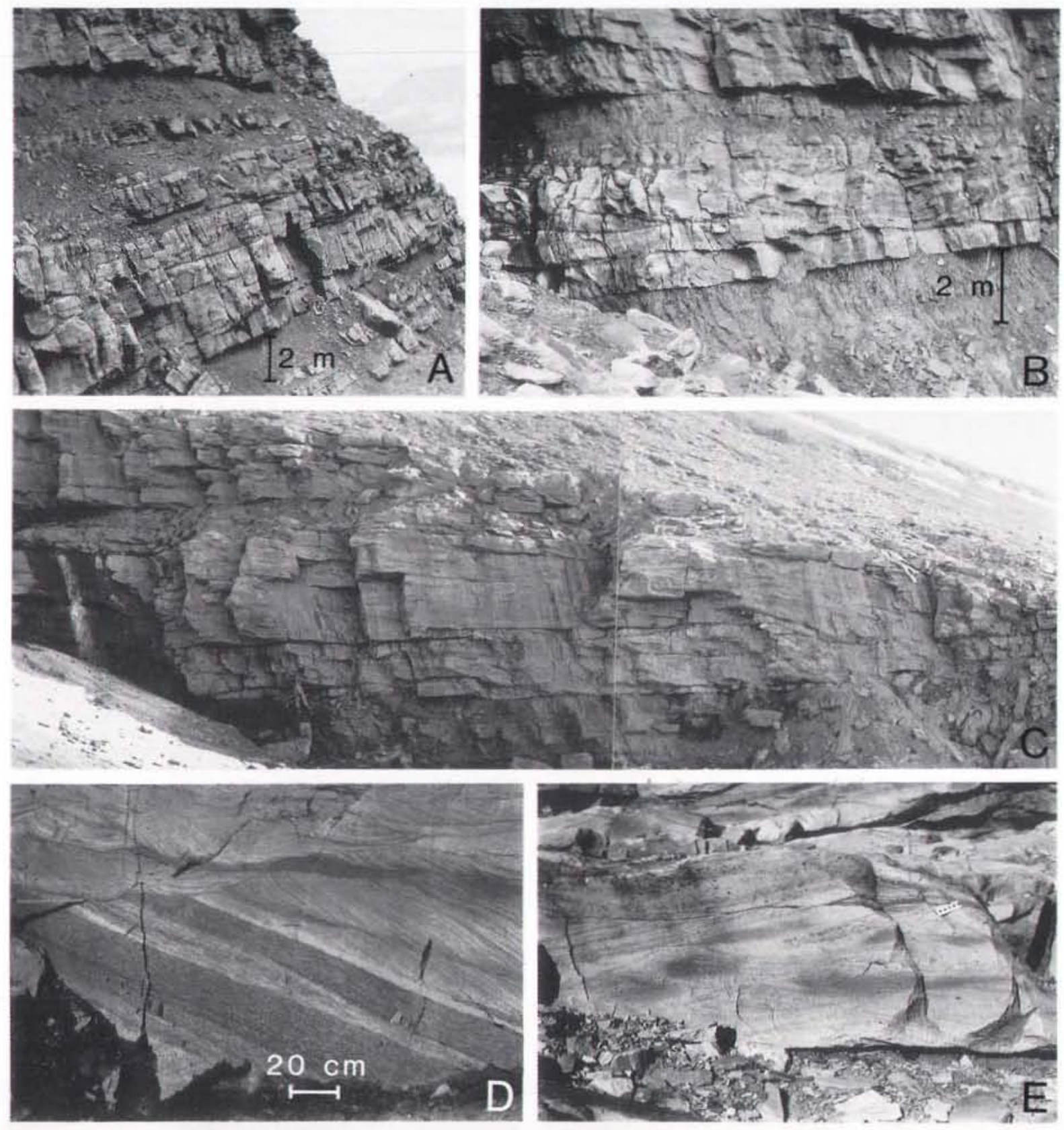

Fig. 48. Meandering river and flood basin deposits (Andersson Land Formation west of Zoologdalen). (A) Thick tabular sandstone body (point bar) embedded in flood basin deposits, mainly siltstones. Palaeocurrents are parallel to the exposure. (B) A multistorey tabular sandstone body embedded in flood basin siltstones. Three storeys are observed each representing a point bar. Notice the lateral accretion bedding in the uppermost storey, inclined towards the right and grading into a channel fill. Notice also channel incision at the base of the channel fill. Palaeocurrent in the uppermost storey is almost directly out of the cliff face. (C) Tabular sandstone body composed of two storeys. Notice the well developed lateral accretion bedding dipping to the right in the uppermost storey. Palaeocurrents in upper storey are towards the viewer. Person for scale in the lower left at the base of the sandstone body. (D) Close-up of lateral accretion bedding cut by a horizontal erosion surface. The lateral accretion dips at an apparently higher angle due to an oblique view of the outcrop. The lateral accretion bedding is dominated by cross-lamination in the lower/left part and trough cross-bedding in the upper/right part. Palaeoflow out of the exposure. (E) Close-up of lateral accretion bedding inclined to the left and composed of trough cross-bedding. Palaeoflow out of the exposure. Measure is $10 \mathrm{~cm}$ long. 


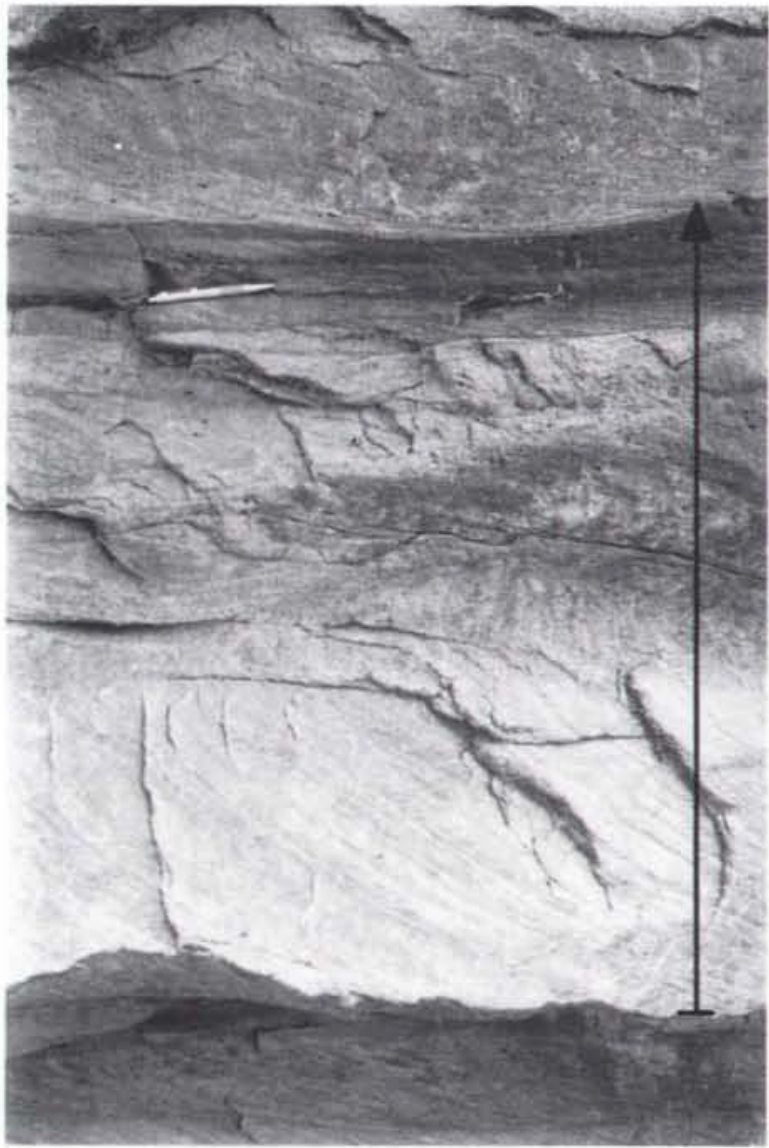

Fig. 49. Meandering river association. A fining upward bedset exhibiting upward decreasing trough set thickness and transition to cross-lamination in the top. The bedset is erosionally overlain by another bedset with trough cross-bedding at its base. (Andersson Land Formation west of Zoologdalen.) Pencil, $14 \mathrm{~cm}$ long for scale.

exhibit upward transitions to crevasse splay sandstones of the flood basin association (Figs 43, 48B).

The facies association finds close analogues in modern single-channel meandering rivers (e.g. Steinmetz, 1967; Jackson, 1975, 1976; Shepherd, 1987) and ancient inferred meandering river deposits (e.g. Allen, 1965, 1970; Moody-Stuart, 1966: Beutner et al., 1967; Leeder, 1973; Puigdefâbregas, 1973; Puigdefabregas \& van Vliet, 1978; Bridge \& Diemer, 1983). The relationship between the inclined bedding and palacocurrents indicate that deposition occurred as lateral accretion on point bar surfaces parallel to the inclined bedding. Individual bedsets were probably deposited during individual major flood events (cf. Steinmetz, 1967: Daniel, 1971; Bridge \& Diemer, 1983). Signs of emergence of the bar surfaces only occur in the uppermost bar deposits. The rivers, accordingly, are interpreted as perennial.

The thickness of individual complete point bar depos- its and channel fills indicate channel depths ranging from $1.5 \mathrm{~m}$ to $10 \mathrm{~m}$. The river width may be estimated from the point bar slope and associated thickness, indicating widths in the range of a few tens of metres to more than $100 \mathrm{~m}$.

The sandstone storeys commonly amalgamate vertically to form multistorey bodies, composed of 2-3 storeys, each representing a point bar and separated by horizontal erosion surfaces (Fig. 48B,C). The multistorey build-up is the expected result of lateral, probably downvalley, meander loop migration during net aggradation (Beerbower, 1964: Bluck, 1971; Bridge, 1975; Bridge \& Leeder, 1979; Bridge \& Diemer, 1983). Palaeocurrent directions from superimposed storeys may vary as much as $150^{\circ}$. interpreted as the result of curvature of the migrating meanders.

The meandering river association is closely associated with the flood basin association and may form succes-

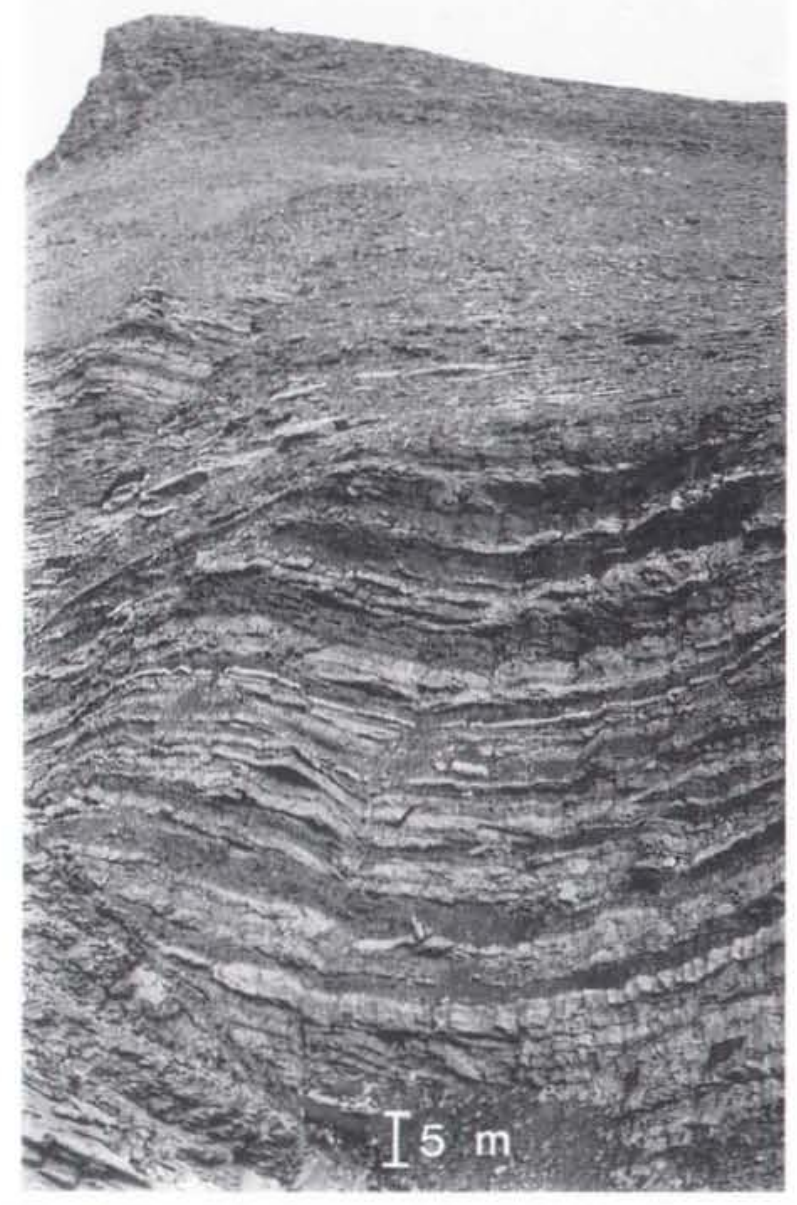

Fig. 50. Meandering river association. Typical outcrop pattern (looking obliquely up) exhibiting tabular sandstone bodies (light coloured) with interbedded flood basin fines (Midnatspas Formation between Midnatspas and Zoologdalen). 
sions of alternating tabular meandering river sandstones and flood basin mudstones up to several hundred metres thick (Figs 43, 50). It is transitional to subtypes of the ephemeral stream and braided river associations.

\section{Sandy braided river association General characteristics}

The sandy braided river association (Figs 51-53) is built up of multistorey successions of erosionally, broad channel-shaped sandstone storeys. The sediments are composed of fine to very coarse-grained pebbly sandstones and local conglomera-te beds, and trough crossbedding is the dominant sedimentary structure. The facies association is interpreted as deposits in perennial, braided sand-bed rivers dominated by braid bar complexes with superimposed 3-D dunes. The sediments are white to yellowish white, grey, green and red.

\section{Previous investigations}

Sandy braided river deposits were identified by $\mathrm{Ni}$ cholson \& Friend (1976). Yeats \& Friend (1978) and Friend $e t$ al., (1983) and classified as sample groups 2C, 2E, 3D 3C, and 7D. Some aeolian dune deposits, recognized by the present author were, however, misinterpreted as braided river deposits by these investigators. In general, aeolian dune deposits with sets less than $1 \mathrm{~m}$ thick were interpreted as fluvial by the previous investigators. Aeolian dune deposits with set thickness in excess of $1 \mathrm{~m}$ were correctly interpreted as aeolian in origin (e.g. Friend et al., 1983) but classified as the same sample groups as the braided river deposits.

\section{Details}

This association is characterized by punctuated fining upward, very broad channel-shaped to sheet-like storeys which may be up to $10 \mathrm{~m}$ thick, but usually range from 3 $\mathrm{m}$ to $6 \mathrm{~m}$ in thickness. Lateral extent of storeys usually exceeds the outcrops (tens to hundreds of metres) both in down-current and transverse sections. The storeys are separated by scoured surfaces with local down-cutting of less than $0.5 \mathrm{~m}$. Occasionally the association occur as tabular, 3-8 $\mathrm{m}$ thick multistorey sandstone bodies, embedded in sheetflood sandstones or flood basin mudstones (Kelly \& Olsen, 1993). Usually, however, the association occurs as tens to hundreds of metres thick multistorey successions without distinguishable sediment bodies.

Internally, the storeys are dominated by cosets of typically $10-30 \mathrm{~cm}$ thick (medium-scale) trough sets (Fig. 51A). Set thickness may, however, range from $5 \mathrm{~cm}$ to 70 $\mathrm{cm}$ and commonly exhibit upward thinning within individual storeys (Fig. 52). Typical lateral dimensions are $1-3 \mathrm{~m}$ in length and $0.4-1 \mathrm{~m}$ in width. Foresets are concave and usually inclined less than 20 degrees. The individual foreset laminae are commonly indistinct (Fig. 51B).

Large-scale trough and planar wedge-shaped cross-sets also commonly occur. They generally occupy a position in the lower part of storeys (Fig. 52B) but exceptions are common. The cross-sets are usually $50 \mathrm{~cm}$ to $150 \mathrm{~cm}$ thick, more than $10 \mathrm{~m}$ wide and c. $10 \mathrm{~m}$ to more than 30 $\mathrm{m}$ long (Figs 51C, D, E). The cross-sets usually occur singly or form part of cosets composed of 2-3 cross-sets. The foresets are concave or tangential and commonly inclined more than 20 degrees. Individual foreset laminae are usually rather distinct. Simple reactivation surfaces and periodically spaced foreset drapes of fine-grained material are locally abundant (Fig. 51E).

In exceptionally exposed outcrops, down-current dipping bounding surfaces from top to bottom of storeys are observed, associated with descending medium-scale cross-bedding. Occasionally such storeys may be traced upcurrent into large-scale solitary cross-sets of similar size.

Storey-scale thick units with lateral accretion bedding (inclined $\left\langle 15^{\circ}\right.$ ) is always local in character and usually extend for less than $10 \mathrm{~m}$ laterally (Fig. 51F). The bedding is characterized by inclined parallel lamination and medium-scale trough cross-bedding.

The facies association finds close analogues in modern sandy braided perennial rivers dominated by 3-D dunes (e.g. Collinson, 1970; Bristow, 1987; Singh et al., 1993) and ancient inferred braided rivers (e.g. Miall, 1977; Cant \& Walker, 1978; Allen, 1983). Although downstream accretion in individual storeys was only observed in exceptionally well-exposed outcrops, e.g. in the Rødebjerg Formation (Kelly \& Olsen, 1993), the upward thinning of sets or fining upward lithology are mainly interpreted as downstream accreting braid bar complexes. The braid bar lee sides were only weakly inclined, undetectable in the majority of outcrops but locally slipfaces were developed (solitary sets). Channel fills solely composed of bedform deposits, however, probably also occur. Lateral accretion was absent to locally abundant in these rivers, comparing closely with modern braided rivers described by e.g. Bristow (1987). The thickness of fining upward storeys and lateral accretion units, usually $3-6 \mathrm{~m}$, indicate the minimum height of braid bars and channel depths. Punctuated fining upwards of storeys is interpreted to reflect deposition during successive floods, each represented by a bedset.

The form, size and distribution of large-scale trough or planar cross-sets indicate an origin mainly as quasi-peri- 

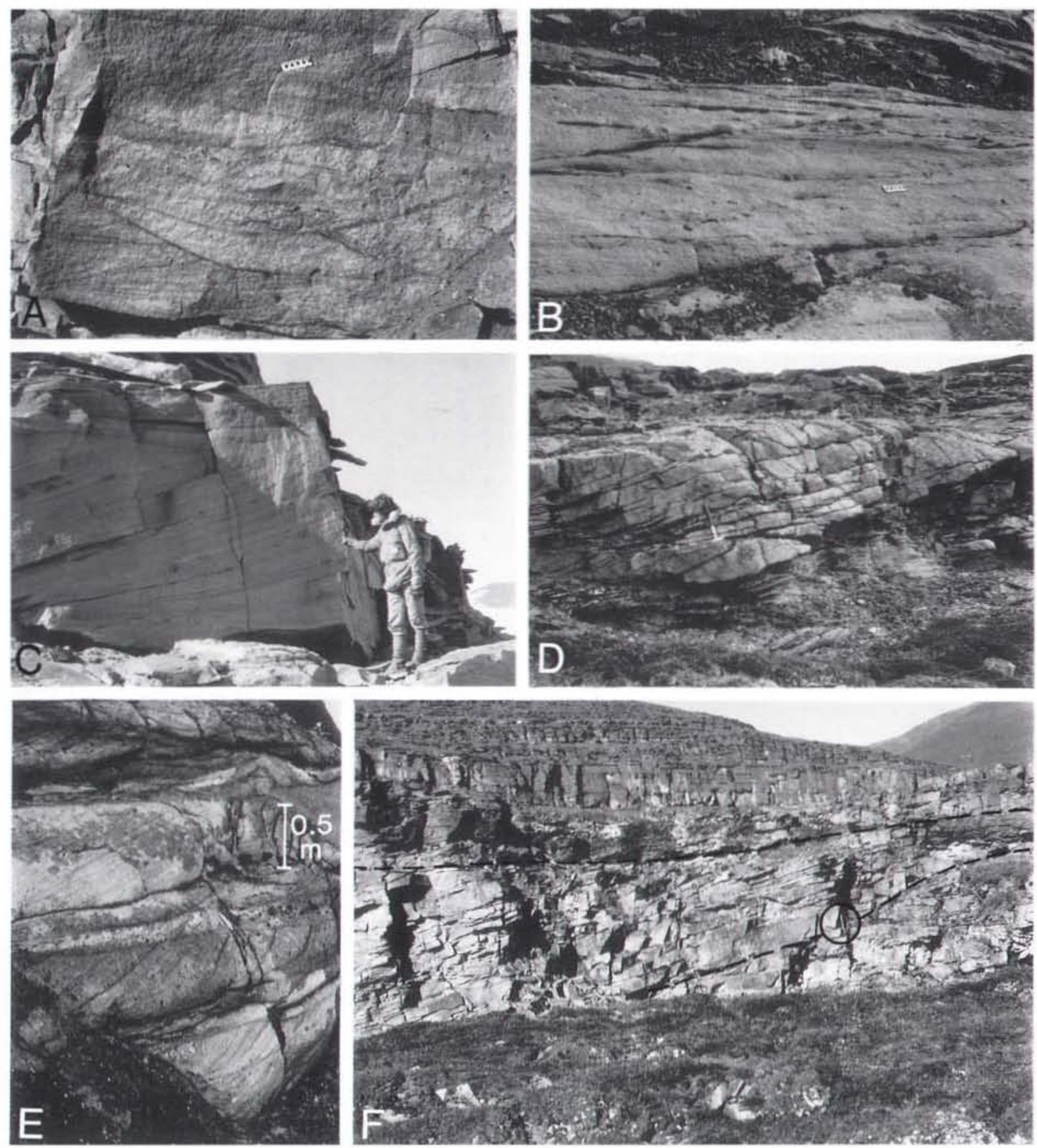

Fig. 51. Sandy braided river association. (A) Medium-scale trough cross-sets with well developed foreset lamination (Rødebjerg Formation at Rodebjerg). Ruler is $10 \mathrm{~cm}$ long. (B) Medium-scale trough cross-sets with indistinct foreset laminae (Sofia Sund Formation at Damesten), Ruler is $10 \mathrm{~cm}$. (C) Storey-scale thick planar tabular cross-set interpreted as a cross-channel bar deposit. Medium-scale trough cross-bedding, topping the tabular cross- set, indicate a palaeocurrent direction perpendicular to the tabular cross- set. (Sofia Sund Formation on western Geographical Society Ø.) (D) A large- scale trough cross-set (unit bar) associated with medium-scale trough cross- bedding (Elsa Dal Formation at Agda Dal). Hammer, $30 \mathrm{~cm}$ long for scale. (E) Medium-scale trough cross-bedding and large-scale planar wedge-shaped cross-sets. The latter exhibit periodically spaced foreset drapes deposited during low stage. (Sofia Sund Formation at Kap Graah.) (F) Inclined bedding of parallel lamination and trough cross-bedding. Flow into the exposure. The bedding is formed by lateral accretion. (Elsa Dal Formation at Wiman Bjerg.) Ringed hammer, $30 \mathrm{~cm}$ long for scale. 
A

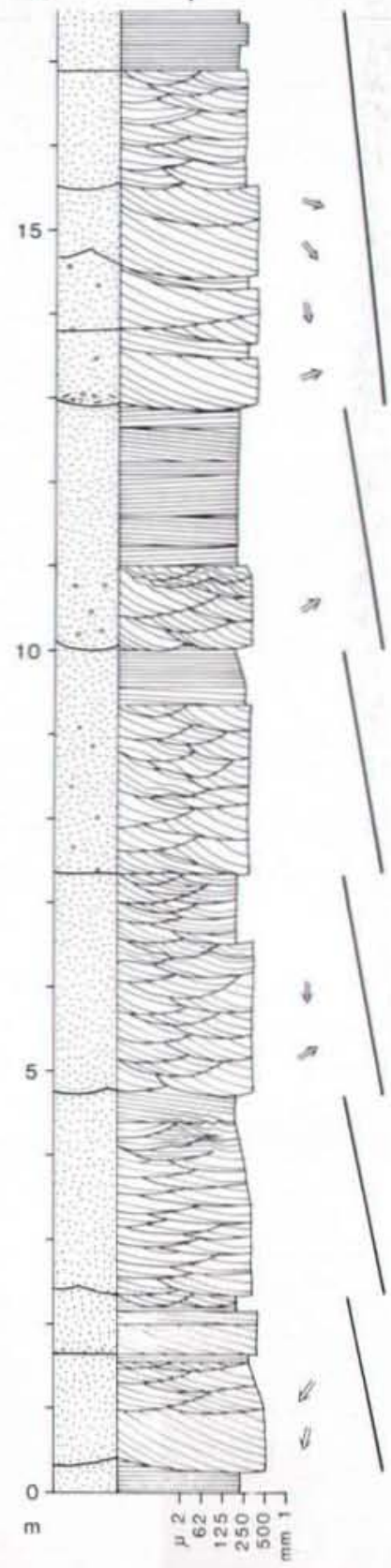

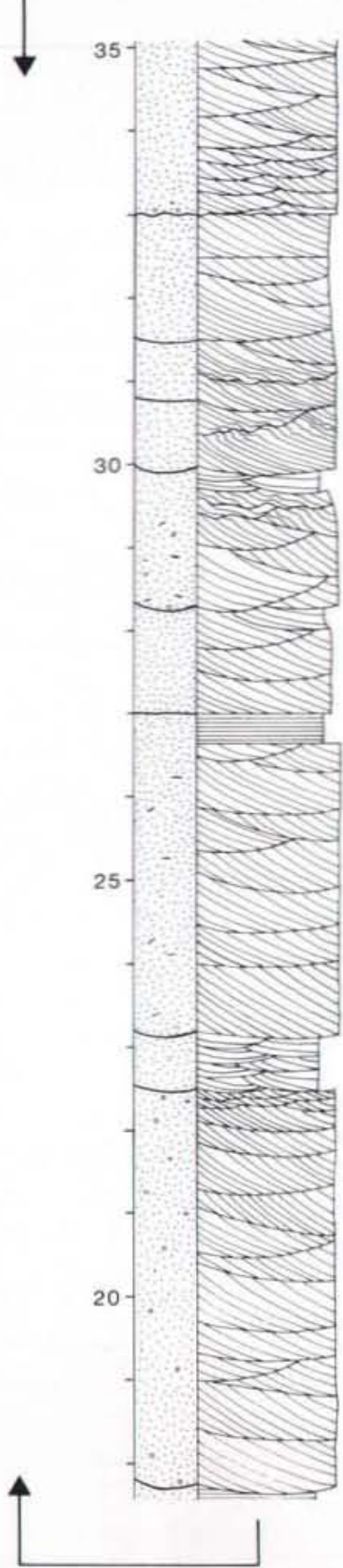

$\checkmark$

\begin{tabular}{l|l}
$\Rightarrow$ & $\mathrm{B}$
\end{tabular}

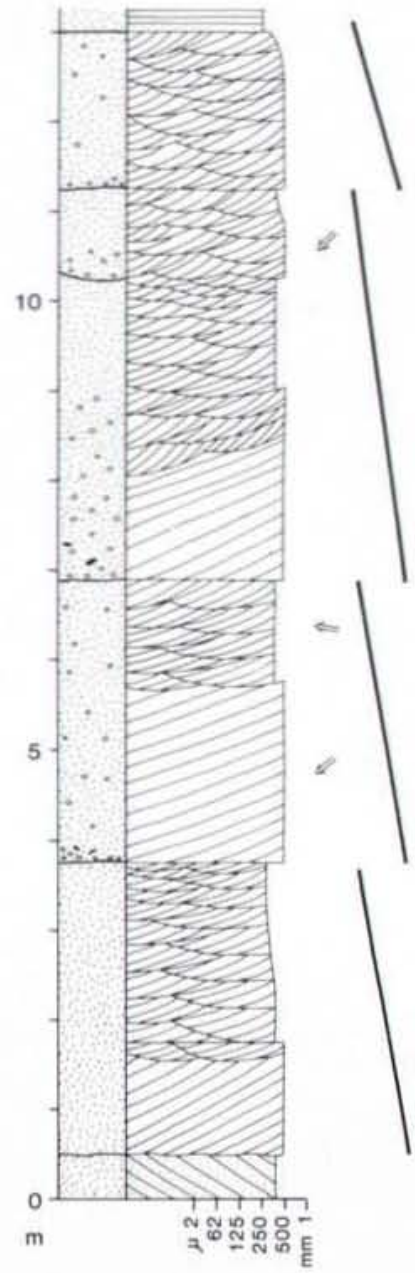

Fig. 52. Sandy braided river association. (A) Well-developed punctuated fining upward storeys (indicated by bars) interpreted in terms of compound downstream accreting braid bars. Vertical accretion deposits are probably limited to the top part of storeys. (Sofia Sund Formation east of Paralleldal, at the south coast of Gauss Halvø.) (B) Fining upward storeys with large-scale planar wedge-shaped cross-sets in the lower part of storeys (Rodsten Formation at Kap Graah), Legend: see Fig. 43. 


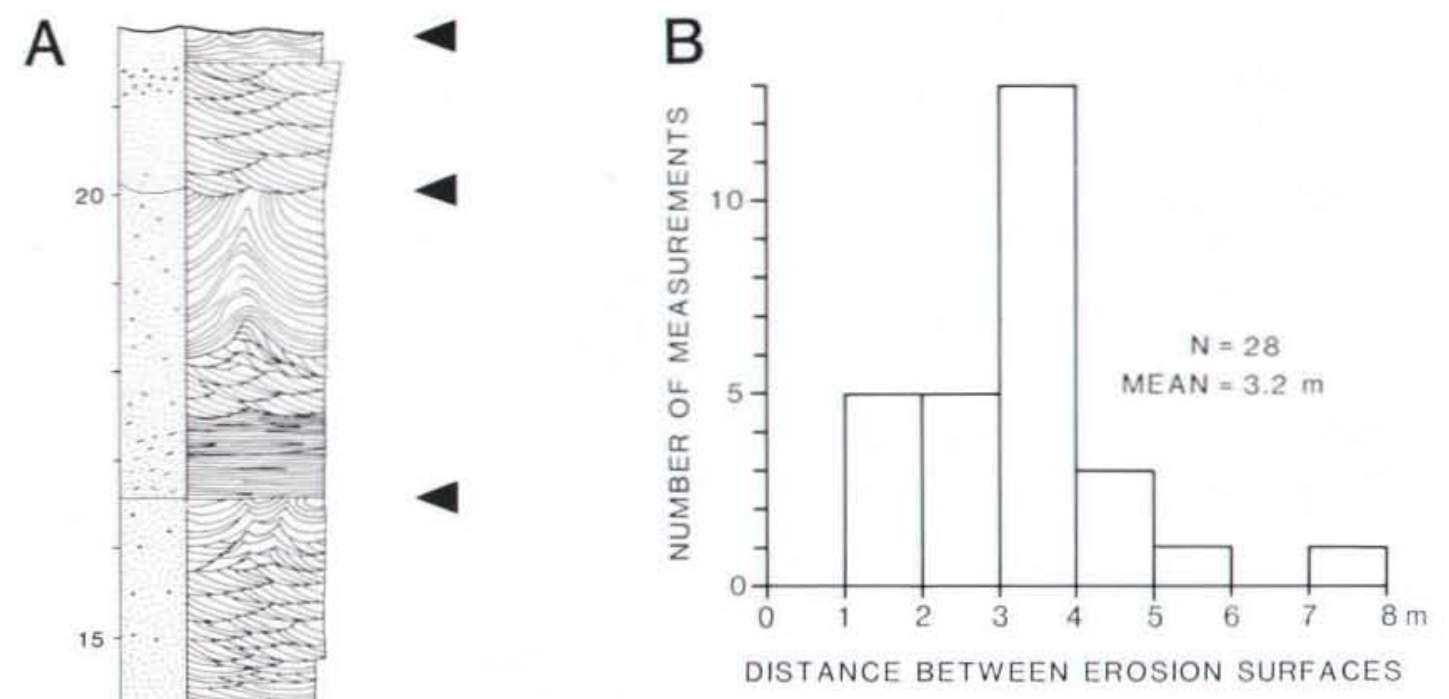

Fig. 53. Sandy braided river association (Sofia Sund Formation at Damesten in Strindberg Land). (A) Log showing a relatively finer-grained interval in the sandy braided river deposits. Notice the regular distance between successive erosion surfaces cutting through convolute bedded sandstone, indicated by triangles. For legend; see Fig. 43. (B) Histogram showing the vertical distance between successive erosion surfaces cutting convolute bedded sandstone in a c. $100 \mathrm{~m}$ thick interval of the formation, including the succession shown in (A).

odic or non-periodic bars described from modern braided rivers (Coleman, 1969; Smith, 1970, 1971, 1974; Williams, 1971; Cant, 1978; Singh et al.. 1993). The position in the lower part of storeys probably indicates a restriction of foreset bars to relatively deep channels. Reactivation surfaces and foreset drapes in large-scale crosssets indicate that the corresponding bars were not in equilibrium with low-stage flow.

Planar tabular cross-sets of storey-scale thickness (up to $2.5 \mathrm{~m}$ ) exhibiting large deviations in palaeocurrent direction from associated smaller cross-beds (Fig. 51C) are rare and interpreted as cross-channel bars comparable with those described by Cant (1978) and Cant \& Walker (1978).

Successions with apparently unsystematic distribution of grain size and sedimentary structures locally dominate (Fig. 53A) and probably represent stacking of relatively small channels without braid bar complexes. The lack of braid bars in these channels probably indicates very fluctuating dis-charge, unfavourable for braid bar development (e.g. Miall, 1985). Locally, soft sediment deformation abound in these successions (Fig. 53). The deformations may be controlled by the fluctuating discharge (cf. Doe \& Dott, 1980) or, alternatively, controlled by seismic shocks (cf. Leeder, 1987; Lang \& Fielding, 1991). 

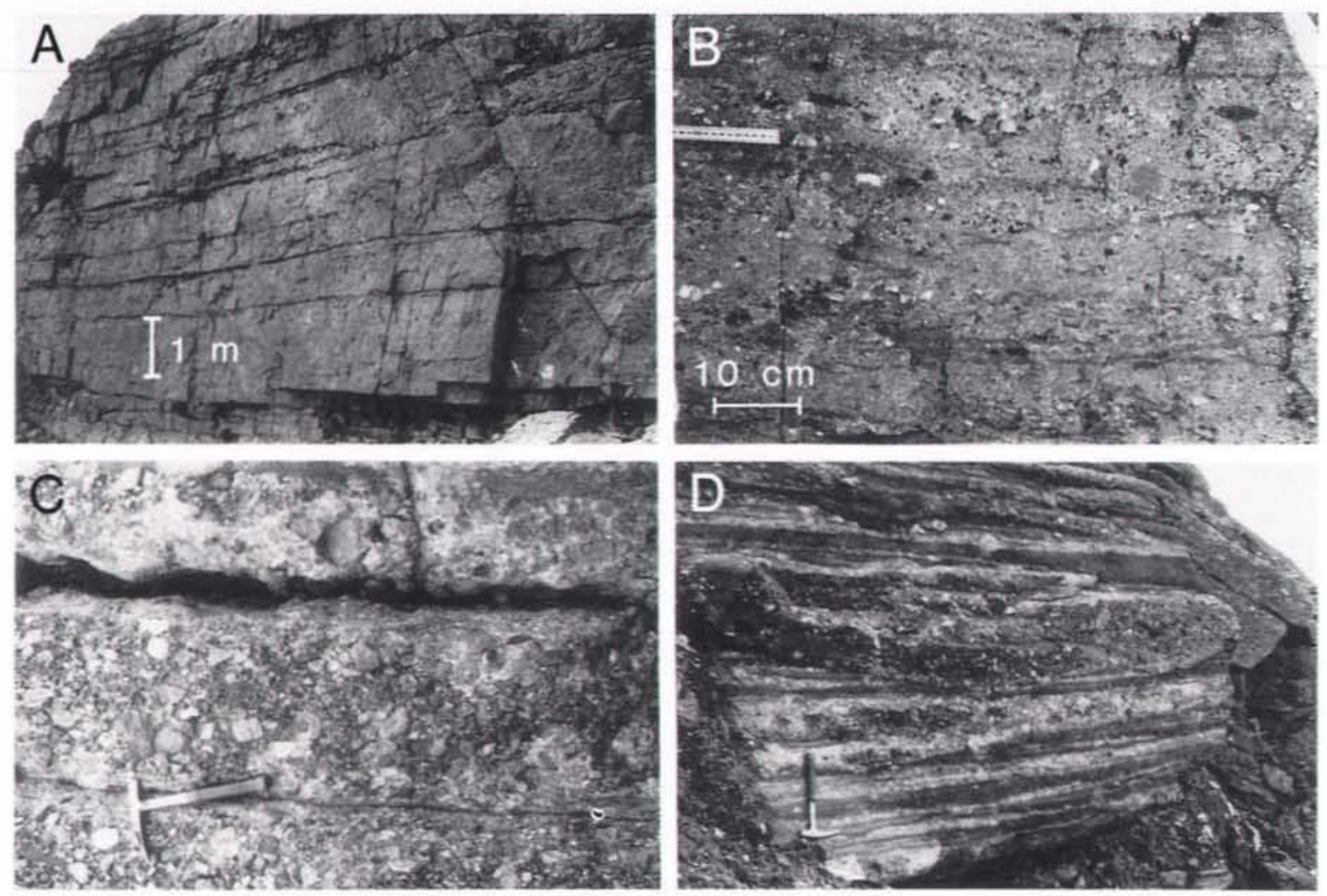

Fig. 54. Gravelly stream association; tabular sheets. (A) Tabular conglomerate sheets deposited by sheetfloods on an alluvial fan (Rødsten Formation at Kap Graah). (B) Close-up from the same locality as (A). Scour- and-fill structures in a granule and pebble conglomerate. (C) Conglomerate sheets with horizontal lamination deposited by sheetfloods on an alluvial fan. Notice the sandstone partings. Hammer, $30 \mathrm{~cm}$ long for scale. (Kap Bull Formation at the 'Moskusoksefjord inlier' north of Flett Plateau.) (D) Alternating thin beds of granule/pebble conglomerates and sandstones. interpreted as sheetflood deposits from the distal part of an alluvial fan. Hammer, $30 \mathrm{~cm}$ long for scale. Locality as (E).

\section{Gravelly stream association General characteristics}

The gravelly stream association is dominated by pebbly conglomerates with minor amounts of sandstones (Figs 54-59). The clasts are set in a matrix of grey, red or rarely green sandstone, usually weathering red. Three sediment body types occur in this association: (1) tabular conglomerate sheets, (2) channel-shaped conglomerate bodies and (3) disorganized boulder conglomerates and breccias. The association is interpreted in terms of alluvial fan and shallow braided river deposition (1), deeper braided river deposition (2), and talus and piedmont deposition (3).

\section{Previous investigations}

The gravelly stream association was classified as sample group 6 and interpreted mainly in terms of braided streams forming part of alluvial fans, comparable to pre- sent day outwash fans (Yeats \& Friend, 1978; Friend $e t$ al., 1983).

\section{Details}

The tabular conglomerate sheets are usually $0.5-1.5 \mathrm{~m}$ thick and dominated by poorly sorted conglomerates (Fig. 54). The sheets are erosionally based but downcutting is local and rarely exceeds a few centimetres (Fig. 54A). Individual thicker sheets can be traced for several tens of metres laterally when separated by sandstones. However, when sandstones are lacking individual beds may be difficult to pick out.

The most common facies in the sheets is scour-andfills of conglomerates and pebbly sandstones. Each scour is less than $20 \mathrm{~cm}$ thick and in the order of $1-2 \mathrm{~m}$ wide and long (Fig. 54B). Usually an indistinct pattern of cross-cutting scour-and-fills is observed, commonly with fining upward fills. Indistinct cross-bedding is observed locally in fills (Fig. 54B). Fining upwards of scour-and- 


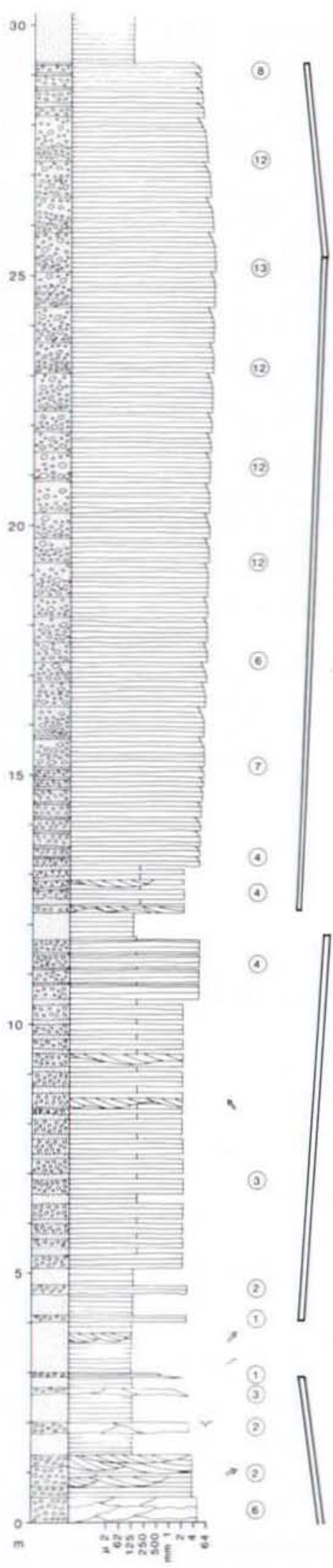

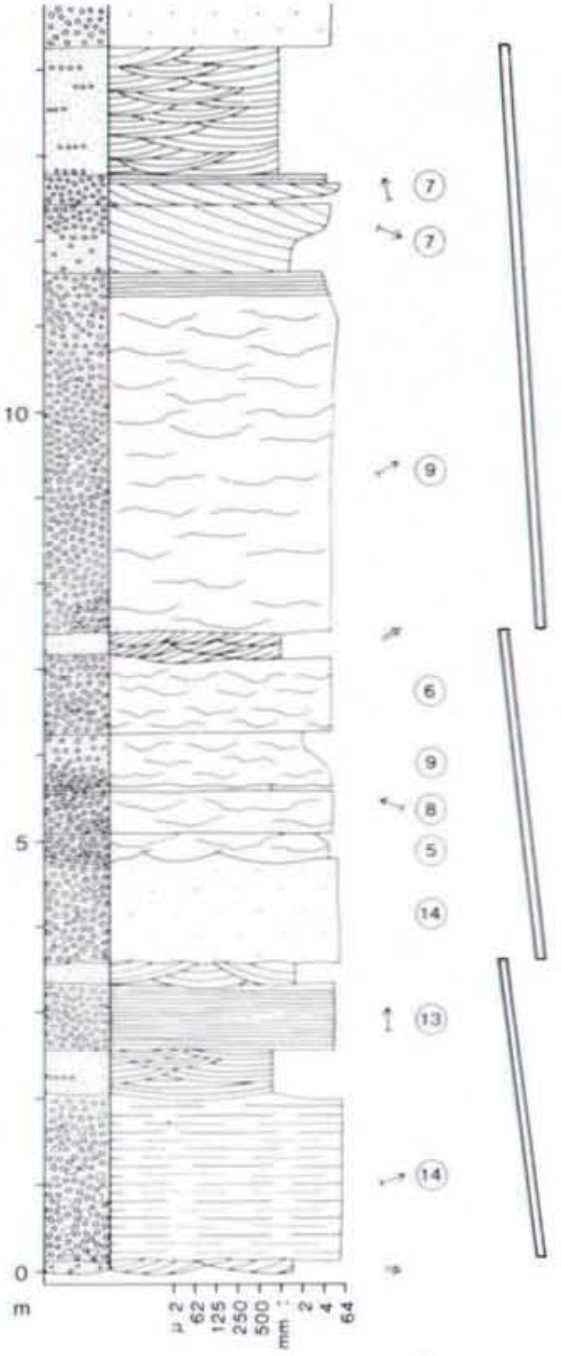

Fig. 56. Gravelly stream association; channel-shaped conglomerates. Distal gravelly braided river deposits, composed of fining upward channel-shaped storeys (shown by tilted bars). Solstrand Formation, Ankerbjergselv.

fill bedded tabular sheets from framework conglomerates to pebbly sandstones is common.

Horizontal lamination and massive bedding is another common facies in tabular sheets (Fig. 54C). Fine-grained sandstone partings a few centimetres thick are locally abundant. Horizontally laminated sheets exhibit wide variations in clast content $(10-70 \%)$ and vary from matrix supported to clast supported, and the dominant clast

Fig. 55. Gravelly stream association; tabular sheets. Alluvial fan deposits, composed of stacked coarsening and coarsening-tofining upward successions of conglomerates (indicated by tilted bars). Kap Bull Formation, SE of 'Moskusoksefjord inlier'. Legend: see Fig. 43. 
Fig. 57. Gravelly stream association: channel-shaped conglomerates. (A) Channelshaped conglomerate bodies from the Snehvide Formation at Snehvide. Notice low-stage sand drape in the lower unit. Rucksack for scale, (B) A solitary planar cross-set with sigmoidal foresets, interpreted as a delta deposit filling in a flood-eroded channel (Solstrand Formation at Solstrand). (C) Trough cross-bedded conglomerate, interpreted as crescentic gravel dune deposit (Solstrand Formation on Ella Ø). Photograph by P.-H. Larsen.
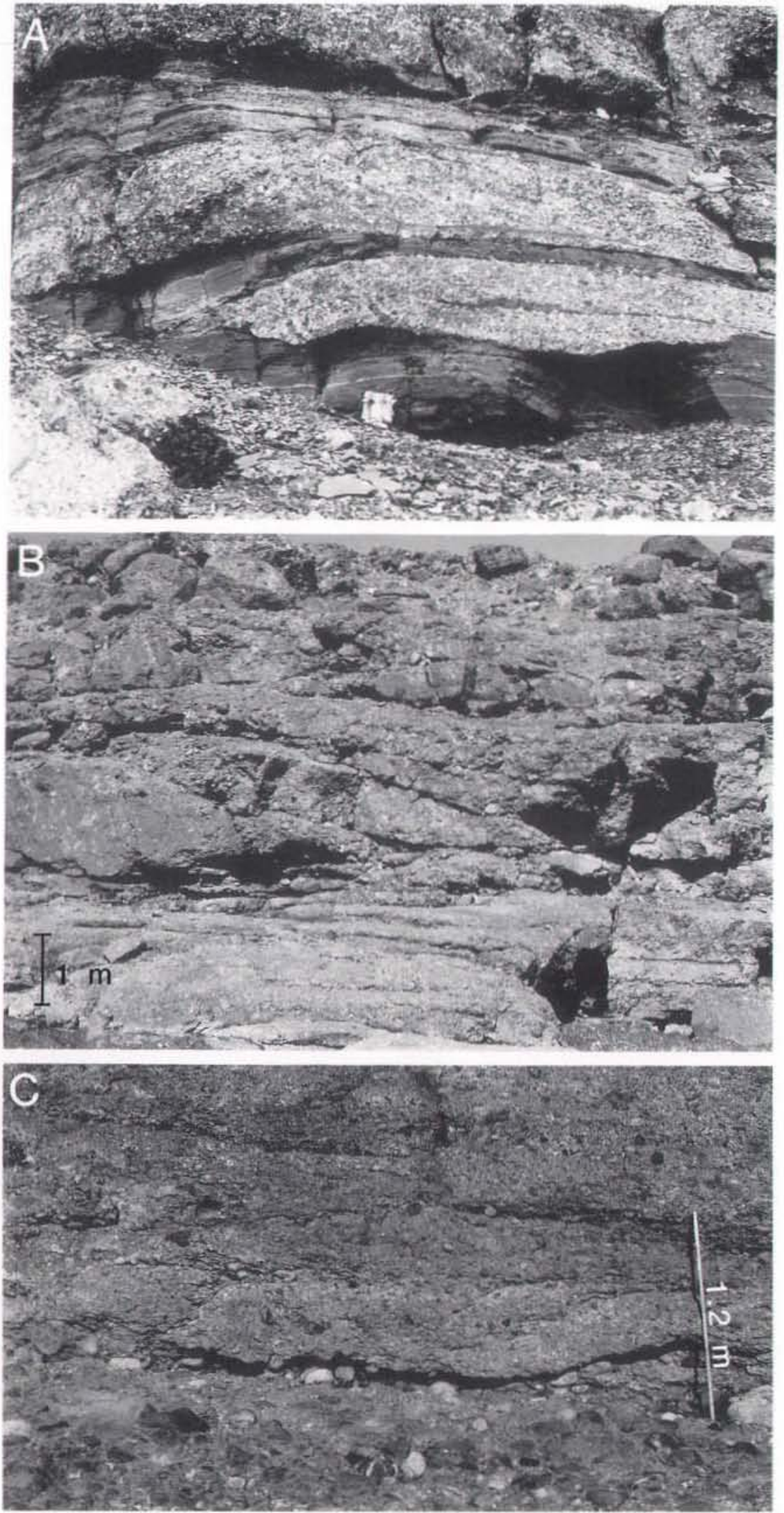


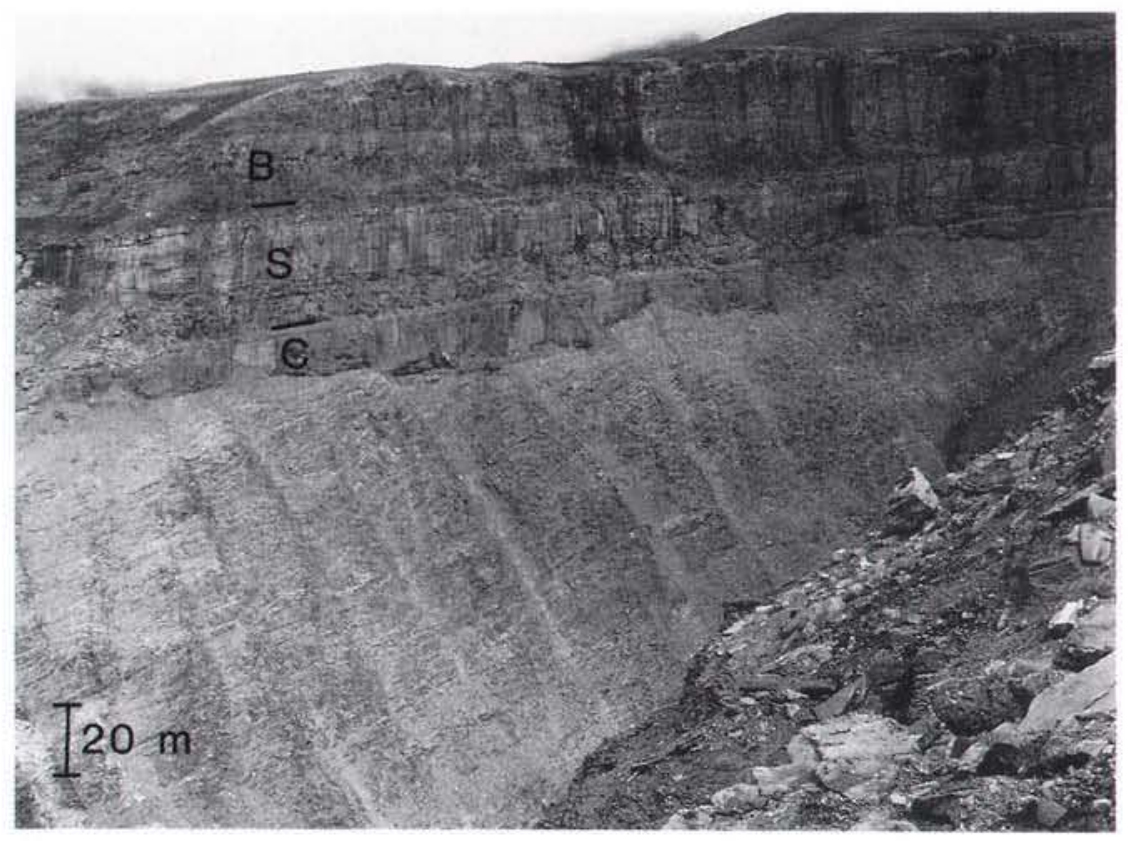

Fig. 58. Gravelly stream association; channel-shaped conglomerates. Incised valley of the Sofia Sund Formation with channel-shaped conglomerate fill (C) overlying sandstones of the Langbjerg Formation with an angular unconformity. Palaeoflow is obliquely into the cliff face. The conglomerate is succeeded by sandy braided river deposits (S) and a basaltic unit (B). Locality: Högbom Bjerg in eastern Moskusokselandet.

size varies from granules to coarse pebbles. This sheet type is commonly closely associated with scour-and-fill bedded conglomerate sheets. Massive to diffuse horizontally laminated sheets are always clast-supported and composed of more than $50 \%$ clasts, mainly in pebble size. This sheet type is commonly associated with channelshaped conglomerates. Both types of sheets locally exhibit $b$-axis imbrication with transverse $a$-axis orientation.

A third minor facies is characterized by an alternation of centimetre to decimetre thick erosively based beds of fine-grained conglomerates and horizontally laminated sandstones (Fig. 54D). The stratification in the conglomerates is horizontal and parallel low-angle inclined, and individual beds are mostly sheet-like and commonly discontinuous. Locally metre-scale wide scours, a few decimetres thick occur.

The scour-and-fill bedding resembles modern sheetflood deposits on alluvial fans described by Blair (1987b) and interpreted to form by periodic breaking of antidunes. The close association of scour-and-fill bedded sheets and tabular sheets with horizontal lamination indicates that the latter were also deposited by sheetfloods, during upper plane bed conditions. These two types of sheets are the main constituents in coarsening and coarsening-tofining upward successions, several metres to tens of metres thick (Fig. 55). This feature also suggests an alluvial fan origin (e.g. Heward, 1978; Rust, 1979; Gloppen \& Steel, 1981). The tabular massive and diffuse horizontally laminated conglomerate sheets are interpreted as longitudinal bars formed in shallow braided rivers (Rust, 1972; Smith, 1974; Boothroyd \& Ashley, 1975; Hein \& Walker, 1977; Boothroyd \& Nummedal, 1978).

The alternation of thin beds of fine-grained conglomerates and sandstones closely resemble distal sheetflood deposits described from a modern alluvial fan by Blair (1987b). This facies exclusively occurs in the finergrained part of coarsening or coarsening-to-fining upward alluvial fan successions (Fig. 55), supporting the distal fan interpretation.

Channel-shaped conglomerates generally form multistorey successions tens to hundreds of metres thick and individual storeys are $2-8 \mathrm{~m}$ in thickness (Fig. 56B). The storeys are at least tens of metres wide, usually exceeding

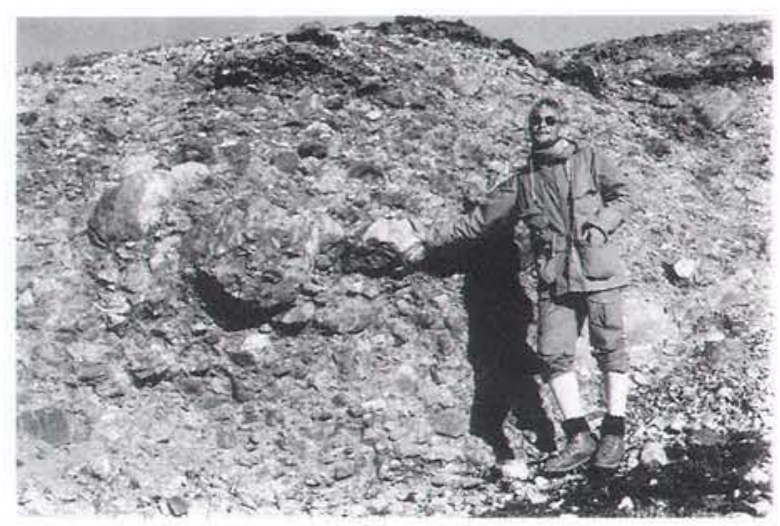

Fig. 59. Gravelly stream association; disorganized boulder conglomerate, interpreted in terms of a talus cone (Solstrand Formation at the southern mouth of Fladedal, Ymer Ø). 
the outcrops and commonly laterally amalgamated. The conglomerates are always clast-supported with rounded and sub-angular clasts and imbrication is common. The sorting varies from poor to fair. Sedimentary structures include parallel lamination, massive bedding, scour-andfills, trough cross-bedding and planar cross-bedding. Scour-and-fills in this subtype are generally thicker than in the conglomerate sheets, usually $0.5-1 \mathrm{~m}$ and closely associated with trough cross-bedding. Trough cross-bedding occurs as co-sets or as solitary sets in beds dominated by scour-and-fills. Individual sets are generally $0.5-1 \mathrm{~m}$ thick (Fig. 57C). The storeys are usually fining upwards, sometimes with trough cross-bedded sandstones in the upper part (Fig. 56B). Each storey is usually composed of stacked erosionally based non-graded or rarely fining upward bedsets, $0.5-2 \mathrm{~m}$ thick. These bedsets commonly are associated with centimetre to decimetre thick sandstone drapes (Fig 56, 57A).

The channel-shaped conglomerates obviously formed as infilling of channels, probably in braided rivers. Each fining upward storey reflects either aggradation of a channel or deposition as a braid bar complex. Massive bedding and parallel lamination in channel-shaped conglomerates are interpreted as longitudinal bar deposits in confined channels. The close association of scour-andfills and trough cross-bedding and dimensional similarities between these two facies probably reflect a similar gravel dune origin. The common stacking of conglomerate bedsets reflects infilling of channels during successive floods. The facies relations of these channel-shaped conglomerates correspond to the distal gravelly braided river model of Rust $(1978,1979)$.

Locally up to $6 \mathrm{~m}$ thick channel-shaped conglomerates dominated by solitary planar cross-sets occur, closely associated with tabular massive conglomerate sheets. Such cross-sets may occasionally exhibit sigmoidal shapes of foresets (Fig. 57B) and commonly grade laterally downstream into conglomerate sheets.

The solitary channel-filling cross-sets are interpreted as formed in proximal gravelly braided rivers in response to major floods. In the Devonian, hill slopes were probably unprotected by vegetation resulting in deeper and more frequent floods than in modern braided rivers (Schumm, 1968; Rust, 1979). According to Ramos \& Sopena (1983) and Massari (1983), flood-scoured pools in the bed surface may be filled up by gravelly deltas. An interbedding of tabular sheets and planar cross-beds is therefore expected in ancient proximal braided river deposits (Rust, 1979). The occasional sigmoidal shape and downstream transition into tabular sheets suggest rapid cutting of channels and progradation of deltas into the channels during peak and falling flow, followed by verti- cal accretion on longitudinal bars during normal flood conditions.

Channel-shaped conglomerates is the most common sediment type above angular unconformities. The conglomerates usually fill in incised valleys cut into a rising substrate (Fig. 58).

The poorly sorted and disorganized boulder conglomerates and breccias are characterized by the absence of bedding and sedimentary structures (Fig. 59). These deposits always overlie the pre-Devonian (mainly limestone/dolostone) basement and commonly occurs as infilling of irregular or channel-shaped topography in the limestone/dolostone surfaces. Commonly an upward gradual transition occurs from massive carbonate bedrock, to cracked carbonate with pebbly and sandy fill of cracks, to breccia. The sediments are interpreted in terms of steep talus cones and infilling of mountain gullies, and as piedmont mantles (cf. Denny, 1967; Williams, 1970).

\section{Lacustrine association General characteristics}

The lacustrine association is composed of mudshales. silty mudstones, siltstones, very fine-grained sandstones and limestones (Figs 60-63). The sediments are characterized by the absence of large-scale sedimentary structures. The association can be divided into three subtypes: (1) perennial lacustrine deposits consisting of black bituminous shales and limestones and non-bituminous mudstones; (2) ephemeral or marginal lacustrine deposits characterized by laminated siltstones and sandstones; and (3) palustrine deposits composed of crudely laminar limestone with wave cross-laminated interbeds.

\section{Previous investigations}

Thick successions of lacustrine deposits were described by Alexander-Marrack \& Friend (1976) from the Vilddal Group in the Kap Franklin area outside the main study area of the present investigation. They were composed of grey mudstones and siltstones and rare black shales, assigned to sample groups $4 \mathrm{~B}, 4 \mathrm{C}, 4 \mathrm{D}$ and $4 \mathrm{G}$. Sample group $4 \mathrm{C}$ was interpreted as deposited in the deepest part of a lake, composed of the finer-grained sediments. Sample group $4 \mathrm{G}$ was deposited in the marginal lacustrine environment and seems to resemble the laminated siltstone and sandstone facies described below. The two other sample groups were interpreted as intermediate types. Nicholson \& Friend (1976) also interpreted sample group $4 \mathrm{C}$ in their successions (mainly in the Wimans Bjerg Formation) as partly lacustrine. In accordance with the present author the laminated siltstones and 

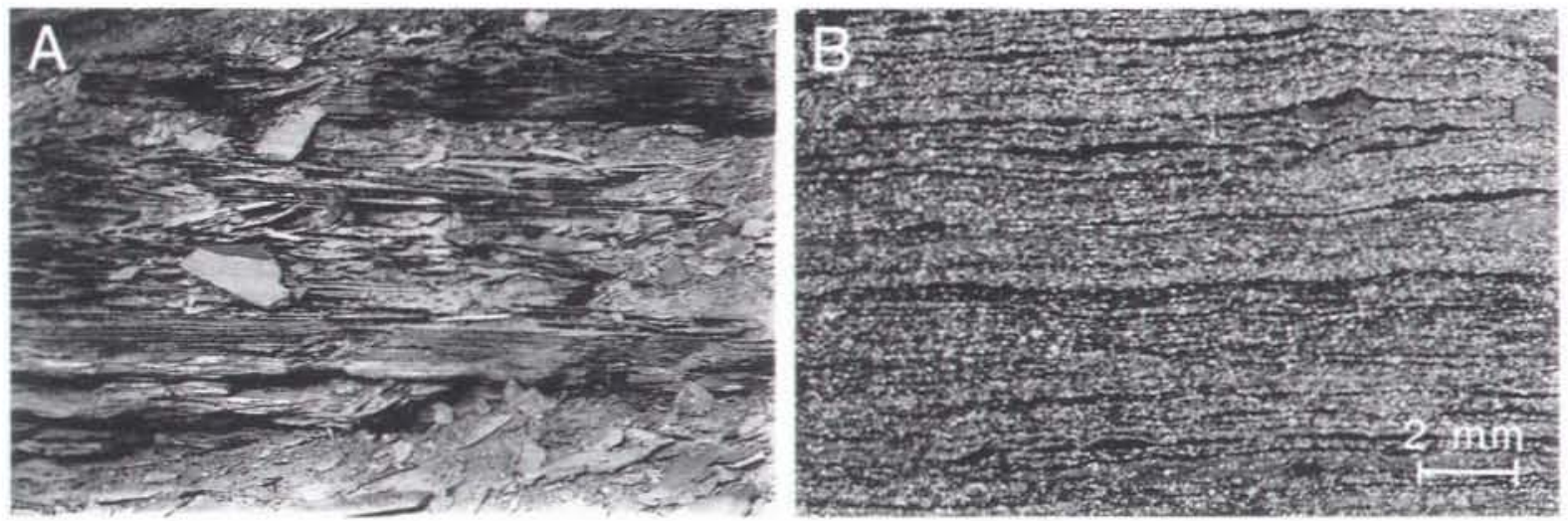

Fig. 60. Lacustrine association; perennial lacustrine deposits. (A) Black shale, laminated on a submillimetre scale. Vergys Formation near Forbindelsesdal in Moskusokselandet. (B) Thin section of the black shale from (A) exhibiting couplets of organic-rich (dark) and organic-poor laminae, interpreted as reflecting seasonal variations in algae productivity and in discharge of the inflowing rivers.

sandstones were interpreted as ephemeral lake deposits. The interbedded brecciated to massive mudstones were interpreted as playa mud flat deposits (assigned to the flood basin association by the present author). Black shales were also reported by Nicholson \& Friend (1976), however, without environmental interpretation.

\section{Details}

The perennial lacustrine deposits usually occur in units $0.5-6 \mathrm{~m}$ thick. The dominant facies is generally black bituminous clay- and mudshales laminated on a millimetre to submillimetre scale (Figs 60A, B). Laminae are even, continuous and composed of alternations (couplets) of organic-rich and organic-poor quartz claystone or mudstone (Fig. 60B). The content of silt-size mica is low to moderately high and concentrated in the organic-poor laminae. Locally slightly thicker laminae and lenses of quartz siltstone occur. These lenses are up to a few millimetres thick, $10-50 \mathrm{~mm}$ long, are isolated or connected by stringers of quartz silt a few grains thick. Occasionally low-angle cross-lamination occurs in the lenses. Locally carbonate-rich laminae also occur and triplets may be developed. Associated with the black shales are shaly and massive black bituminous limestones. These sediments are transitional to the shales and the distinction between carbonate-rich shales and shaly limestone is arbitrary. The carbonate always occurs as micritic calcite deposits, usually lacking sedimentary structures such as lamination. The shales have a total organic carbon (TOC) content in the range of $0.5-13 \%$ and a total sulphur (TS) content in the range of < 0.1-0.5\% (Christiansen et al., 1990). The limestones have TOC values less than $1 \%$. The organic matter is dominated by amorphous kerogen and sporomorphs forming $80-100 \%$. Locally grey, black or green silty mudstones occur in units up to a few metres thick. These deposits are horizontally laminated to massive and the organic carbon content is generally less than $0.1 \%$. They may be associated with black shales.

The black shales and limestones are interpreted as hypolimnic sediments from thermally stratified perennial lakes. The organic content of the shales and the fact that they rarely contain fossils and lack bioturbation are indicative of anoxic bottom waters. The low values of TS distinguish the studied material from marine shales and support a fresh-water depositional environment (e.g. Berner \& Raiswell, 1984). Very limited supply of river transported material into the hypolimnic part of lakes is reflected in those shales and limestones with a dominance of amorphous kerogen, which is regarded as autochthonous The couplets (and triplets) are interpreted to reflect seasonal variations in algal productivity, and in discharge of the inflowing rivers (cf. Donovan, 1980; Halfman \& Johnson, 1988). The detrital quartz siltstone lenses resemble type MI of de Raaf et al. (1977) attributed to ripple formation due to weak wave agitation. Generally, however, the lake bottoms appear to be situated below wave base. The silty mudstones are interpreted as perennial lake sediments, deposited at relatively deep but epilimnic parts of lakes closer to the lake margins.

The ephemeral or marginal lacustrine deposits are composed of stacked $0.5-30 \mathrm{~cm}$ thick sharp based and commonly erosive siltstone and sandstone beds (Fig. 61). The sediments are grey, red or green and dominated by parallel laminated and wave cross-laminated coarse siltstones and very fine-grained sandstones (Figs 61B, C, 62). Convolute bedding is locally common (Figs 61A, $62 \mathrm{~B})$. Individual beds commonly fine upwards from parallel lamination to cross-lamination or form part of fin- 

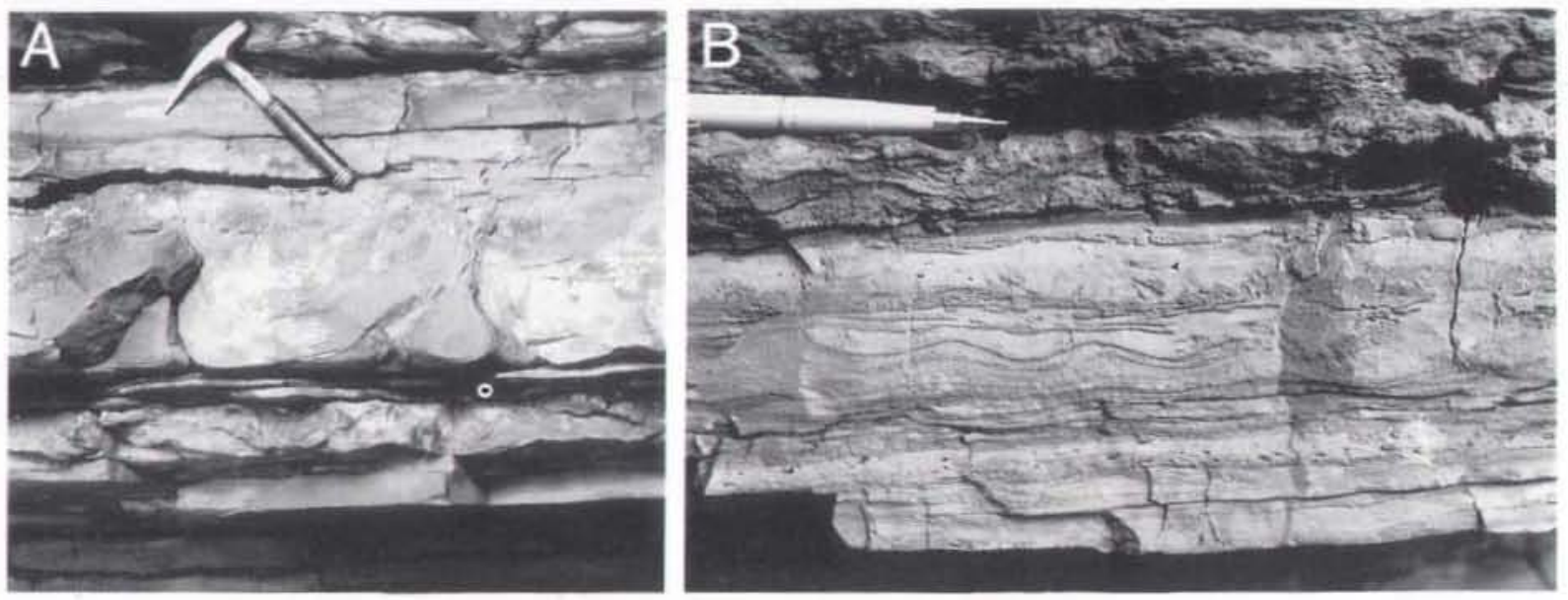

C

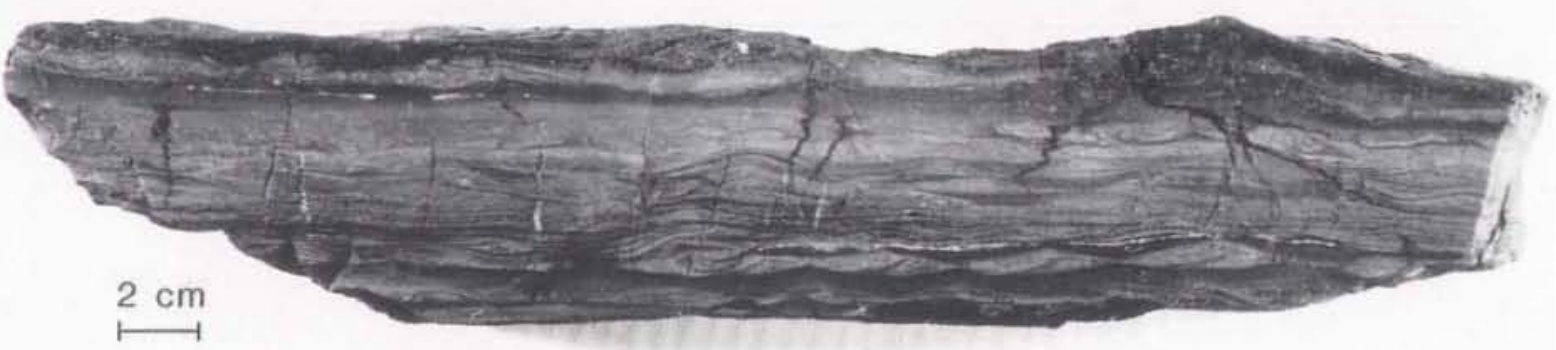

Fig. 61 Lacustrine association; ephemeral and marginal lacustrine deposits. (A) Laminated siltstones and sandstones exhibiting convolute bedding. The sediments were deposited in shallow water, probably close to the lake shoreline. (Vergys Formation near Forbindelsesdal.) A $30 \mathrm{~cm}$ long hammer is shown for scale. (B) Laminated siltstones. Several beds are stacked to form a $c .10 \mathrm{~cm}$ thick composite bedset. Notice the presence of well- developed wave ripple formsets. The sediments were deposited by repeated expansions and contractions of an ephemeral lake. Wimans Bjerg Formation at Stensiö Bjerg. (C) Stacked laminated siltstones, in the lower part developed as wavy bedding. The cross-lamination exhibits typical features of wave ripple lamination. Notice the presence of desiccation cracks commencing from the top of several beds, indicating repeated subaerial exposure. (Hand specimen from Wimans Bjerg Formation at Stensiö Bjerg.)

ing-upward couplets. The upper part of such beds or couplets is commonly formed by a parallel laminated silty drape with common desiccation cracks (Fig. 61C).

The sedimentary features of the laminated siltstones and sandstones indicate deposition in shallow water experiencing rapid fluctuations. Emergence of the bed surface occurred frequently as evidenced by desiccation cracks. Convolute bedding probably formed due to liquefaction (Doe \& Dott, 1980; Reineck \& Singh, 1980; Allen, 1984) associated with rapid lake level fluctuations. The wave cross-lamination exhibits many similarities with the type M2 of de Raaf et al. (1977) formed by moderate to high energy wave agitation. The finingupward sequences and couplets resemble small-scale sequences described by de Raaf et al. (1977) and interpreted as formed during decreasing energy conditions.
These sequences and couplets probably formed in response to heavy rainstorms and rapid expansion of lakes (e.g. Demicco \& Kordesh, 1986). The common occurrence of desiccation cracks on top of sequences indicates subsequent lake contraction following the expansion.

The laminated siltstones and sandstones usually occur closely associated with either the lacustrine black shales and limestones, or brecciated mudstones of the flood basin association (Fig. 62B). When the laminated siltstones and sandstones are associated with the black shales and limestones they probably formed as shoreline deposits of perennial lakes. In contrast, when associated with brecciated mudstones they probably formed during expansion of ephemeral lakes on playa mud flats.

The palustrine deposits were only observed at one stratigraphic level within the Wimans Bjerg Formation, 


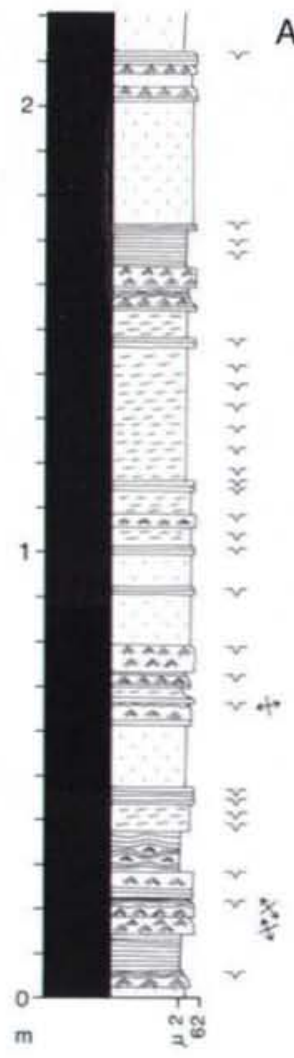

A

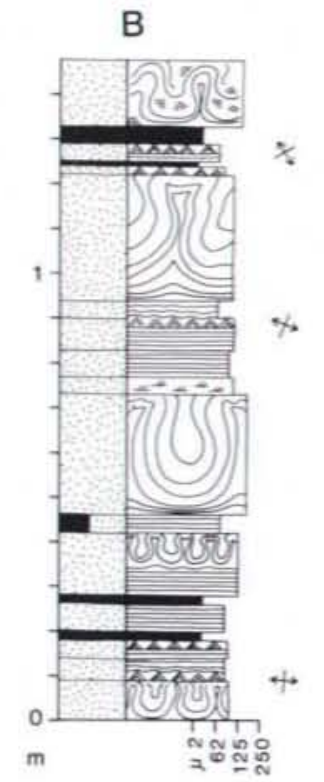

Fig. 62. Lacustrine association; ephemeral and marginal lacustrine deposits. (A) Laminated siltstones of lacustrine origin associated with brecciated and apparently massive mudstones of flood basin origin. The laminated siltstones were deposited in ephemeral lakes, whereas the brecciated/massive mudstones were deposited on subaerial mud flats (Wimans Bjerg Formation at Stensiö Bjerg). (B) Laminated sandstones and siltstones. Immediately below these deposits a unit of black shales (Figs $61 \mathrm{~A}, \mathrm{~B}$ ) is present. The sandstones and siltstones were deposited near the shoreline of a perennial lake, whereas the black shales represent the deeper part of the lake. (Vergys Formation near Forbindelsesdal.) Legend: see Fig. 43.

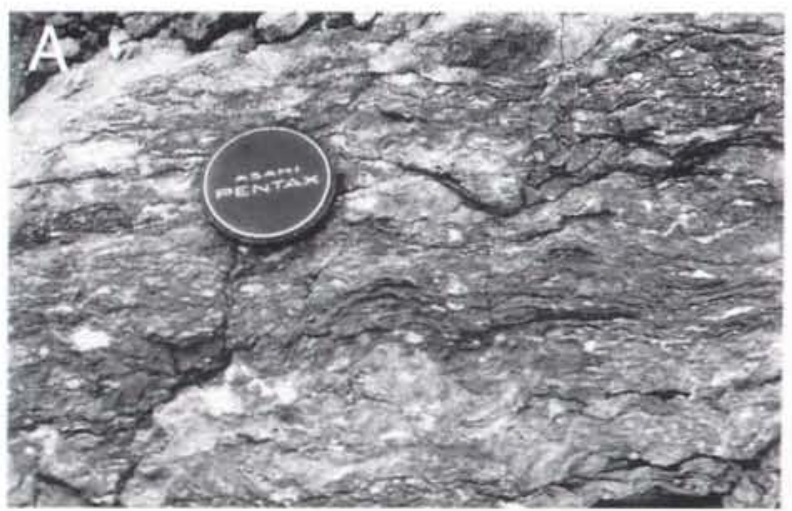

close to the basin margin at the time of deposition. A $c$. $10 \mathrm{~m}$ thick succession of interbedded crudely laminar limestone (dominant) and cross-laminated siltstone and sandstone was observed (Fig. 63). The crudely laminar limestone occurs in decimetre thick beds composed of carbonate and carbonate-cemented mudstone laminae, which are millimetre thick, very irregular and poorly defined. Millimetre-centimetre size carbonate nodules abound (Fig. 63A) and locally the limestones form tepees $20-50 \mathrm{~cm}$ high (Fig. 63B). The siltstone and sandstone beds are a few centimetres thick and are dominated by wave ripple cross-lamination with abundant desiccation cracks.

The crudely laminar limestones, carbonate nodules and tepees are interpreted as very mature calcretes developed in a palustrine environment (cf. Allen, 1986; Wright et al., 1988; Kendall \& Warren, 1987). The interbedding with the wave ripple cross-laminated deposits, the location at the basin margin, and the absence of alluvial clastic sediments collectively imply that the depositional site formed an elevated area only periodically flooded by lake waters.

\section{Acknowledgements}

The project was supported by grants from the Carlsberg Foundation, to which I wish to express my sincere gratitude. Thanks are also directed to the Geological Survey of Greenland which initiated the project, supported me by a grant and provided technical assistance and helicopter support.

I am grateful to Poul-Henrik Larsen with whom I had a close and fruitful cooperation which greatly enhanced the quality of the present report. Thanks are due to my field assistants Jørgen Bojesen-Kofoed, Hans Jepsen, Henrik Nøhr-Hansen and Uffe Wilken for cheerful company. Discussions with colleagues at the Geological Survey of Greenland contributed to the development of the ideas presented in this paper. Vibber Hermansen, Anne-Lene Felland, Annette Printz and Else Palner Clausen

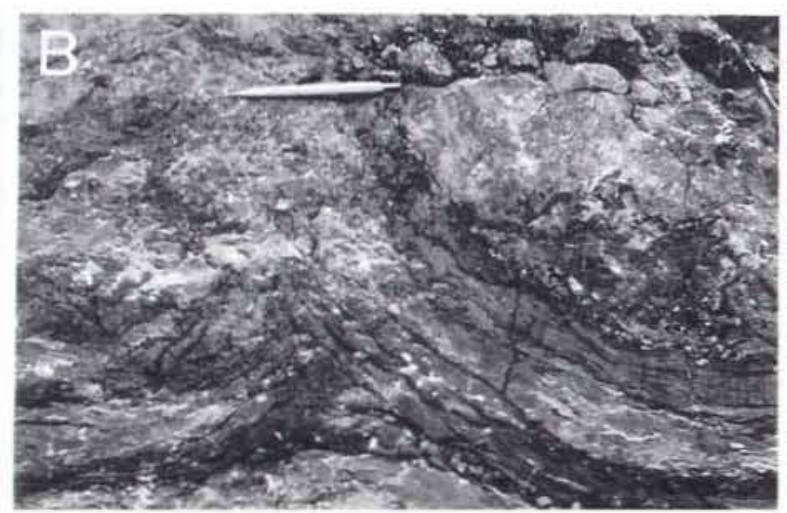

Fig. 63. Lacustrine association; palustrine deposits. (A) Crudely laminar limestone. Lens cap is $5.5 \mathrm{~cm}$. (B) Limestone tepee. Pencil for scale $(14 \mathrm{~cm})$. Wimans Bjerg Formation at Obrutschew Bjerg. 
assisted in typing the manuscript. Jette Halskov, Bodil Sikker Hansen, John Boserup, Vibeke Knudsen, Steen Skytte and Jakob Lautrup with assistants completed the figures. Svend Erik Bendix-Almgreen, Hans Christian Larsen and Finn Surlyk kindly recommended the project to the Carlsberg Foundation. I am grateful to Lars B. Clemmensen, Peter F. Friend and Martin Sønderholm for thorough reviews of the manuscript.

\section{References}

Ahlbrandt, T. S. \& Fryberger, S. G. 1981: Sedimentary features and significance of interdune deposits. In Ethridge, F. G. \& Flores, R. M. (ed.) Recent and ancient nonmarine depositional environments, models for exploration. Spec. Publ. Soc. Econ. Paleont. Miner. 31, 293-314.

Alexander-Marrack, P. D. \& Friend, P. F. 1976: Devonian sediments of East Greenland III. The Eastern sequence, Vilddal Supergroup and part of the Kap Kolthoff Supergroup. Meddr Gronland 206(3), 122 pp.

Allen, J. R. L. 1965: The sedimentation and palaeogeography of the Old Red Sandstone of Anglesey, North Wales. Yorks. Geol. Soc. Proc. 35, 139-185.

Allen, J. R. L. 1970: Studies in fluviatile sedimentation: a comparison of fining upwards cyclothems, with special reference to coarse-member composition and interpretation. $J$. sedim. Petrol. 40, 298-323.

Allen, J. R. L. 1974: Studies in fluvial sedimentation: implications of pedogenic carbonate units, Lower Old Red Sandstone, Anglo-Welsh outcrop. Geol. J. 9, 181-208.

Allen, J. R. L. 1983: Studies in fluviatile sedimentation: bars, bar-complexes and sandstone sheets (low-sinuosity braided streams) in the Brownstones (L. Devonian), Welsh Borders. Sediment. Geol. 33, 237-293.

Allen, J. R. L. 1984: Sedimentary structures, their character and physical basis. Developments in Sedimentology 30, 1256 pp. Amsterdam: Elsevier.

Allen, J. R. L. 1986: Pedogenic calcretes in the Old Red Sandstone facies (Late Silurian - Early Carboniferous) and the Anglo-Welsh area, southern Britain. Chapter 2. In Wright, V. P. (ed.) Paleosols, their recognition and interpretation, 58-86. Oxford: Blackwell Scientific Publ.

Allen, P. A. \& Collinson, J. D. 1986: Lakes In Reading, H. G. (ed.) Sedimentary environments and facies, 63-94. Oxford: Blackwell Scientific Publ.

Beerbower, J. R. 1964: Cyclothems and cyclic depositional mechanics in alluvial plain sedimentation. Bull. Kansas geol. Surv. 169, 31-42.

Bendix-Almgreen, S. E., Clack, J. A. \& Olsen, H. 1988: Upper Devonian and Upper Permian vertebrates collected in 1987 around Kejser Franz Joseph Fjord, central East Greenland. Rapp. Grønlands geol. Unders. 140, 95-102.

Bendix-Almgreen, S. E., Clack, J. A. \& Olsen, H. 1990: Upper Devonian tetrapod palaeoecology in the light of new discoveries in East Greenland. Terra Nova 2, 131-137.

Berger, A. L. 1977: Support for the astronomical theory of climatic change. Nature, Lond. 269, 44-45.

Berger, A., Loutre, M. F. \& Dehant, V. 1989: Astronomical frequences for pre-Quaternary palaeoclimate studies. Terra Nova 1, $474-479$.

Berner, R. A. \& Raiswell, R. 1984: C/S method for distinguishing freshwater from marine sedimentary rocks. Geology 12, 365-368.

Beutner, E. C., Fleuckinger, L. A. \& Gard, T. M. 1967: Bedding geometry in a Pennsylvanian channel sandstone. Bull. geol. Soc. Am. 78, 911-916.

Blair, T. C. 1987a: Tectonic and hydrolic controls on cyclic alluvial fan, fluvial, and lacustrine rift-basin sedimentation, Jurassic - lowermost Cretaceous Todos Santos Formation, Chiapas, Mexico. J. sedim. Petrol. 57, 845-862.

Blair, T. C. 1987b: Sedimentary processes, vertical stratification sequences, and geomorphology of the Roaring River alluvial fan, Rocky Mountain National Park, Colorado. J. sedim. Petrol. 57, 1-18.

Blakey, R. C. \& Middleton, O. T. 1983: Permian shoreline eolian complex in central Arizona. Dune changes in response to cyclic sealevel changes. In Brookfield, M. E. \& Ahlbrandt, T. S. (ed.) Eolian sediments and processes. Developments in Sedimentology 38, 551-581. Amsterdam: Elsevier.

Bluck, B. J. 1971: Sedimentation in the meandering River Endrick. Scott. J. Geol. 7, 93-138.

Boothroyd, J. C. \& Ashley, G. M. 1975: Process, bar morphology and sedimentary structures on braided outwash fans, north-eastern Gulf of Alaska. In Jopling, A. V. \& McDonald, B. C. (ed.) Glaciofluvial and glaciolacustrine sedimentation. Spec. Publ. Soc. econ. Paleont. Miner. 23, 193-222.

Boothroyd, J. C. \& Nummedal, D. 1978: Proglacial braided outwash: a model for humid alluvial fan deposits. In Miall, A. D. (ed) Fluvial sedimentology. Mem. Can. Petrol. Geol. 5, 641-668.

Bridge, J. S. 1975: Computer simulation of sedimentation in meandering streams. Sedimentology 22, 3-43.

Bridge, J. S. 1984: Large-scale facies sequences in alluvial overbank environments. J. sedim. Petrol. 54, 583-588.

Bridge, J. S. \& Diemer, J. A. 1983: Quantitative interpretation of an evolving ancient river system. Sedimentology 30, 599623.

Bridge, J. S. \& Leeder, M. R. 1979: A simulation model of alluvial stratigraphy. Sedimentology 26, 617-644.

Bridges, E. M. 1970: World soils, 89 pp. Cambridge University Press.

Bristow, C. S. 1987: Brahmaputra River: channel migration and deposition. In Ethridge, F. G., Flores, R. M. \& Harvey, M. D. (ed.) Recent developments in fluvial sedimentology. Spec. Publ. Soc. Econ. Paleont. Miner. 39, 63-74. 
Brookfield, M.E. 1977: The origin of bounding surfaces in ancient aeolian sandstones. Sedimentology 24, 303-332.

Brown, L. F., Jr. \& Fisher, W. L. 1977: Seismic-stratigraphic interpretation of depositional systems: examples from Brazilian rift and pull-apart basins. In Payton, C. E. (ed.) Seismic stratigraphy-applications to hydrocarbon exploration. Am. Assoc. Petrol. Geol. Mem. 26, 213-248.

Bütler, H. 1935a: Die Mächtigkeit der kaledonischen Molasse in Ostgrönland. Mitt. Naturforsch. Gesellschaft Schaffhausen 12, 17-33.

Bütler, H. 1935b: Some new investigations of the Devonian stratigraphy and tectonics of East Greenland. Meddr Grønland 103(2), $35 \mathrm{pp}$.

Bütler, H. 1954: Die stratigraphische Gliederung der mitteldevonischen Serien im Gebiet von Kap Franklin in ZentralOstgrönland. Meddr Grønland 116(7), 126 pp.

Bütler, H. 1955: Das variscisch gefaltete Devon zwischen Dusén Fjord und Kongeborgen in Zentral-Ostgrönland. Meddr Grønland 155(1), 131 pp.

Bütler, H. 1957: Beobachtungen an der Hauptbruchzone der Küste von Zentral-Ostgrönland. Meddr Grønland 160(1), 79 pp.

Bütler, H. 1959: Das Old Red-Gebiet am Moskosoksefjord. Attempt at a correlation of the series of various Devonian areas in Central East Greenland. Meddr Gronland 160(5), 88 pp.

Bütler, H. 1961: Devonian deposits of central East Greenland. In Raasch, G. O. (ed.) Geology of the Arctic 1, 188-196. Toronto U.P.

Cant, D. J. 1978: Bedforms and bar types in the South Saskatchewan River. J. sedim. Petrol. 48, 1321-1330.

Cant, D. J. \& Walker, R. G. 1978: Fluvial processes and facies sequences in the sandy braided South Saskatchewan River, Canada. Sedimentology 25, 625-648.

Caputo, M. V. \& Crowell, J. C. 1985: Migration of glacial centers across Gondwana during Paleozoic era. Bull. geol. Soc. Am. 96, 1020-1036.

Christiansen, F. G., Olsen, H., Piasecki, S. \& Stemmerik, L. 1990: Organic geochemistry of Upper Palaeozoic lacustrine shales in the East Greenland basin. In Durand, B. \& Behar, F. (ed.) Advances in organic geochemistry 1989, Part I. Organic Geochemistry 16, 287-294.

Clack, J. A. 1989: Discovery of the earliest known tetrapod stapes. Nature, Lond. 342, 425-427.

Clemmensen, L. B. 1986: Storm-generated eolian sand shadows and their sedimentary structures, Vejers Strand, Denmark. J. sedim. Petrol. 56, 520-527.

Clemmensen, L. B. 1991: Æolisk arkitektur og aflejringsdynamik. En undersøgelse af ni æoliske aflejringssystemer (Prækambrium-Recent) fra den nordatlantiske region. Dr. Phil. thesis, $39 \mathrm{pp}$. University of Copenhagen.

Clemmensen, L. B. \& Abrahamsen, K. 1983: Aeolian stratification and facies association in desert sediments, Arran basin (Permian, Scotland). Sedimentology 30, 311-339.

Clemmensen, L. B. \& Blakey, R. C. 1989: Erg deposits in the Lower Jurassic Wingate Sandstone, northern eastern Arizona: oblique dune sedimentation. Sedimentology 36, 449 470.

Clemmensen, L. B., Olsen, H. \& Blakey, R. C. 1989: Erg- margin deposits in the Lower Jurassic Moenave Formation and Wingate Sandstone, southern Utah. Bull. Geol. Soc. Am. 101, 759-773.

Coleman, J. M. 1969: Brahmaputra River: channel processes and sedimentation. Sediment. Geol. 3, 129-239.

Collinson, J. D. 1970: Bedforms of the Tana River, Norway. Geografiska Annaler 52A, 31-56.

Daniel, J. F. 1971: Channel movement of meandering Indiana streams. Prof. Pap. US geol. Surv. 732A, 18 p.

Demicco, R. V. \& Kordesh, E. G. 1986: Facies sequences of a semi-arid closed basin: the Lower Jurassic East Berlin Formation of the Hartford Basin, New England, USA. Sedimentology 33, 107-118.

Denny, C. S. 1967: Fans and pediments. Am. J. Sci. 265, 81105.

Doe, T. W. \& Dott, R. H., Jr. 1980: Genetic significance of deformed cross bedding - with examples from the Navajo and Weber sandstones of Utah. J. sedim. Petrol. 50, 793-812.

Donovan, R. N. 1980: Lacustrine cycles, fish ecology and stratigraphic zonation in the Middle Devonian of Caithness. Scott. J. Geol. 16, 35-50.

Elliott, T. 1974: Interdistributary bay sequences and their genesis. Sedimentology 21, 611-622.

Farrell, K. M. 1987: Sedimentology and facies architecture of overbank deposits of the Mississippi River, False River region, Louisiana. In Ethridge, F. G., Flores, R. M. \& Harvey, M. D. (ed.) Recent developments in fluvial sedimentology. Spec. Publ. Soc. Econ. Paleont. Miner. 39, 111-120.

Fisher, W. L. \& McGowen, J. H. 1967: Depositional systems in the Wilcox Group of Texas and their relationship to occurrence of oil and gas. Gulf Coast Assoc. Geol. Soc. Trans. 17, 105-125.

Friend, P. F. 1978: Distinctive features of some ancient river systems. In Miall, A. D. (ed.) Fluvial sedimentology. Mem. Can. Soc. Petrol. Geol. 5, 531-542.

Friend, P. F., Alexander-Marrack, P. D., Nicholson, J. \& Yeats, A. K. 1976a: Devonian sediments of East Greenland I. Introduction, classification of sequences, petrographic notes. Meddr Grønland 206(1), 56 pp.

Friend, P. F., Alexander-Marrack, P. D., Nicholson, J. \& Yeats, A. K. 1976b: Devonian sediments of East Greenland II. Sedimentary structures and fossils. Meddr Gronland 206(2), 91 pp.

Friend, P. F., Alexander-Marrack, P. D., Allen, K. C., Nicholson, J. \& Yeats, A. K. 1983: Devonian sediments of East Greenland. VI. Review of results. Meddr Gronland 206(6), 96 pp.

Frostick, L. \& Reid, I. 1987: Tectonic control of desert sediments in rift basins ancient and modern. In Frostick, L. \& Reid, I. (ed.) Desert sediments: ancient and modern. Spec. Publ. geol. Soc. Lond. 35, 53-68.

Fryberger, S. G., Ahlbrandt, T. S. \& Andrews, S. 1979: Origin, sedimentary features and significance of low angle eolian 'sandsheet' deposits, Great Sand Dunes National Monument and Vicinity, Colorado. J. sedim. Petrol. 49, 733-746.

Fryberger, S. G., Al-Sari, A. M. \& Clisham, T. J. 1983: Eolian dune, interdune, sand sheet, and siliciclastic sabkha sediments of an offshore prograding sand sea, Dhahran area, Saudi Arabia. Bull. Amer. Ass. Petrol. Geol. 63, 280-312. 
Fryberger, S. G. \& Schenk, C. J. 1988: Pin stripe lamination: a districtive feature of modern and ancient eolian sediments. Sediment. Geology 55, 1-15.

Galloway, W. E. 1989: Genetic stratigraphic sequences in basin analysis I; architecture and genesis of flooding-surface bounded depositional units. Bull. Amer. Ass. Petrol. Geol. 73, 125-142.

Glennie, K. W. 1970: Desert sedimentary environments. Developments in Sedimentology 14, 222 pp. Amsterdam: Elsevier.

Gloppen, T. G. \& Steel, R. J. 1981: The deposits, internal structure and geometry of six alluvial fan - fan-delta bodies (Devonian, Norway) - a study in the significance of bedding sequences in conglomerates. In Ethridge, F. G. (ed.) Nonmarine deposits - models for exploration. Spec. Publ. Soc. Econ. Paleont. Miner. 31, 49-69.

Halfman, J. D. \& Johnson, T. C. 1988: High-resolution record of cyclic climatic change during the past 4 ka from Lake Turkana, Kenya. Geology 16, 496-500.

Haller, J. 1970: Tectonic map of East Greenland (1:500 000). Meddr Grønland 171(5), 286 pp.

Haller, J. 1971: Geology of the East Greenland Caledonides, 415 pp. New York: Interscience Publishers.

Hardie, L. A., Smoot, J. P. \& Eugster, H. P. 1978: Saline lakes and their deposits: a sedimentological approach. In Matter, A. \& Tucker, M. E. (ed.) Modern and ancient lake sediments. Spec. Publ. Int. Ass. Sediment. 2, 7-41.

Havholm, K. G. \& Kocurek, G. 1988: A preliminary study of the dynamics of a modern draa, Algodones, southeastern California, USA. Sedimentology 35, 649-669.

Hays, J. D., Imbrie, J. \& Schackleton, N. J. 1976: Variations in the Earth's orbit: pacemaker of the ice ages. Science 194, 1121-1132.

Hein, F. J. \& Walker, R. G. 1977: Bar evolution and development of stratification in the gravelly, braided, Kicking Horse River, British Columbia. Can. J. Earth Sci. 14, 562570 .

Heward, A. P. 1978: Alluvial fan sequence and megasequence models: with examples from Westphalian D - Stephanian B coalfield, northern Spain. In Miall, A. D. (ed.) Fluvial sedimentology. Mem. Can. Soc. Petrol. Geol. 5, 669-702.

Hossack, J.R. 1984: The geometry of listric growth faults in the Devonian basins of Sunnfjord, W. Norway. J. geol. Soc. Lond. 141, 629-637.

Hubert, J. F. \& Mertz, K. A. Jr. 1983: Eolian sandstones in Upper Triassic - Lower Jurassic red beds of the Funday basin, Nova Scotia. J. sedim. Petrol. 54, 798-810.

Hunter, R. E. 1973: Pseudo-crosslamination formed by climbing adhesion ripples. J. sedim. Petrol. 43, 1125-1127.

Hunter, R. E. 1977: Basic types of stratification in small eolian dunes. Sedimentology 24, 361-387.

Hunter, R. E., Richmond, B. M. \& Alpha, T. R. 1983: Stormcontrolled oblique dunes of the Oregon coast. Bull. geol. Soc. Am. 94, 1450-1465.

Jackson, R. G. II 1975: Velocity - bed-form - texture patterns of meander bends in the lower Wabash River of Illinois and Indiana. Bull. geol. Soc. Am. 86, 1511-1522.

Jackson, R. G. II 1976: Depositional model of point bars in the Lower Wabash River. J. sedim. Petrol. 46, 579-594.
Johnson, J. G., Klapper, G. \& Sandberg, C. A. 1985: Devonian eustatic fluctuations in Euramerica. Bull. geol. Soc. Am. 96, 567-587.

Kelly, S. B. \& Olsen, H. 1993: Terminal fans - a review with reference to Devonian examples. In Fielding, C. R. (ed.) Current research in fluvial sedimentology. Sedimentary Geology 85, 339-374.

Kendall, C. G. S. C. \& Warren, J. 1987: A review of the origin and setting of tepees and their associated fabrics. Sedimentology 34, 1007-1027.

Kocurek, G. 1981a: Erg reconstruction: the Entrada Sandstone (Jurassic of northern Utah and Colorado). Palaeogeogr. Palaeoclim. Palaeoecol. 36, 125-153.

Kocurek, G. 1981b: Significance of interdune deposits and bounding surfaces in eolian dune sands. Sedimentology $\mathbf{2 8}$, 753-780.

Kocurek, G. 1986: Origins of low-angle stratification in aeolian deposits. In Nickling, W. G. (ed.) Aeolian geomorphology, Proceedings of the 17th Annual Binghamton Geomorphology Symposium, 177-193. Boston: Allen \& Unwin.

Kocurek, G. \& Dott, R. H. Jr. 1983: Jurassic palaeogeography and palaeoclimate of the central and southern Rocky Mountain region. In Reynolds, M. W. \& Dolly, E. D. (ed.) Mesozoic palaeogeography of West-Central United States. Spec. Publs Soc. Econ. Paleont. Miner. 101-116.

Kocurek, G. \& Fielder, G. 1982: Adhesion structures. J. sedim. Petrol. 52, 1229-1241.

Kocurek, G. \& Nielson, J. 1986: Conditions favourable for the formation of warm-climate aeolian sand sheets. Sedimentology 33, 795-816.

Kulling, O. 1930: Stratigraphic studies of the geology of Northeast Greenland (Preliminary report). Meddr Gronland 74(13), 317-346.

Kulling, O. 1931: An account of the localities of the Upper Devonian vertebrate finds in East Greenland in 1929. Meddr Gronland 86(2), 14 pp.

Kutzbach, J. E. \& Street-Parrot, F. A. 1985: Milankovitch forcing of fluctuations in the level of tropical lakes from 18 to 0 kyr BP. Nature, Lond. 317, 130-134.

Lancaster, N. \& Teller, J. T. 1988: Interdune deposits of the Namib Sand Sea. Sediment. Geol. 55, 91-107.

Lang, S. C. \& Fielding, C. R. 1991: Facies architecture of a Devonian soft-sediment-deformed alluvial sequence, Broken River Province, northeastern Australia. In Miall, A. D. \& Tyler, N. (ed.) The three-dimensional facies architecture of terrigenous clastic sediments and its implications for hydrocarbon discovery and recovery. Spec. Publ. Soc. Econ. Paleont. Miner., Concepts in Sedimentology and Paleontology $\mathbf{3}$, 122-132.

Larsen, H. C., Armstrong, G., Marcussen, C., Moore, S. \& Stemmerik, L. 1989: Deep seismic data from the Jameson Land basin, East Greenland. IFP/ILP/IUGS Exploration Research Conference: The potential of deep seismic profiling for hydrocarbon research, Arles, France, June 1989. Terra $A b$ stracts 1, 10-11.

Larsen, P.-H. 1990a: Geological map (1:100 000) of the Devonian basin, North-East Greenland. Unpubl. intern. GGU rep. 6 pp., 3 maps. 
Larsen, P.-H. 1990b: Geological, structural contour and isopach maps (1:50 000) of the upper Devonian Celsius Bjerg Group on eastern Gauss Halvø, North-East Greenland. Unpubl. intern. GGU rep., 6 pp., 12 maps.

Larsen, P.-H. 1990c: Structural contour and isopach maps (1:50 000) of the Upper Devonian Kap Graah Group on western Gauss Halvø, North-East Greenland. Unpubl. intern. GGU rep., 6 pp., 6 maps.

Larsen, P.-H. 1990d: The Devonian basin in East Greenland. Status of structural studies, June 1990. Unpubl. intern. GGU rep., 54 pp.

Larsen, P.-H. \& Bengaard, H.-J. 1991: The Devonian basin initiation in East Greenland: a result of sinistral wrench faulting and Caledonian extensional collapse. J. geol. Soc. Lond. 148, 355-368.

Larsen, P.-H. \& Olsen, H. 1991: The Devonian basin project, North-East Greenland - a summary. Rapp. Gronlands geol. Unders. 152, 17-20.

Larsen, P.-H., Olsen, H., Rasmussen, F. D. \& Wilken, U. G. 1989: Sedimentological and structural investigations of the Devonian basin, East Greenland. Rapp. Gronlands geol. Unders. 145, 108-113.

Lawrence, D. A. \& Rust, B. R. 1988: The Devonian clastic wedge of eastern Gaspé and the Acadian orogeny. In McMillan, N. J., Embry, A. F. \& Glass, D. J. (ed.) Devonian of the World, vol. II: Sedimentation. Mem. Can. Soc. Petrol. Geol. 14(2), 53-64.

Lawrence, D. A. \& Williams, B. P. J. 1987: Evolution of drainage systems in response to Acadian deformations: the Devonian Battery Point Formation. In Ethridge, F. G., Flores, R. M. \& Harvey, M. D. (ed.) Recent developments in fluvial sedimentology. Spec. Publ. Soc. Econ. Paleont. Miner. 39, 287-300.

Leeder, M. 1973: Sedimentology and palaeogeography of the Upper Old Red Sandstone in the Scottish Border Basin. Scott. J. Geol. 9, 117-144.

Leeder, M. R. 1975: Pedogenic carbonate and flood sediment accretion rates: a quantitative model for alluvial, arid-zone lithofacies. Geol. Mag. 112, 257-270.

Leeder, M. R. 1987: Sediment deformation structures and the palaeotectonic analysis of sedimentary basins, with a casestudy from the Carboniferous of northern England. In Jones, M. E. \& Preston, R. M. F. (ed.) Deformation of sediments and sedimentary rocks. Spec. Publ. geol. Soc. Lond. 29, 137 146.

Leopold, L. B. \& Wolman, M. G. 1957: River channel patterns: braided, meandering and straight. Prof. Pap. U.S. geol. Surv. 282B, 39-85.

Loope, D. B. 1984: Eolian origin of Upper Palaeozoic sandstones, southeastern Utah. J. sedim. Petrol. 54, 563-580.

Marcussen, C., Christiansen, F. G., Larsen, P.-H., Olsen, H., Piasecki, S., Stemmerik, L., Bojesen-Koefoed, J., Jepsen, H. F. \& Nøhr-Hansen, H. 1987: Studies of the onshore hydrocarbon potential in East Greenland 1986-87: fieldwork from $72^{\circ}-74^{\circ}$ N. Rapp. Gronlands geol. Unders. 135, 72-81.

Marcussen, C., Larsen, P.-H., Nøhr-Hansen, H., Olsen, H., Piasecki, S. \& Stemmerik, L. 1988: Studies of the onshore hydrocarbon potential in East Greenland 1986-87: fieldwork from $73^{\circ}$ to $76^{\circ} \mathrm{N}$. Rapp. Gronlands geol. Unders. 140 , 89-95.

Massari, F. 1983: Tabular cross-bedding in Messinian fluvial channel conglomerates, southern Alps, Italy. In Jollinson, J. D. \& Lewin, J. (ed.) Modern and ancient fluvial systems. Spec. Publ. Int. Assoc. Sediment. 6, 287-300.

McClay, K. T., Norton, G. M., Coney, P., Davis, G. H. 1986: Collapse of the Caledonian orogen and the Old Red Sandstone. Nature, Lond. 323, 147-149.

McKee, E. D., Couglass, J. R. \& Rittenhouse, S. 1971: Deformation of lee-side laminae in eolian dunes. Bull. geol. Soc. Am. 82, 359-378.

Miall, A. D. 1981: Alluvial sedimentary basins: tectonic setting and basin architecture. In Miall, A. D. (ed.) Sedimentation and tectonics in alluvial basins. Spec. Pap. geol. Assoc. Can. 23, 1-33.

Miall, A. D. 1984: Principles of sedimentary basin analyses, 490 pp. New York: Springer Verlag.

Miall, A. D. 1985: Architectural-element analysis: A new method of facies analysis applied to fluvial deposits. EarthScience Reviews 22, 261-308.

Miall, A. D. 1990: Principles of sedimentary basin analyses, 668 pp. Second edition. New York: Springer Verlag.

Moody-Stuart, M. 1966: High and low-sinuosity stream deposits, with examples from the Devonian of Spitsbergen. $J$. sedim. Petrol. 36, 1102-1117.

Nicholson, J. \& Friend, P. F. 1976: Devonian sediments of East Greenland. V. The central sequence, Kap Graah Group and Mount Celsius Supergroup. Meddr Grønland 206(5), 117 pp.

Nilsen, T.H. 1973: Devonian (Old Red Sandstone) sedimentation and tectonics of Norway. In Pitcher, M. G. (ed.) Arctic geology. Mem. Am. Ass. Petrol. Geol. 19, 471-481.

Norton, G. M., McClay, K. R., Way, N. A. 1987: Tectonic evolution of Devonian basins in northern Scotland and southern Norway. Norsk geol. Tidsskr. 67, 323-338.

Olsen, H. 1989: Sandstone-body structures and ephemeral stream processes in the Dinosaur Canyon Member, Moenave Formation (Lower Jurassic), Utah, USA. Sediment. Geol. 61, 207-221.

Olsen, H. 1990: Astronomical forcing of meandering river behaviour: Milankovitch cycles in Devonian of East Greenland. Palaeogeogr. Palaeoclim. Palaeoecol. 79, 99-115.

Olsen, H. 1993: Orbital forcing on continental depositional systems - lacustrine and fluvial cyclicity in the Devonian of East Greenland. In de Boer, P. L. \& Smith, D. G. (ed.) Orbital forcing and cyclic sequences. Spec. Publ. Int. Ass. Sediment.

Olsen, H., Due, P. H. \& Clemmensen, L. B. 1989: Morphology and genesis of asymmetric adhesion warts - a new adhesion surface structure. Sediment. Geology 61, 277-285.

Olsen, H. \& Larsen, P.-H. 1993a: Lithostratigraphy of the continental Devonian sediments in North-East Greenland. Bull. Gronlands geol Unders. 165, 108 pp.

Olsen, H. \& Larsen, P.-H. 1993b: Structural and climatic controls on fluvial depositional systems - Devonian, North-East Greenland. In Marzo, M. \& Puigdefàbregas, C. (ed.) Alluvial sedimentation. Spec. Publ. Int. Ass. Sediment. 17, 401-423.

Parkash, B., Awasthi, A. K. \& Gohain, K. 1983: Lithofacies of 
the Markanda terminal fan, Kurukshetra district, Haryana, India. In Collinson, J. E. \& Lewin, J. (ed.) Modern and ancient fluvial systems. Spec. Publ. Int. Ass. Sediment. 6, 337-344.

Picard, M. D. \& High, L. R., Jr. 1973: Sedimentary structures of ephemeral streams. Developments in sedimentology 17, 223 pp. Amsterdam: Elsevier.

Press, F. \& Siever, R. 1974: Earth, 649 pp.. San Fransisco: W. H. Freeman and company.

Puigdefabregas, C. 1973: Miocene point-bar deposits in the Ebro Basin, northern Spain. Sedimentology 20, 133-144.

Puigdefabregas, C. \& van Vliet, A. 1978: Meandering stream deposits from the Tertiary of the southern Pyrenees. In Miall, A. D. (ed.) Fluvial sedimentology. Mem. Can. Soc. Petrol. Geol. 5, 469-486.

Raaf, J. F. M. de, Boersma, J. R. \& Gleder, A. van 1977: Wave-generated structures and sequences from a shallow marine succession, Lower Carboniferous, County Cork, Ireland. Sedimentology 24, 451-483.

Ramos, A. \& Sopena, A. 1983: Gravel bars in low-sinuosity streams (Permian and Triassic, central Spain). In Collinson, J. D. \& Lewin, J. (ed.) Modern and ancient fluvial systems. Spec. Publ. Int. Ass. Sediment. 6, 301-312.

Reineck, H.-E. \& Singh, I. B. 1980: Depositional sedimentary environments, with reference to terrigenous clastics, 549 pp. Berlin: Springer Verlag.

Ross, G. M. 1983: Bigbear erg: a Proterozoic intermontane eolian sand sea in the Hornby Bay Group, Northwest Territories, Canada. In Brookfield, M. E. \& Ahlbrandt, T. S. (ed.) Eolian sediments and processes. Developments in Sedimentoloty 38, 483-519. Amsterdam: Elsevier.

Rubin, D. M. \& Hunter, R. E. 1983: Reconstructing bedform assemblages from compound crossbedding. In Brookfield, M. E. \& Ahlbrandt, T. S. (ed.) Eolian sediments and processes. Developments in Sedimentology 38, 407-427. Amsterdam: Elsevier.

Rubin, D. M. \& Hunter, R. W. 1985: Why deposits of longitudinal dunes are rarely recognized in the geological record. Sedimentology 32, 147-157.

Rubin, D. M. 1987: Cross-bedding, bedforms, and paleocurrents. Soc. Econ. Paleont. Miner., Concepts in Sedimentology and Paleontology 1, $187 \mathrm{pp}$.

Rust, B. R. 1972: Structure and process in a braided river. Sedimentology 18, 221-245.

Rust, B. R. 1978: Depositional models for braided alluvium. In Miall, A. D. (ed.) Fluvial sedimentology. Mem. Can. Soc. Petrol. Geol. 5, 605-625.

Rust, B. R. 1979: Facies Models 2. Coarse alluvial deposits. In Walker, R. G. (ed.) Facies models. Geoscience Canada, Reprint Series 1, 9-21.

Rust, B. R. \& Nanson, G. C. 1989: Bedload transport of mud as pedogenic aggregates in modern and ancient rivers. Sedimentology 36, 291-306.

Schenk, C. J. \& Fryberger, S. G. 1988: Early diagenesis of eolian dune and interdune sands at White Sands, New Mexico. Sediment. Geol. 55, 109-120.

Schumm, S. A. 1968: Speculations concerning paleohydrologic controls of terrestrial sedimentation. Bull. geol. Soc. Am. 79, 1578-1588.

Schumm, S. A. 1981: Evolution and response of the fluvial system, sedimentologic implications. In Ethridge, F. G. \& Flores, R. M. (ed.) Recent and ancient nonmarine depositional environments, models for exploration. Spec. Publ. Soc. Econ. Paleont. Miner. 31, 19-29.

Schumm, S. A. \& Khan, H. R. 1972: Experimental study of channel patterns. Bull. geol. Soc. Am. 83, 1755-1770.

Séguret, M., Séranne, M., Chauvet, A. \& Brunel, M. 1989: Collapse basin: a new type of extensional sedimentary basin from the Devonian of Norway. Geology 17, 127-130.

Shepherd, R. G. 1987: Lateral accretion surfaces in ephemeralstream point bars. Rio Puerco, New Mexico. In Ethridge, F. G., Flores, R. M. \& Harvey, M. D. (ed.) Recent developments in fluvial sedimentology. Spec. Publ. Soc. Econ. Paleont. Miner. 39, 93-98.

Simpson, E. L. \& Loope, D. B. 1985: Amalgamated interdune deposits, White Sands, New Mexico. J. sedim. Petrol. 55, 361-365.

Singh, H., Parkash, B. \& Gohain, K 1993: Facies analysis of the Kosi megafan deposits. In Fielding, C. R. (ed.) Current research in fluvial sedimentology. Sedimentary Geology 85, 87-113.

Smith, A. G., Hurley, A. M. \& Briden, J. C. 1981: Phanerozoic paleocontinental world maps. Cambridge University Press.

Smith, N. D. 1970: The braided stream depositional environment: Comparison of the Platte River with some Silurian clastic rocks, north-central Appalachians. Bull. geol. Soc. Am. 81, 2992-3014.

Smith, N. D. 1971: Transverse bars and braiding in the lower Platte River, Nebraska. Bull. geol. Soc. Am. 82, 3407-3420.

Smith, N. D. 1974: Sedimentology and bar formation in the Upper Kicking Horse River, a braided outwash stream. J. Geol. 82, 205-224.

Smoot, J. P. 1981: Subaerial exposure criteria in modern playa and mud cracks (abstract). Bull. Am. Ass. Petrol. Geol. 65, 994 only.

Steel, R. J. 1976: Devonian basins of western Norway; Sedimentary response to tectonism and varying tectonic context. Tectonophysics 36, 207-224.

Steel, R. J. \& Aasheim, S. 1978: Alluvial sand deposition in a rapidly subsiding basin (Devonian, Norway). In Miall, A. D. (ed.) Fluvial sedimentology. Mem. Can. Soc. Petrol. Geol. 5, 385-413.

Steel, R. J. \& Gloppen, T. G. 1980: Late Caledonian (Devonian) basin formation, western Norway - signs of strike-slip tectonics during infilling. In Reading, H. \& Ballance, P. F. (ed.) Sedimentation in oblique-slip mobile zones. Spec. Publ. Int. Ass. Sediment. 4, 79-103.

Steel, R. J. \& Wilson, A. C. 1975: Sedimentation and tectonism (?Permian-Triassic) on the margin of the North Minch Basin. J. geol. Soc. Lond. 131, 183-202.

Steinmetz, R. 1967: Depositional history, primary sedimentary structures, cross bed dips, and grain size of an Arkansas river point bar at Wekiwa, Oklahoma. Rep. pan-Am. Petrol. Corp. Res. Dep., F67-G-3. 
Stensiö, E. A. 1931: Upper Devonian vertebrates from East Greenland, collected by the Danish Greenland Expeditions in 1929 and 1930. Meddr Gronland 86(1), 212 pp.

Stensiö, E. A. 1934: On the Placodermi of the Upper Devonian of East Greenland. I. Phyllolepida and Arthrodira. Meddr Gronland $97(1), 58$ pp.

Stensiö, E. A. 1940: Über die Fische des Devons von Ostgrönland. Mitt. naturf. Ges. Schaffhausen 16, 132-137.

Sweet, M. L., Nielson, J. M., Havholm, K. \& Faralley, J. 1988: Algodones dune field of southeastern California: case history of a migrating modern dune field. Sedimentology 36, 939952.

Sweet, M. L. \& Kocurek, G. 1990: An empirical model of aeolian dune lee-face airflow. Sedimentology 37, 1023-1038.

Säve-Sönderbergh, G. 1932a: Notes on the Devonian stratigraphy of East Greenland. Meddr Grønland 94(4), 40 pp.

Säve-Sönderbergh, G. 1932b: Preliminary note on Devonian Stegocephalians from East Greenland. Meddr Grønland 94 (7), $107 \mathrm{pp}$.

Säve-Sönderbergh, G. 1933: Further contributions to the Devonian stratigraphy of East Greenland, I. Results from the summer expedition 1932. Meddr Grønland 96(1), 40 pp.

Säve-Sönderbergh, G. 1934: Further contributions to the Devonian stratigraphy of East Greenland, II. Investigations on Gauss Peninsula during the summer of 1933. With an appendix: Notes on the geology of the Passage Hills (East Greenland). Meddr Gronland 96(2), 74 pp.

Säve-Sönderbergh, G. 1935: On the dermal bones of the head in Labyrinthodont Stegocephalians and primitive reptilia, with special reference to Eotriassic Stegocephalians from East Greenland. Meddr Gronland 98(3), 211 pp.
Tunbridge, I. P. 1981: Sandy high-energy flood sedimentation some criteria for recognition, with an example from the Devonian of S.W. England. Sediment. Geol. 28, 79-95.

Tunbridge, I. P. 1984: Facies model for a sandy ephemeral stream and clay playa complex; the Middle Devonian Trontishoe Formation of North Devon, U.K. Sedimentology 31, 697-715.

Van der Voo, R. 1988: Paleozoic paleogeography of North America, Gondwana, and intervening displaced terranes: Comparisons of paleomagnetism with paleoclimatology and biogeographical patterns. Bull. geol. Soc. Am. 100, 311-324.

Williams, G. E. 1970: Piedmont sedimentation and late Quaternary chronology in the Biskra region of northern Sahara. Zeits. Geomorphologie, Supplement Band 10, 40-63.

Williams, G. E. 1971: Flood deposits of the sand-bed ephemeral streams of central Australia. Sedimentology 17, 1-40.

Woodward, A.S. 1890: Notes on some Devonian fish-remains, discovered by Prof. A.G. Nathorst in East Greenland. Bih. K. Svenska Vetensk.-Akad. Handl. 26(4), 10 pp.

Wright, V.P., Platt, N.H. \& Wimbledon, W.A. 1988: Biogenic laminar calcretes: evidence of calcified root-mat horizons in paleosols. Sedimentology 35, 603-620.

Yeats, A. K. \& Friend, P. F. 1978: Devonian sediments of East Greenland. IV. The western sequence, Kap Kolthoff Supergroup of the western areas. Meddr Gronland 206(4), 112 pp.

Ziegler, P. A. 1988: Laurussia - the Old Red Continent. In McMillan, N. J., Embry, A. F. \& Glass, D. J. (ed.) Devonian of the World, vol. I: Regional syntheses. Mem. Can. Soc. Petrol. Geol. 14(1), 15-48. 